B O N N E V I L L E P O W E R A D M I N I S T R A T I O Yakima River Species Interactions Studies

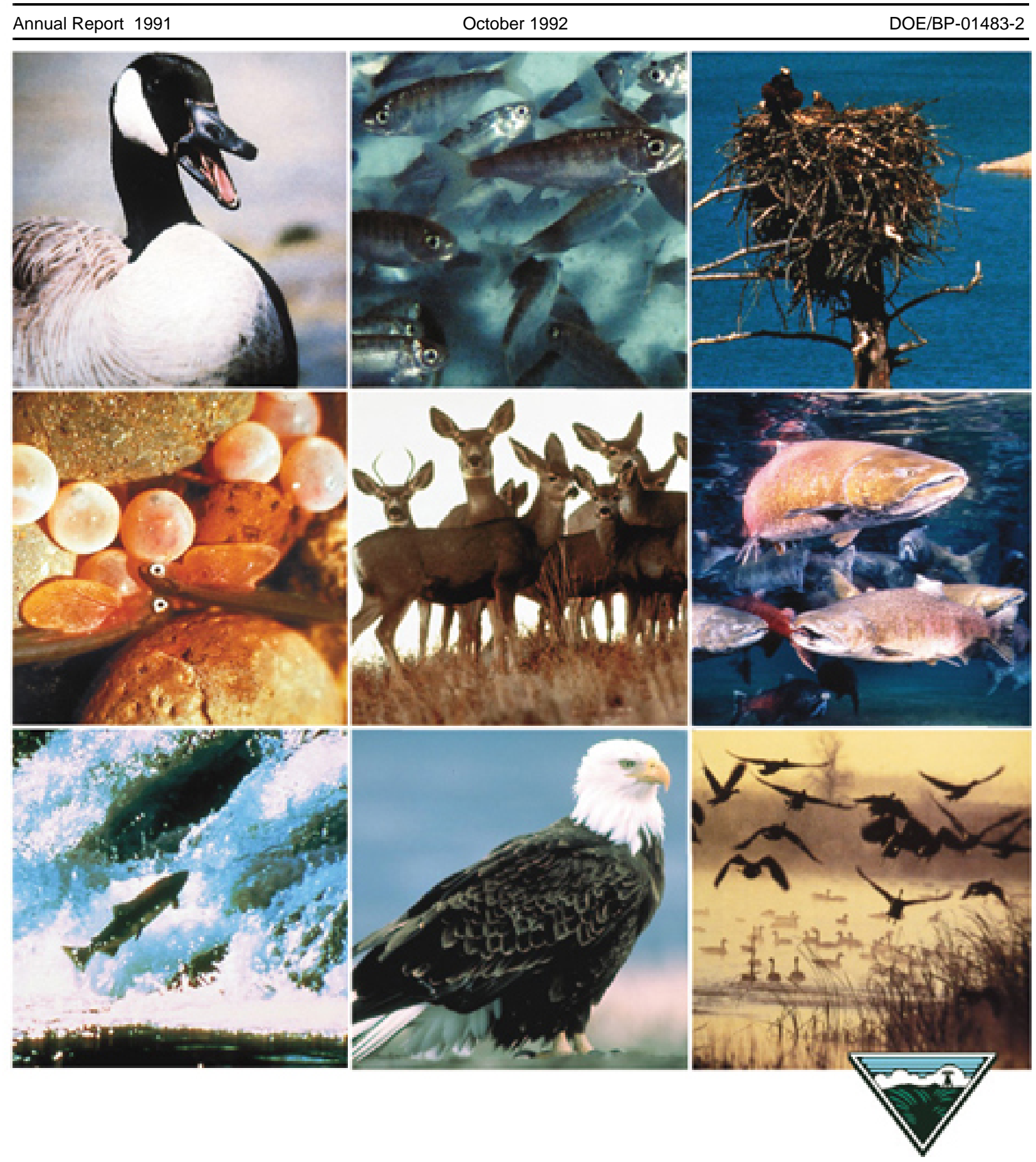


This Document should be cited as follows:

McMichael, Geoffrey, James Olsen, Eric Bartrand, Naraia Fischer, James Hindman, Steven

Leider, "Yakima River Species Interactions Studies", 1991 Annual Report, Project No.

198910500, 194 electronic pages, (BPA Report DOE/BP-01483-2)

\author{
Bonneville Power Administration \\ P.O. Box 3621 \\ Portland, OR 97208
}

This report was funded by the Bonneville Power Administration (BPA), U.S. Department of Energy, as part of BPA's program to protect, mitigate, and enhance fish and wildlife affected by the development and operation of hydroelectric facilities on the Columbia River and its tributaries. The views in this report are the author's and do not necessarily represent the views of BPA. 
YARIMA RIVER SPECIES INTERACTIONS STUDIES

Annual Report FY 1991

\author{
Prepared by \\ Geoffrey A. Maxichael \\ James P. Olson \\ Eric? L. Bartrand \\ Naraia P1scher \\ James $N$. Hindman \\ Steven A. Leider
}

Washington Department of Wildlife

$$
\text { Prepared for }
$$

Tom Clune, Project Manager

U.S. Department of Energy

Bonneville Power Administration

Division of Fish and Wildlife

P.O. Box 3621

Portland, Oregon 97208-3621

Project No. 89-105

Agreement No. DE-BI79-89BP01483

October 1992 


\section{EXECUTIVE SUMARY}

The Yakima/Klickitat Fisheries Project (YKFP) proposes to assess the merits of "supplementation" as a means to increase natural production and harvest opportunities for anadromous fish in the Yakima and Klickitat subbasins. Supplementation involves rearing and release of artificially produced fish, which upon. return as adults, would be managed to form a major component of the naturally spawning population.

In late 1989, studies of species interactions were implemented to address concerns about the possible adverse effects of the Yakima Fisheries Project ((YFP) the Yakima portion of the EKFP) on resident trout populations in the upper Yakima 'River basin. Resident trout in this area-contribute to a high quality sport. fishery of special importance to the state. The initial study objective involved collection of baseline information on resident trout in the upper Yakima River and its associated tributaries; regarding spawning and rearing distributions, densities, and biological and genetic profiles of resident fish populations. Work on a second major objective was initiated in the spring of 1991 to investigate the outcome of specific interactions between hatchery steelhead smolts and resident trout. It should be emphasized that the hatchery steelhead used for this part of our interactions research may not have been representative-of the actual products expected from the YFP. However, results from this line of investigation should provide information useful for development of assessment and long-term monitoring methods, and 
should also contribute toward an underetanding of important interactions under existing conditions. The ultimate goal of this research is to develop a long-term plan to monitor species. interactions after implementation of the YFP.

This report addresses activities conducted from July 1,1990 to December 31, 1991. Results should be considered preliminary, subject-to change upon completion of the stidy.

Baseline data were collected using a variety of techniques. : Electroflshing and snorkeling were the primary methods used, hook and line andtrapping methods were also applied occasionally:

Blological data (e.g. species, length, weight) were collected for all salmonids captured by electrofishing. A.total of $2,720 \%$ resident trout were tagged and released in 1991 to investigate movement of fish within the- study area and to analyze growth rates of individual fish.' A total of 734 rainbow trout were collected.from different locations-within the study area for genetic analysis (protein electrophoresis) of population structure and ancestry (hatcheryfwild). Scales from these trout were analyzed for stock fdentfficatian as well ast to determine: individual fish ages.

Rainbow trout spawned from late February through late May of 1991. Spawning- generally occurted earller in lower elevation areas and-later in the upper areas of tributaries and the "... mainstem Yakima River. The greatest densities of large spawning rainbow trout occurred in the lower mainstem Yakima River and its low elevation tributaries (i.e. Umtanum, Cherry, and w11son -- 
creeks). Higher elevation tributaries and mainstem areas contained fewer and smaller trout.. It was in these high elevation areas that most of the few anadromous fish (steelhead. and spring chinook salmon) within the study area are known to currently spawn. Preliminary analysis of the data indicated that very few of the large resident rainbow trout utilized the upper elevation tributaries and mainstem areas for the purpose of spawning.

Summer and fall rearing surveys indicated salmonid densities and species composition were very different between sites and between years. Lineal densities of rainbow trout in tributaries ranged from 11 to 114 fish/100 m. For all sections pooled, results showed an $8.8 \%$ increase in biomass (grams of $\mathrm{fish} / \mathrm{m}^{2}$ ) from 1990 to 1991. Juvenile spring chinook salmon were abundant in the lower portions of several tributaries in 1990 but were virtually absent in 1991. Physical habitat in tributary sites changed between years. Pool habitat decreased between 1990 and 1991.

Rainbow trout population estimates were conducted in five mainstem Yakima River sections below Easton Dam. Results. indicated density decreased from a range of 413 to 765 trout/ka in 1990 to 274 to 314 trout $/ \mathrm{km}$ in 1991. Possible factors for this apparent decrease are discussed.;

Relative abundance surveys were initiated in 1991 to document the general distribution and relative densities of all fish species in ten tributaries of the upper Yakima River. Rainbow 
trout generally were more abundant than cutthroat trout in lower sections within a tributary, while the reverse was true in the upper elevation areas. Scuplins and dace were 'collected in most study' sections of all sampled streams.

'Data on movement of tagged rainbow trout suggested that seasonal'or annual movement was limited within the study areat. However, some movement was documented between lower elevation tributaries and the mainstem Yakima River. Information on relative'rainbow trout growth (from tagged individuals) showed high growth rates in Wilson Creek and portions of the Yakima River mainstem and slower growth for fish captured in upper elevation tributaries where water' temperature6 were generally cooler.

Considerable genetic variation was detected within and anong: the trout populations sampled. 'Three general population clusters were identified. The lower mainstem Yakima River and tributarles below Ellensburg comprised one cluster. The second cluster consisted of the mid-elevation tributaries (having minimal apparent exchange with the mainstem). The mainstem above Easton Dam and two tributaries in that area formed the third cluster. The incidence of hatchery ancestry was most evident in populations forming the first cluster.

In 1991, interactions between hatchery steelhedd and resident trout wore observed following the experimental release of approximately 31,500 hatchery steelhead smolts into Jungle Creek (a tributary of the North Fork of the Teanaway River) in a manner 
intended to roughly simulate volitional release from a generic YFP acclimation facility. Outmigrating fishes were captured in a traversing fyke net in the North Fork of the Teanaway River, and total numbers emigrating were estimated. Population estimates were conducted in index sites using electrofishing methods before and after the releases. Similarly, underwater observations of fish behavior were performed in index sites throughout the North Fork of the Teanaway River before and after smolt releases.

Residualism of hatchery steelhead was high in the North Fork of the Teanaway. Hatchery steelhead dispersed widely throughout the North Fork system, both up and downstream. Hatchery steelhead smolts were found in bull and cutthroat trout habitat approximately five months after they were released. Behavioral observations indicated residual hatchery steelhead were more aggressive and dominant than wild resident trout when both wild and hatchery fish were involved. Many male residual hatchery steelhead were sexually mature at the time resident trout typically spawn. Both residual hatchery steelhead and resident trout in Jungle Creek were observed with fungal infections (Sap-olegnia) several weeks after the releases. Fungal infections were not observed on fish sampled or observed outside the North Fork of the Teanaway watershed. Anglers exploited the residual hatchery steelhead to a great extent. Hatchery steelhead smolts and resident trout consumed similar food items. 


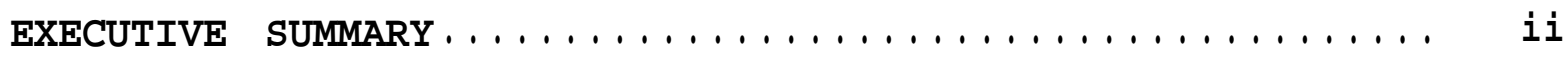

TABLE OF CONTENTS ........................... vii

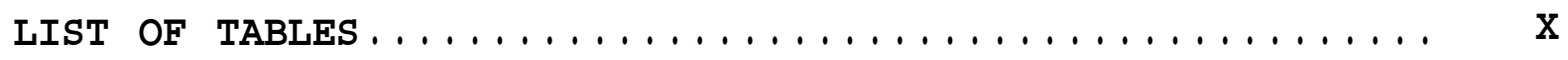

LIST OF FIGURES $\ldots \ldots \ldots \ldots \ldots \ldots \ldots \ldots \ldots \ldots \ldots \ldots \ldots \ldots \ldots \ldots \ldots$

IN TROD UCTIO.N $\ldots \ldots \ldots \ldots \ldots \ldots \ldots \ldots \ldots \ldots \ldots \ldots \ldots \ldots$

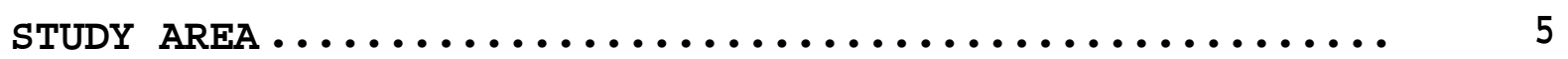

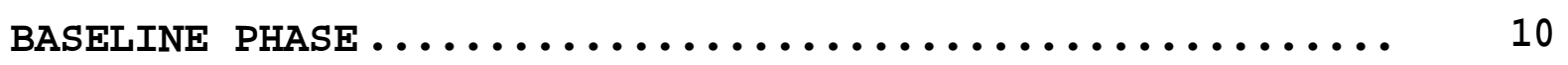

Spawning surveys $\ldots \ldots \ldots \ldots \ldots \ldots \ldots \ldots \ldots \ldots \ldots$

Methods ............................ 10

Tributaries ....................... 10

Mainstem Yakima River ................. 15

Results and Discussion ................. 17

Tributaries ........................ 17

Umtanum Creek 17

Badger Creek ...................... 24

Cherry Creek ...................... 27

Wilson Creek ....................... 29

Manastash Creek

Taneum Creek ..................... 32

Swauk Creek ....................... 35

Lower Teanaway River............... 36

West Fork Teanaway ................. 38

Middle Fork Teanaway ............... 39

North Fork Teanaway 41

Big Creek..................... 42

Cabin Creek...................... 43

Cle Elum River ................... 44

Mainstem Yakima River................ 44

Lower Canyon (Section 1).............. 44

Upper Canyon (Section 2) .............. 46

Ellensburg (Section 3) ............. 48

Thorp (Section 4) ................ 49

Cle Elum (Section 5)................ 51

Nelson Siding (Section 6) .............. 51

Crystal Springs (Section 7) ............... 52

Spawning Survey Summary ................ 53

Tributaries ......................... 53

Mainstem Yakima River................. 54 


\section{TABLE or couresirs - continued}

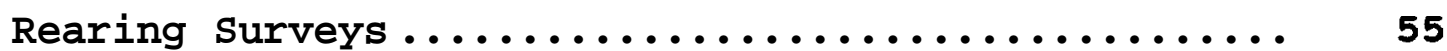

Population Estimates ................... 55

Methods .......................... 56

Tributaries ..................... 56

Mainstem Yakima River ................. 59

Results and Discussion ................. 62

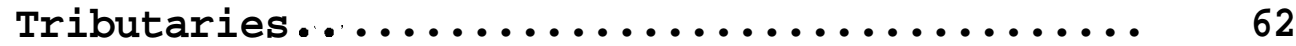

Taneum Creek ..................... 62

West Fork of the Teanaway River......... 67

Middle Fork of the Teanaway River......... 68

North Fork of the Teanaway River......... 69

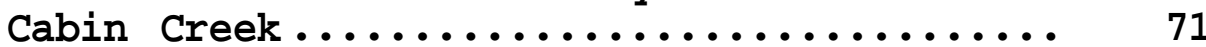

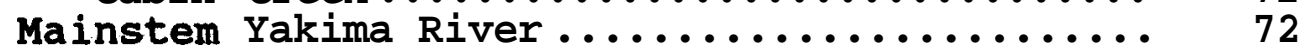

Relative Abundance Surveys .................. 77

Methods .......................... 78

Results and Discussion ................. 80

Rearing Survey summary .................. a4

Tributaries.

Mainstem Yakima -River................. 86

Relative Abundance Surveys..'............ a7

Movementand Growth ..................... 88

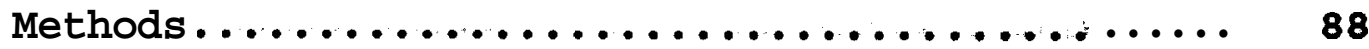

Results and Discussion ................. a9

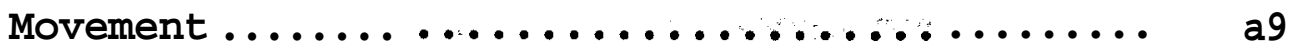

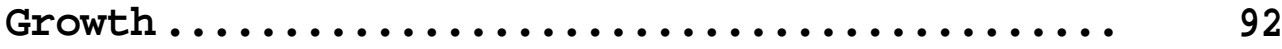

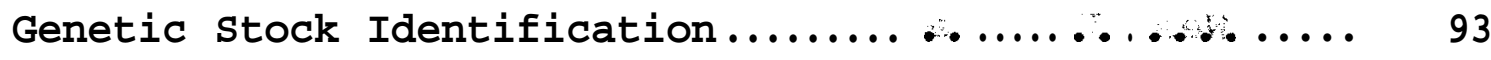

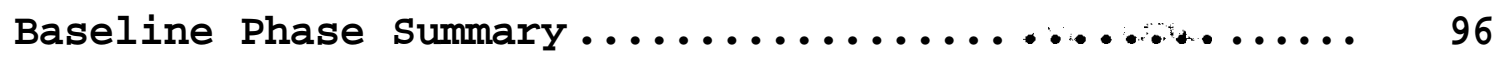

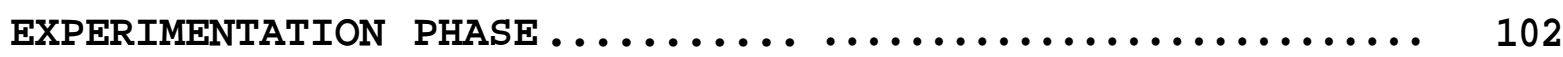

Steelhead Smolt Release study, ................. 102

Introduction ............................ 102

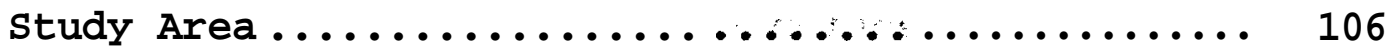

Methods .......................... 108

Test Fish Production..... 108

Experimental Releases ................. 108

Downstream Migrant Trapping................ 109

Traversing Fyke Net 109

Jungle Creek Trap.................... 109 
Roza Dam ......................... 112

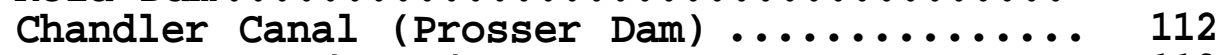

Fyke Net Calibration Releases ............ 113

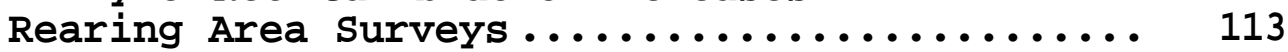

Underwater Observations .................. 114

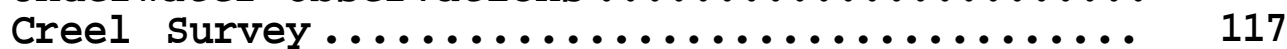

Food Utilization ..................... 117

Data Analyses ........................ 118

Downstream Migrant Enumeration ........... 118

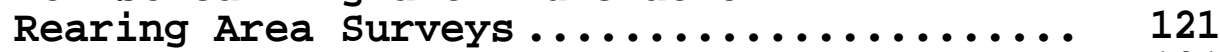

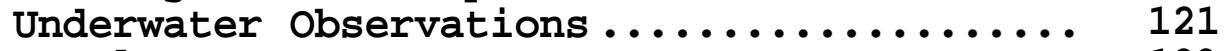

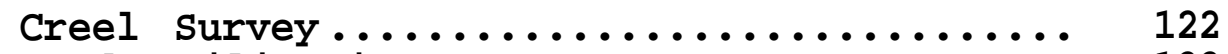

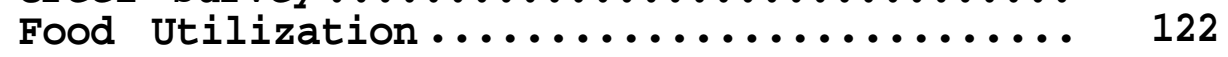

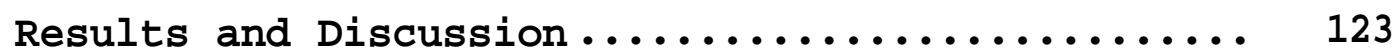

Experimental Releases ................... 123

Traversing Fyke Net Calibration Releases ..... 123

Downstream Passage ................... 125

Passage Estimates at Traversing Fyke Net... 125

Diel Movements ................... 129

Downstream Passage Timing .............. 129

Jungle Creek Downstream Trap ........... 129

North Fork of the Teanaway River........ 131

Roza Dam Juvenile Passage Facility ...... 132

Prosser Dam Juvenile Passage Facility.... 135

Downstream Passage Summary............ 138

Population Estimates ................. 140

Jungle Creek ........................ 140

North Fork of the Teanaway River.......... 141

Population Estimate Summary ............. 143

Underwater Observations ................. 144

Interactive Behaviors ................. 144

Fish Abundance Relationships Over Time..... 151

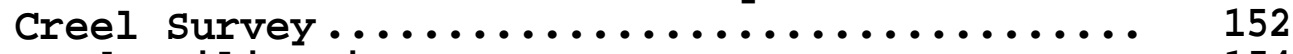

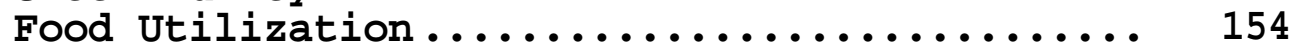

Experimentation Phase Summary.............. 159

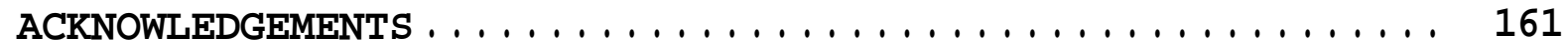

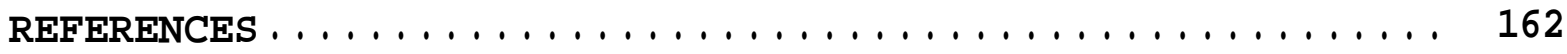

APPENDIX A. Genetic Stock Identification Report........ 166 


\section{IIBT OP TABLES}

Page

Table 1. Summary of rainbow trout captured by istream and section during 1991 spawning surveys. Sample size (N). minimum (Min), maximum (Max), and mean fork length (Mean), standard deviation (SD), average condition factor (CF), percentage of sexually mature fish, and percentage of fish that were hook-scarred. Stream sections are numbered in ascending order in an upstream direction......

Table 2. Number of fish sampled (N), mean length, mean weight, fecundity (eggs/fish), and eggs/mm of fish length for egg skeins collected from mature female rainbow trout during spawning surveys in $1991 \ldots \ldots \ldots \ldots \ldots$

Table 3. summary of rainbow trout captured in 1991 during spawning surveys of the mainstem Yakima River. Sample size (N), minimum (Min), maximum (Max), and mean length (Mean), standard deviation (SD), average condition factor (CF), percentage sexually mature (Mature), and percentage hook-scarred (Hook-scar) are presented................

Table 4. Population estimates (95\% confidence intervals), number of fish per square meter $\left(* / \mathrm{m}^{2}\right)$, biomass $\left(\mathrm{g} / \mathrm{m}^{2}\right)$, and percent species composition for 1990 and 1991 fall tributary rearing surveys.. Averaged values (MEANS) are shown for each tributary, years and sections pooled. Lower numbered sites are lower in elevation within a given tributary .............................

Table 5. Habitat measurements (percent of pool, riffle, run), water temperature $\left({ }^{\circ} \mathrm{C}\right)$ at time of-survey, total area $\left(\mathrm{m}^{2}\right)$, and flow $\left(\mathrm{m}^{3} / \mathrm{s}\right)$ for tributary population estimate sites in the upper Yakima River basin during the summer-fall periods of 1990 and 1991. Mean values (MEANS) are shown for each tributary, years and sections pooled. Lower numbered sites are lower in

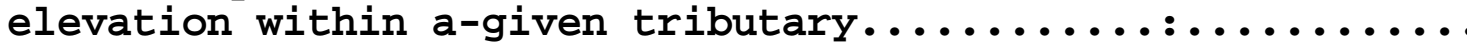

Table 6. Resident trout population estimates (with 95\% confidence intervals), biomass (kg/section), number per kilometer, kilograms per kilometer, - and mean length in millimeters of trout (Length) for five sections of the Yakima River mainstem during the falls of 1990 and 1991. Percent change (between years) for each section

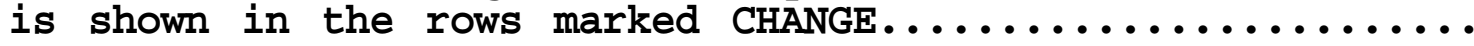


Table 7. Relative density estimates ( $/ 100 \mathrm{~m}^{2}$ ) for all species by section in five tributaries of the upper Yakima-River during fall, 1991, Abundant (abun) $=>4.0$, common (comm) $=1.4-3.9$, few $=0.1-4.3$, and none $=0$ fish per square meter $\ldots, \ldots .81$

Table 8. Physical characteristics of habitat in study--.. sites used for relative abundance surveys in tributaries. . to the upper Yakima River, fall 1991. Sample date, percentage riffle, run, pool habitat, total area, flow, and water temperature are shown for each site............

Table 9. Summary information on tagged rainbow trout reobserved in tributaries and mainstem Yakima River study sections for 1990 and 1991. Stream (or mainstem section), number of -fish recaptured (N), percentage of fish that moved a distance of $0 \mathrm{~km}$ (Zero), $0.1-4.0 \mathrm{~km}$, and more than $4.0 \mathrm{~km}$, percentage of fish: that moved from tributaries (Tribs) and mainstem -areas (Mainstem), mean number of days at 'large in 1990. (Days 90) and 1991 (Days 91), and mean growth (mm/day) of trout are shown. pooled and mean numbers are given below the tributaries (Trib Total), and mainstem sections

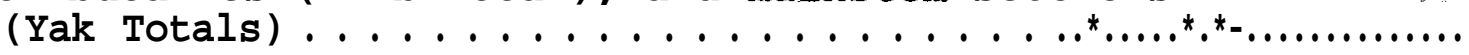

Table 10. Results of the traversing fyke net calibration releases in the North Fork of the Teanaway River during

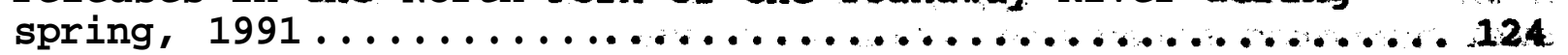

Table 11. Estimated number of salmonids migrating past the traversing fyke net in the North Fork of the Teanaway River between Hay 6 and 31,1991 . The range of estimates was based on the range of measured. capture efficiencies. Numbers calculated using a $5.0 \%$ capture efficiency are presented for purposes of discussion only

Table 12. Number and percentage: of salmonids captured during day (08:01 to 17:59 PDT) and night (18:00 to 08:00 PDT) in the North Fork Teanaway traversing fyke net April 22 through April 29 and

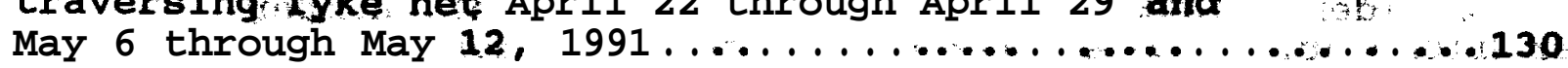


Table 13. Capture periods, sample sizes (N), mean fork lengths (mm), and mean condition factors (CF) of hatchery steelhead collected at Roza Dam during the spring and early summer of 1991 .

Table 14. Age composition, mean fork length (mm) and standard deviations (SD) of hatchery steelhead smolts captured at Prosser Dam during the spring and early summer of 1991 (data from M. Kohn, YIN, pers. comm.)...... 136

Table 15. Estimated population density, and biomass of fish sampled in Jungle Creek and the North Fork of the Teanaway River before and after the release of hatchery steelhead smolts in 1991

Table 16. Comparisons of hatchery steelhead and resident trout behavioral interactions. Behavioral interactions, defined as aggressive agnostic encounters (threats, chases, nips) or displacements (a fish being forced out of a preferred area), per fish per minute are compared to number of days after release. Data were from underwater observations in Jungle Creek and the North Fork of the Teanaway River, May 2 to September 19, 1991. The sample sizes shown for each comparison are different due to variation in behaviors occurring during each observation period $\ldots \ldots \ldots \ldots \ldots \ldots \ldots \ldots$

Table 17. Size-related dominance relationships between hatchery steelhead and resident trout in Jungle Creek and North Fork of the Teanaway River from May 2 through September 19, 1991. Number of agonistic occurrences observed (N) and the percentage of contests resulting in the corresponding dominant:subordinate relationship for each combination grouping are shown................150

Table 18. Correlations between fish observation rate (number/minute) and number of days after hatchery steelhead release for hatchery steelhead and resident trout in the North Fork of the Teanaway system from May through October, 1991. Number of sample periods (N), correlation coefficient (R), and probability values (P) are shown 


\section{II8T OF FIOURE8}

Page

Figure 1. Map of the Yakima River drainage north of the city of Yakima. Study area includes the Yakima River and its tributaries between Roza Dam and

Keechelus Dam. Mainstem Yakima River study sections $(1-7)$ are shown in circles ....................

Figure 2. Spawning timing of resident-rainbow trout in tributaries to the upper Yakima River during spawning surveys in 1991. Dots show estimated peak of spawning activity, boxes denote periods when $10 \%$ or more of the fish sampled were sexually-mature, thick lines show periods when one to nine percent of the fish were sexually mature, and thin lines cover periods when no fish in spawning condition were sampled. UMT = Umtanum $\mathrm{Cr} . \mathrm{BAD}=$ Badger $\mathrm{Cr} ., \mathrm{CHR}=$ Cherry $\mathrm{Cr}$. , WIL = Wilson $\mathrm{Cr} .$, MAN = Manastash $\mathrm{Cr} .$, TAN = Taneum Cr., SWK = Swauk Cr., WFT $=$ W. Fork Teanaway, MFT = Middle Fork Teanaway, and NFT $=\mathrm{N}$. Fork Teanaway.....

Figure 3. Length frequency histogram of rainbow trout captured in two sections of Umtanum Creek spawning. surveys in the spring, 1991.

Figure 4. Length frequency histograms of rainbow trout captured in Badger (A)., Cherry (B), and wilson (C) creeks during spawning surveys in 1991

Figure 5. Daily discharge in cubic meters per second:; (CMS) for Cherry Creek from February 1 through November 30,1991 (USBR, unpublished data) .................. 28

Figure 6. Length frequency histogram of rainbow trout captured in Manastash (A), Taneum (B), and Swauk (C) creeks during spawning surveys in $1991 \ldots \ldots \ldots \ldots \ldots \ldots \ldots . \ldots \ldots$

Figure 7. Length frequency histogram of rainbow trout captured in the West Fork (A), Middle Fork (B), and North Fork (C) of the Teanaway River during spawning

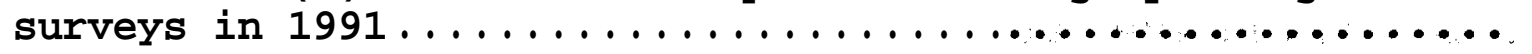




\section{LIST OF FIGUREs - continued}

Figure 8. Spawning timing of resident rainbow trout in the upper Yakima River during spawning surveys in 1991. Section numbers appear in parentheses below the corresponding section name. Dots show estimated peak of spawning activity, boxes denote perlods when ' $10 \%$ or more of the fish sampled were sexually mature, thiok lines show periods when one to nine percent of the fish were sexually mature, and thin Iines cover periods when no fish in spawning condition were 'sampled.............

Figure 9. Length frequency histograms of rainbow trout captured in Lower Canyon (A), and Upper Canyon' (B). sections of the Yakima River during spawning

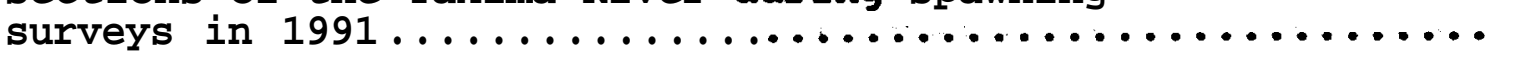

Figure 10. Length frequency histograms of rainbow trout captured in Ellensburg (A), Thorp (B), ' and Cle Elum (C), sections of the Yakima River durfhg spawrilng

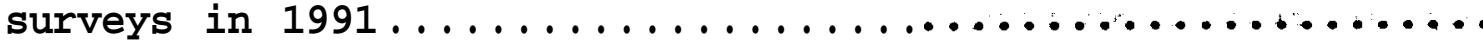

Figure 11. Length frequency distributions for mainstem

Yakima River Upper and Lower- Canyon sections pooled for fall of 1990 and 1991. Samples sizes (N) for each are shown

Figure 12. Species composition of wild-salmonids $(N=115)$ captured in the traversing fyke net operated near the mouth of the North Fork of the Teanaway River from April 22 to May 31, 1991. BUL = bull trout, $C r=$ cutthroat trout, $H Y B=$ rainbow $x$ cutthroat hybrid, $\mathrm{RBT}=$ rainbow trout, $\mathrm{SH}=$ steelhead, SPC $=$ spring chinook salmon

Figure 13. Length frequency distribution of wild rainbow trout, wild steelhead smolts, and hatchery steelhead smolts captured in a traversing fyke net operated near the mouth of the North 'Fork of the Teanaway River from

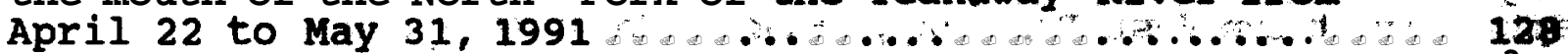

Figure 14. Cumulative daily emigration of resident trout, hatchery steelhead smolts, and wild steelhead smolts in the North Fork of the Teanaway River, from April 22 to May 31, 1991 ...................................

Figure 15. Estimated daily passage of hatchery steelhead smolts emigrating from the North Fork of the Teanaway River between April 22 and May 31, 1991............... 134 
Figure 16. Cumulative estimated passage of hatchery steelhead smolts emigrating past Prosser Dam per day from May 6 to July 10, 1991. (Data from M. Kohn, YIN,

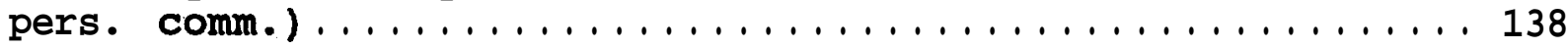

Figure 17. Number of fish observed per minute by snorkelers in Jungle Creek and the North Fork of the Teanaway River between May 2 and October 18, 1991..... 153

Figure 18. Percent by volume of various food items consumed by resident trout captured in the North Fork of the Teanaway River during the spring of 1991. MISC = unidentified items, $\mathrm{DEB}=$ debris, $\mathrm{EPH}=$ Ephemeroptera

(mayflies), PLE = Plecoptera (stoneflies), TRI = Tricoptera (caddisflies), HYM = Hymenoptera (ants and bees), COL = Coleoptera (beetles), HEM/HOM = Hemiptera (true bugs) /Homoptera (leaf hoppers), WORM = Oligochaetes (earthworms). (Data from S. Urakawa, CWU, pers. comm.)............... 156

Figure 19. Percent by volume of various food items consumed by wild steelhead captured in the North Fork of the Teanaway River during the spring of 1991 . MISC = unidentified items, DEB = debris, EPH = Ephemeroptera (mayflies), PLE = Plecoptera (stoneflies), TRI = Tricoptera (caddisflies), HYM = Hymenoptera (ants and bees), COL = Coleoptera (beetles), DIP $=$ Dipterans (midges), WORM = Oligochaetes (earthworms).

(Data from S. Urakawa, CWU, pers. comm.) .............. 157

Figure 20. Percent by volume of various food items consumed by hatchery steelhead captured in the North Fork of the Teanaway River during the spring of 1991. MISC = unidentified items, $\mathrm{DEB}=$ debris, $\mathrm{EPH}=$ Ephemeroptera

(mayflies), PLE = Plecoptera (stoneflies), TRI = Tricoptera (caddisflies), HYM = Hymenoptera (ants and bees), COL = Coleoptera (beetles), HEM/HOM = Hemiptera (true bugs) /Homoptera (leaf hoppers), DIP = Dipterans (midges), WORM = Oligochaetes (earthworms). (Data from S. Urakawa, CWU, pers. comm.) 


\section{INTRODUCTION}

In its Columbia Basin Fish and Wildlife Program, the Northwest Power Planning Council (NPPC) recognized the need and opportunity to improve natural runs of anadromous salmonids in the Yakima River basin (NPPC 1987, section 800). A primary component of this restorative effort involves the planning, design, and implementation of central outplanting facilities, termed the Yakima Fisheries Project (YFP). The intent of production from this facility will be to increase the abundance of naturally reproducing anadromous salmonids (supplementation) and to provide fish for harvest purposes, while not adversely impacting the biological or genetic resources of affected stocks (Section 703 (f) (3)). The YFP is also expected to provide a major opportunity for evaluation of supplementation success and for learning of its effects on coexisting supplemented and unsupplemented stocks.

The resident trout populations inhabiting the upper Yakima River presently provide. one of the best resident trout stream fishing opportunities in Washington State. The possibility exists that these resident trout populations will be adversely affected by biotic interactions such as competition, with released or natural fish produced from the YFP. The uncertainty and sensitivity of potential impacts of the YFP on resident fish in the upper Yakima River were identified in the Experimental Design Plan of the Yakima/Klickitat Production Project 
Preliminary Design Report (BPA 1990a). Therefore, to address this uncertainty an investigation of species interactions was initiated by the Washington Department of Wildlife (WDW) in September.of 1989, funded by the Bonneville Power Administration (BPA) .

The overall goal of current species interactions research is to investigate possible impacts of YFP activities in the upper Yakima River on resident salmonids. Species of concern include rainbow trout (Oncorhynchus mykiss), steelhead trout (anadromous form of 0 . mykiss), and chinook salmon (0. tshawytscha). Research initiatives are expected to progress in three phases: baseline data collection (pre-facility monitoring), pre-facility experimentation, and post-facility monitoring.

Baseline data are collected to document the status of resident trout populations in the upper Yakima basin prior to supplementation. Variables to be monitored are; when and where trout spawn, and the distribution, abundance, movement, and genetic profiles of resident trout and other fishes in the mainstem Yakima River and its tributaries. The data collected during the baseline phase will account for some natural variation and will be useful for comparisons following the initiation of YFP supplementation activities.

Pre-facility experimentation will be used to investigate potential impacts of supplementation (in particular, the release of hatchery-reared smolts into the natural environment) on resident trout and other fishes. Information from these 
activities will identify areas of concern in terms of what ecological impacts may be expected. This phase will also produce insight that may be used to reduce or avoid negative influences on resident fish due to YFP supplementation.

General objectives for each study phase include:

1. Baseline data collection

Conduct baseline studies to ascertain the distribution, population status, genetic structure, and life history characteristics of resident trout, steelhead, and spring chinook salmon prior to YFP supplementation activities.

2. Pre-facility experimentation

Design and conduct experiments to investigate interactions between resident trout and anadromous salmonids to assess potential impacts prior to implementation of YFP supplementation activities.

3. Post-facility monitoring

Monitor and assess the status of resident trout, steelhead, and spring chinook salmon populations after implementation of YFP supplementation.

This progress report is the second since studies began in 1989, and contains information developed from research activities conducted from July 1990 through December 1991. Because this report covers work in progress, all results should be considered preliminary. Specific objectives for work conducted during this time were as follows (objectives denoted as New were initiated since the last progress report and Cont. were initiated in 198990) : 


\section{BASELINE PHASE :}

\section{Spawning Surveys;}

$c \ldots t$ Determine the timing and distribution of resident trout spawning activity in the mainstem Yakima River and in major tributaries.

cont. Collect biological data from a representative sample of spawning resident trout populations to determine agecomposition, length-at-age characteristics, sex ratios, and growth rates.

\section{Rearing Surveys :}

New Investigate the general distribution and abundance of resident trout and other fishes residing in the mainstem Yakima River above Roza Dam and in major tributaries to obtain information on species composition, size and age class structure, and general spatial and temporal distribution patterns.

Movement and Growth:

cont. Investigate seasonal distribution and movement patterns of adult salmonids via tag returns and recaptures of tagged individuals.

Genetic Stock Identification/Scale Pattern Analysis:

Cont. Obtain samples to perform genetic assessment of resident trout population structure, ancestry, and distinctiveness from Yakima River steelhead trout.

\section{EXPERIMENTAL PHASE :}

New Assess potential impacts of hatchery steelhead smolt releases on resident trout by designing experiments to examine interactions between hatchery and wild fish such as displacement, movement, behavior, interbreeding, and 'food habits. 
STUDY AREA

The Yakima River originates in the Cascade Mountains of central Washington above Keechelus Lake (elevation $767 \mathrm{~m}$ ). As the river flows southeast to its confluence with the Columbia River, it passes through climatic transitions ranging from cool and moist in the mountains to arid in the Yakima Valley. Annual precipitation at the headwaters ranges from 200 to $350 \mathrm{~cm}$ decreasing to less than $19 \mathrm{~cm}$ in the lower reaches (Fast et al. 1989) .

This study is being conducted on the Yakima River 'and its tributaries in Kittitas County, Washington. The study area is located between Roza Dam at river kilometer ( $\mathrm{rkm}$ ) 180 and Keechelus Dam at rkm 305. It includes all major and many minor tributaries within this area (Figure 1). The study is confined to areas accessible to anadromous salmonids (i.e. areas below obstructions that form barriers to passage of upstream migrating salmon and steelhead).

The upper boundary of the study area is at the base of Keechelus Dam, one of four regulated reservoirs (Keechelus, Kachess, Easton, and Cle Elum) in the upper Yakima drainage that provide irrigation water to the Kittitas and Yakima valleys. These reservoirs greatly affect instream flow within the Yakima River. Big and Cabin creeks, and the Cle Elum River are tributaries in this upper area. Flow in the Cle Elum River fluctuates greatly as water is released for irrigation needs. 


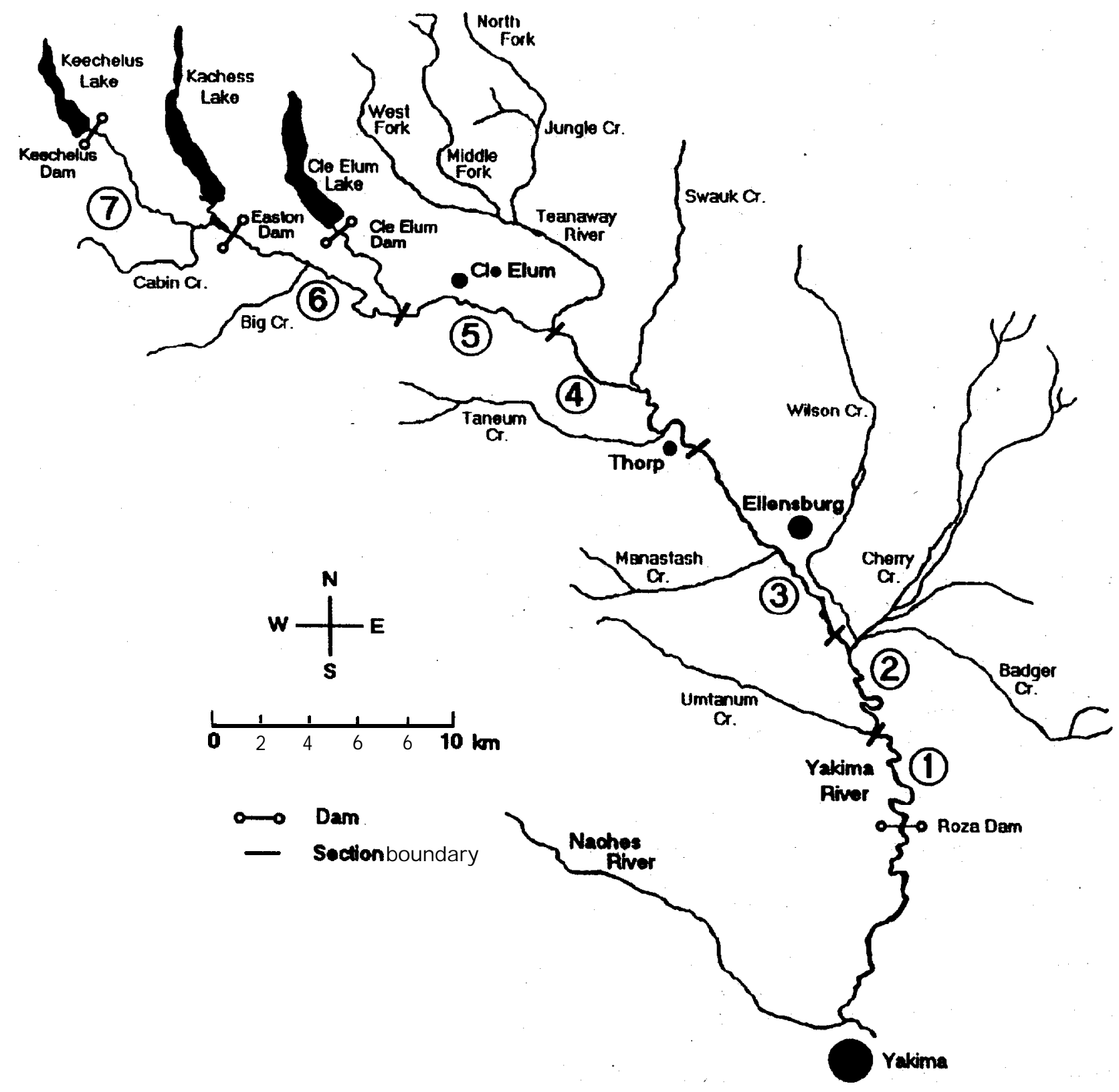

Figure 1. Map of the Yakima River drainage north of the city of Yakima. Study area includes the Yakima River and its tributaries between Roza Dam and Keechelus Dam. Mainstem Yakima River study sections $(1-7)$ are shown in circles. 
The Yakima River in this upper area is heavily braided and extensive log jams are common.

The intermediate zone of the study area is characterized by warmer and dryer conditions and reduced stream gradient. Important tributaries in this area are the Teanaway River, Swauk Creek and Taneum Creek. The Teanaway system is complex, with three major forks and a drainage area of.512 square kilometers (BPA 1990b). Its mainstem is $18.7 \mathrm{~km}$ long with the North Fork extending $30.4 \mathrm{~km}$, Middle Fork - $24 \mathrm{~km}$ and West Fork - $24 \mathrm{~km}$. Water temperatures warm slowly in the spring and spawning is delayed as snow-melt in the higher elevations keep stream temperatures cool.

Farther downstream the Yakima River enters the agricultural land of the Kittitas Valley west of the city of Ellensburg. A large diversion dam at rkm 233 (Ellensburg Dam) diverts water from the river for irrigation purposes. Fish passage facilities were completed in 1989 improving the effectiveness of the fish ladder and intake screens. Use of the Kittitas Valley is dominated by livestock grazing and hay production. Abundant smaller tributaries in the valley are used as sources of irrigation water with many having been artificially channelized in their lower reaches. The study tributaries in this area are Manastash, Wilson, Cherry and Badger creeks. During the irrigation season (mid-April through mid-October) the lower sections of these streams flow high and turbid (from irrigation water returns). 
South of Ellensburg the Yakima River enters the Yakima Canyon, located between the Kittitas and Yakima valleys. With a relatively small, steep drainage area and-reduced precipitation, only a few small streams enter the Yakima River in this area. The largest, Umtanum Creek, is the southernmost tributary in the study area. A large gabion at rkm 7.9 of Umtanum Creek blocks upstream migrations of all fish. A series of beaver dams beginning $1.6 \mathrm{~km}$ above the mouth of the creek may also form an upstream migration barrier.

Roza Dam forms the lower boundary of the study area. Before improvements in 1988, fish passage facilities at the dam were often ineffective and the dam may have acted as a barrier to the passage of anadromous fish (particularly steelhead). This was true especially during low flows ( $\mathrm{J}$. Hubble, YIN, pers. comm.). A total of seven study sections were selected in the mainstem Yakima River based on physical geographic features and broad habitat types (Figure 1). The upper reaches of the Yakima River (sections 7, 6, and 5) are within the forested zone of the lower Cascades that is characteristically montane in nature. Study section 4 is in the transition zone between the mountains and the Kittitas Valley. Conifers are gradually replaced by shrub-steppe vegetation and precipitation levels decline. Here, the river flows through a 'steep basaltic canyon that is the gateway to the Kittitas Valley. Section 3 is in the Kittitas Valley where the Yakima River is characterized by extensive channel braiding. A riparian corridor exists in this section 
which is composed of willow, alder and cottonwood. Sections 2 and 1 are in the Yakima Canyon and are divided by the confluence Umtanum Creek and the Yakima River. In this area the river broadens as it passes through basalt formations. This part of the river is heavily used by both recreational boaters and anglers and is well known for its high-quality rainbow trout fishery (L. Brown, WDW, pers. comm.).

The Yakima River above Roza Dam is presently managed as a catch-and-release trout fishery, which requires use of single barbless hooks and artificial lures only. The present regulations have been in effect since the spring of 1990. Previous regulations allowed one trout greater than 15 inches to be retained, and bait or barbed hooks were legal. The majority of anglers presently use fly-fishing gear with only a small portion using lures. Typically, fishing pressure is heavy on weekends and holidays, and light at other times. The Yakima River is popular for guided fishing trips.

Salmonid species observed in the study area included rainbow trout, cutthroat trout (0. clarki), putative hybrid trout (cutthroat $x$ rainbow), spring chinook salmon, wild steelhead, brook trout (Salvelinus fontinalis), bull trout '(S. confluentus), lake trout (S. namaycush), and mountain whitefish (Prosopium williamsoni). Cyprinid fishes collected include northern s'qauwfish (Ptychocheilus oregonensis), redside shiner (Richardsonius balteatus), speckled dace (Rhynichthys osculus), longnose dace (R. cataractae), chiselmouth (Acrocheilus 
alutaceus), and common carp (Cyprinus carpio). Catostomids observed were bridgelip sucker (Catostomus columbianus) and largescale sucker (C. macrocheilus). Cottids sampled include torrent sculpin (Cottus rhotheus), mottled sculpin (C. bairdi), and piute sculpin (C. beldingi). Fishes from various other families were also observed including: western brook lamprey (Lamptera richardsoni), burbot (Lota lota), three-spine stickleback (Gasterosteus aculeatus), largemouth bass (Micropterus salmoides), pumpkinseed (Lepomis gibbosus), and yellow perch (Perca flavescens). .

\title{
BASELINE PHASE
}

\author{
SPAWNING BURVEYS
}

Methods

\section{Tributaries}

Exploratory spawning surveys in selected tributaries of the Yakima River began on February 11, 1991. Electrofishing provided the opportunity to sample individual fish in varied water conditions and to assess the relative sexual maturity of those fish (Hindman et al. 1991). However, hook and line sampling was occasionally used when electrofishing was not effective.

Primary objectives of the spawning surveys were to 1) document when and where rainbow trout spawn in the upper Yakima 
River basin, and 2) determine the potential for overlap with steelhead spawning location and timing. To accomplish these objectives spawning surveys were conducted on a monthly basis for each of the 13 tributaries. Beginning at Umtanum Creek (the study stream with.the lowest elevation) and progressing westward (higher in elevation), each tributary was sampled from February through June. In each stream an increase in sexual maturity should be observable over time, followed by a subsequent decline, indicating the length and peak of spawning activity during a single season. However, poor sampling conditions (e.g. high flows and/or 'low conductivities) did not facilitate continuous monitoring in all areas.

Spawning surveys were conducted by a three-person sampling team. Typically, one person used a Smith-Root Model 12 backpack electrofisher (battery-powered) and a netter captured stunned fish while working in an upstream direction. The third crew member carried the sampling equipment and a bucket to hold captured fish. Sampled fish were anesthetized with MS-222 (tricaine methanesulfonate), identified to species, and measured to the nearest millimeter (fork length = FL). All captured trout were weighed to the nearest gram and scales were collected from a sub-sample for scale pattern analysis and age determination. Each fish was examined for the presence of hook-scars (e.g. scars on soft-tissues around mouth, missing or damaged maxillary or mandible) and examined for sexual maturity (spawning condition). All trout greater than $175 \mathrm{~mm}$ were then tagged with serially 
numbered Hallprint T-bar anchor tags and placed in a perforated holding bucket in the stream for recovery from the anesthetic. Once the fish recovered from the anesthetic they were released into the stream near where they were collected. Juvenile rainbow trout (between 120 and $174 \mathrm{~mm}$ ) in the Teanaway River system were tagged with visible implant (VI) tags, inserted in the-left adipose eyelid. These individually-coded tags were used to obtain movement information. We also measured water temperature $\left({ }^{\circ} \mathrm{C}\right)$ and water conductivity (mmhos/cm) during spawning surveys. Sexual maturity was determined by gently squeezing the abdominal area of each fish and observing for the expulsion of milt or eggs. Fish were then recorded as green (typical adult size range with no excretion of milt or eggs), mature (excretion of milt or eggs), spent (adult size range with hollow cavity with worn fins), or immature (smaller than the typical adult trout size range in that area). The smallest mature rainbow trout observed in each tributary was used as the lower limit to identify "potential" adult rainbow trout for each tributary.' The percentage of fish that were sexually mature fish was then calculated by dividing "mature" fish by all "potential" adults in a given sample.

A second objective of the spawning surveys was to determine the location of rainbow trout spawning areas. To accomplish this each tributary was divided'into three sections representing low, middle, and high elevation areas. In tributaries where the anadromous zone (areas accessible to salmon and steelhead) was 
short (e.g. Cabin and Umtanum creeks) the stream was divided into two sections. In streams with long anadromous zones (e.g. Taneum Creek) four sections were established. On each spawning survey, samples were taken from each section, thereby representing portions of the entire length of stream.

To identify potentially distinct genetic stocks of rainbow trout, and to assess population structure within the study area, sexually mature rainbow trout were sacrificed for genetic stock identification (GSI). The Washington Department of Fisheries (WDF) was subcontracted to perform the analysis (electrophoresis). A total of 100 samples wastargeted as the minimum number needed to detect population differences. However, due to potential impact to the trout resource, methods to reduce sampling effects were used. Areas with similar features were combined to form multi-sample clusters. In general, samples from three streams were used to form a cluster. Target sample size for each tributary within a cluster was 33. Tissue samples (heart, liver, muscle, and eye) were taken from fish greater than $150 \mathrm{~mm}$ while fish less than $150 \mathrm{~mm}$ were frozen whole for later dissection in the laboratory. Samples (tissues and whole fish) were frozen on dry ice in the field immediately after data collection. Scale pattern and age analysis of Yakima River resident trout were also performed via subcontract to WDF. Scale samples from all fish collected for GSI were placed on gummed cards and samples from an additional 17 fish were collected per tributary (total $N=50$ ). Scales were removed from the left side 
of each sampled fish from an area two to three scale rows above the lateral line posterior of the dorsal fin. Not all age data was available at this writing. Consequently, much of the inference regarding age classes was based on length frequency distributions.

Fecundity was determined by removing eggs from mature female trout that were sacrificed for genetic analysis, preserving the eggs in $10 \%$ formalin, and later counting the eggs in the laboratory. Water displacement methods (Piper et al. 1983) were used to estimate the total number of eggs per fish. Several tributaries were too large to sample with backpack electrofishing equipment, and too small for drift boat electrofishing. Thus we surveyed these areas using snorkeling techniques similar to those described by Schill and Griffith (1984). Three crew members equipped with dry-suits, masks and snorkels positioned themselves across the width of the stream and drifted downstream (usually a 2-5 $\mathrm{km}$ section) recording all fish observed and classifying the trout into two size groups, <150 mm in length, and $\geq 150 \mathrm{~mm}$. The different size groups were selected to differentiate between adult (potential spawner) and sub-adult segments of the population based on information obtained during the previous year (Hindman et al. 1991). However, exact length, weight, spawning condition, and genetic samples were not obtainable using snorkeling methods. This technique did, however, allow for rapid assessment of the presence/absence of adult salmonids. Relative abundance of non-salmonid species was 
also recorded during snorkel surveys.

A trap was placed in Umtanum Creek from April 16 to April 19, 1991 to test the feasibility of trapping adult rainbow trout, and to supplement baseline biological data regarding resident trout spawning timing. The trap was constructed so that trout ascending the stream would follow block nets to a funnel of hardware cloth and into the lower half of the live box. Fish migrating downstream were diverted by screened panels into a 10.2 cm PVC pipe that led to another portion of the live box. The trap was checked twice daily and fishes captured were sampled as described above prior to being released in the appropriate direction.

\section{Mainstem Yakima River}

As described by Hindman et al. (1991), the mainstem Yakima River was divided into seven study sections based on general geographical features The sequence of section numbers presented in this report has been reversed from that presented by Hindman et al. (1991) to be consistent with the numbering scheme used on the tributary sections (lower numbers associated with lower elevations). The new sequence is as follows: section 1 (Lower Canyon) from Roza Dam to Umtanum Creek ; Section 2 (Upper Canyon) from Umtanum Creek to Ringer Road access; Section 3 (Ellensburg) from the Ringer Road access to Ellensburg Dam; Section 4 (Thorp) from Ellensburg Dam to the Teanaway River confluence; Section 5 (Cle Elum) from the Teanaway River confluence to the cle Elum 
River confluence; section 6 (Nelson Siding) from the Cle Elum River confluence to Easton Dam; section 7 (Crystal Springs) from Easton Dam to Keechelus Dam.

Sections 1 to 5 were accessible with a boat and thus were sampled by driftboat electrofishing. Snorkeling techniques (Schill and Griffith 1984) were used in areas of the Yakima River that were too large for backpack electrofishing but that were not accessible with a boat. In a few instances, hook and line sampling was used to capture fish for the spawning survey and to obtain samples for genetic analysis and tagging.

Surveys conducted by Hindman et al. (1991) in 1990 used a jet boat electrofisher. In 1991, the jet boat was supplanted with a driftboat electrofisher. A $7.1 \mathrm{~m}$ fiberglass driftboat was rigged with a $3500 \mathrm{w}$ gasoline-powered Honda generator and a Coffelt Mark XXII rectifier. The anode was a $102 \mathrm{~cm}$ diameter Wisconsin ring mounted on a stationary boom. The cathode was a $25 \mathrm{~cm} \times 4.5 \mathrm{~m}$ aluminum plate mounted in a recessed keel on the bottom of the boat.

Typically, the boat operator would maneuver the boat toward a river bank while the netter was stationed at the bow of the boat. All trout were netted and placed in an onboard live box and data collectionwas performed at regular intervals as discussed for tributaries. Surveys were performed on a schedule similar to that described for the tributaries. Each river section was sampled one day per month by drifting a 4-6 km long section. Specific areas electrofished within a section were 
alternated so that effort would be spread out over an entire section as the season progressed and to minimize impacts to the resource associated with sampling. Trout were measured to the nearest millimeter (FL), weighed to the nearest gram, and examined for hook scars and sexual maturity. Methods to determine the percentage of sexually mature were the same as discussed for tributaries. To determine the approximate timing of spawning activity in the mainstem, the percentage of sexually mature fish was graphed by section over time.

Tissue samples were collected from a sub-sample of mature fish from each section $(N=20)$ for genetic analysis. Scale samples were also collected from these fish, and scales from an additional 20 fish per section were collected from each section to improve sample sizes for age determination as well as scale patternanalyses.

Results and Discussion

Tributaries

UMTANOM CREEK

Spawning surveys in Umtanum Creek were conducted on February 11, March 4, March 18, and April 3. The percentage of sexually mature fish observed during spawning surveys in Umtanum Creek peaked in the lower section on March 18 (57\%) and declined by early April (26\%). In both sections combined, spawning peaked during March surveys (Figure 2). These results are consistent 
with those of 1990 where $88 \%$ of the trout sampled were sexually mature on March 21 and 22 (Hindman at al. 1991). The number of new redds observed in Umtanum Creek peaked on April 8 and subsequently declined until no new redds were observed after April 18 (Harper and Divens, CWU, unpub. data). The percentage of sexually mature fish was similar in both sections of Umtanum Creek indicating some spawning does occur throughout the lower $7.9 \mathrm{~km}$ of this stream. However, use by mainstem fish above rkm 1.5 is questionable due to numerous beaver dams which may act as barriers to upstream migration.

Numerous rainbow trout spawning pairs were observed in this small stream on April 3, prompting use, of a less intrusive method of sampling to determine spawning timing. Accordingly, a trap was constructed to capture upstream and downstream migrants from April 16 to April 19. No fish moving upstream were captured, indicating .the upstream spawning movement had previously been completed. In addition no trout were observed in the pool below the trap, suggesting upstream fish migrations were not being inhibited by the trap. Thirteen emigrant rainbow trout leaving the stream (all recorded as spent) were captured during four successive days of trapping. Migrant trapping will be refined and used for the spawning survey in Umtanum Creek in 1992. 


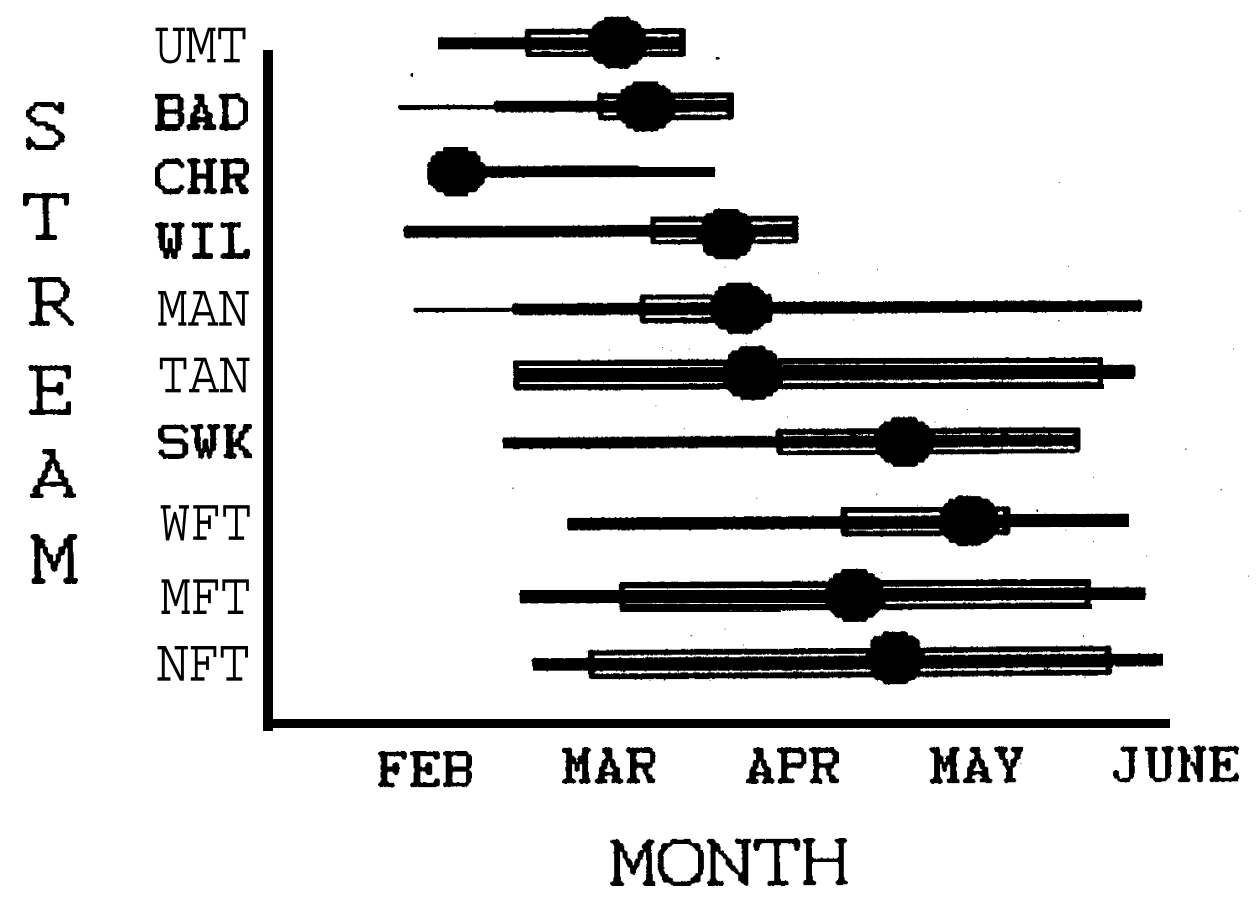

Figure 2. Spawning timing of resident rainbow trout in tributaries to the upper Yakima River during spawning surveys in 1991. Dots show estimated peak of spawning activity, boxes denote periods when $10 \%$ or more of the fish sampled were sexually mature, thick lines show periods when one to nine percent of the fish were sexually mature, and thin lines cover periods when no fish in spawning condition were sampled. UNT = Umtanum $\mathrm{Cr}$. BAD = Badger Cr., CHR = Cherry Cr., WIL = Wilson Cr., MAN = Manastash Cr., TAN $=$ Taneum $\mathrm{Cr} .$, SWK $=$ Swauk Cr., WFT $=\mathrm{W}$. Fork Teanaway, MFT $=$ Middle Fork Teanaway, and NFT $=\mathbf{N}$. Fork Teanaway.

A total of 294 trout were sampled in Umtanum Creek spawning surveys in 1991. Tags were placed in 25 trout $>175 \mathrm{~mm}$ and five fish were captured bearing tags from the previous year. The condition factor for rainbow trout sampled in the lower section of Umtanum Creek (0.86) was slightly lower than that of the upper section (1.00) (Table 1). Fish from the lower section also exhibited a higher percentage of hook scars (6\%) than those sampled in the upper section (1\%). Similarly, more hook-scarred fish were also observed in the lower section in 1990, although 
the percentage (34\%) was substantially higher than in 1991.

Rainbow trout collected in the lower section (below the beaver dams) were slightly larger (mean = $141 \mathrm{~mm}$ ) than fish collected in the upper section (above the dams) (mean $=120 \mathrm{~mm}$ ). The mean length for fish from the lower section was lower in 1991 than it was the previous year (mean $=220 \mathrm{~mm}$ ) which may be a result of capturing more juvenile fish in 1991 when a broader period of time was sampled. The length frequency distribution for Umtanum Creek shows the presence of older age classes in the lower section only (Figure 3 ).

These results suggest that the beaver dams $1.6 \mathrm{~km}$ up Umtanum Creek acted as partial or complete barriers to upstream movement by trout from the Yakima River. Preliminary genetic results detected no difference between upper resident fish and lower riverine groups within Umtanum Creek during the spawning season.

Eggs from four female rainbow trout from Umtanum Creek were enumerated. Mean fecundity of these fish was 347 eggs/female (Table 2). Although only one of the four fish (311 mm FL) was captured in the lower section it carried 686 eggs.' The habitat of Umtanum Creek has been relatively undisturbed by human activities, with good spawning and rearing habitat present. Low summer flows $\left(<0.03 \mathrm{~m}^{3} / \mathrm{s}\right)$ have been reported in the lower $1.6 \mathrm{~km}$, with some stretches having intermittent flow (BPA 1990b). Low summer flows may be a factor stimulating trout to 
Table 1. Summary of rainbow trout captured by stream and section during 1991 spawning surveys. Sample size (N), minimum (Min), maximum (Max), and mean fork length (Mean), standard deviation (SD), average condition factor (CF), percentage of sexually mature fish, and percentage of fish that were hookscarred. Stream sections are numbered in ascending order in an upstream direction.

\begin{tabular}{|c|c|c|c|c|c|c|c|c|}
\hline \multirow{2}{*}{$\begin{array}{l}\text { Stream/ } \\
\text { Section }\end{array}$} & \multirow[b]{2}{*}{$\mathbf{N}$} & \multicolumn{3}{|c|}{ Fork Lenath (mm) } & \multirow[b]{2}{*}{ SD } & \multirow{2}{*}{$\begin{array}{l}\text { Avg. } \\
\text { CF }\end{array}$} & \multicolumn{2}{|c|}{ Percentaae } \\
\hline & & $\operatorname{Min}$ & $\operatorname{Max}$ & Mean & & & Mature & Hook-scar \\
\hline UMT 1 & 155 & 49 & 385 & 141 & 86 & 0.86 & 27 & 6 \\
\hline UMT 2 & 139 & 62 & 219 & 120 & 27 & 1.00 & 32 & 1 \\
\hline POOLED & 294 & & & 131 & & 0.93 & 29 & 4 \\
\hline CHR 1 & 102 & 94 & 355 & 180 & 72 & 0.96 & 9 & 4 \\
\hline CHR 2 & 19 & 97 & 332 & 166 & 72 & 1.04 & 0 & 5 \\
\hline CHR 3 & 19 & 92 & 352 & 183 & 69 & 0.93 & 0 & 5 \\
\hline POOLED & 140 & & & 178 & & 0.97 & 7 & 4 \\
\hline BAD 1 & 56 & 79 & 357 & 149 & 50 & 1.05 & 4 & 0 \\
\hline BAD 2 & 45 & 121 & 465 & 170 & 66 & 1.07 & 24 & 2 \\
\hline BAD 3 & 33 & 90 & 270 & 151 & 38 & 0.95 & 13 & 0 \\
\hline POOLED & 134 & & & 157 & & 1.03 & 13 & 1 \\
\hline WIL 1 & 18 & 106 & 440 & 316 & 85 & 0.85 & 31 & 22 \\
\hline WIL 2 & 58 & 147 & 465 & 340 & 71 & 0.86 & 25 & 5 \\
\hline WIL 3 & 24 & 117 & 342 & 231 & 59 & 0.85 & 28 & 8 \\
\hline POOLED & 100 & & & 309 & & 0.86 & 27 & 9 \\
\hline MAN 1 & 61 & 76 & 280 & 165 & 56 & 0.95 & 35 & 0 \\
\hline MAN 2 & 17 & 68 & 222 & 143 & 43 & 1.09 & 33 & 0 \\
\hline MAN 3 & 36 & 67 & 214 & 131 & 38 & 0.99 & 54 & 0 \\
\hline POOLED & 114 & & & 151 & & 0.98 & 41 & 0 \\
\hline TAN 1 & 35 & 71 & 298 & 138 & 59 & 0.94 & 19. & 0 \\
\hline TAN 2 & 42 & 85 & 213 & 152 & 33 & 1.02 & 27 & 9 \\
\hline
\end{tabular}


Table 1 . continued

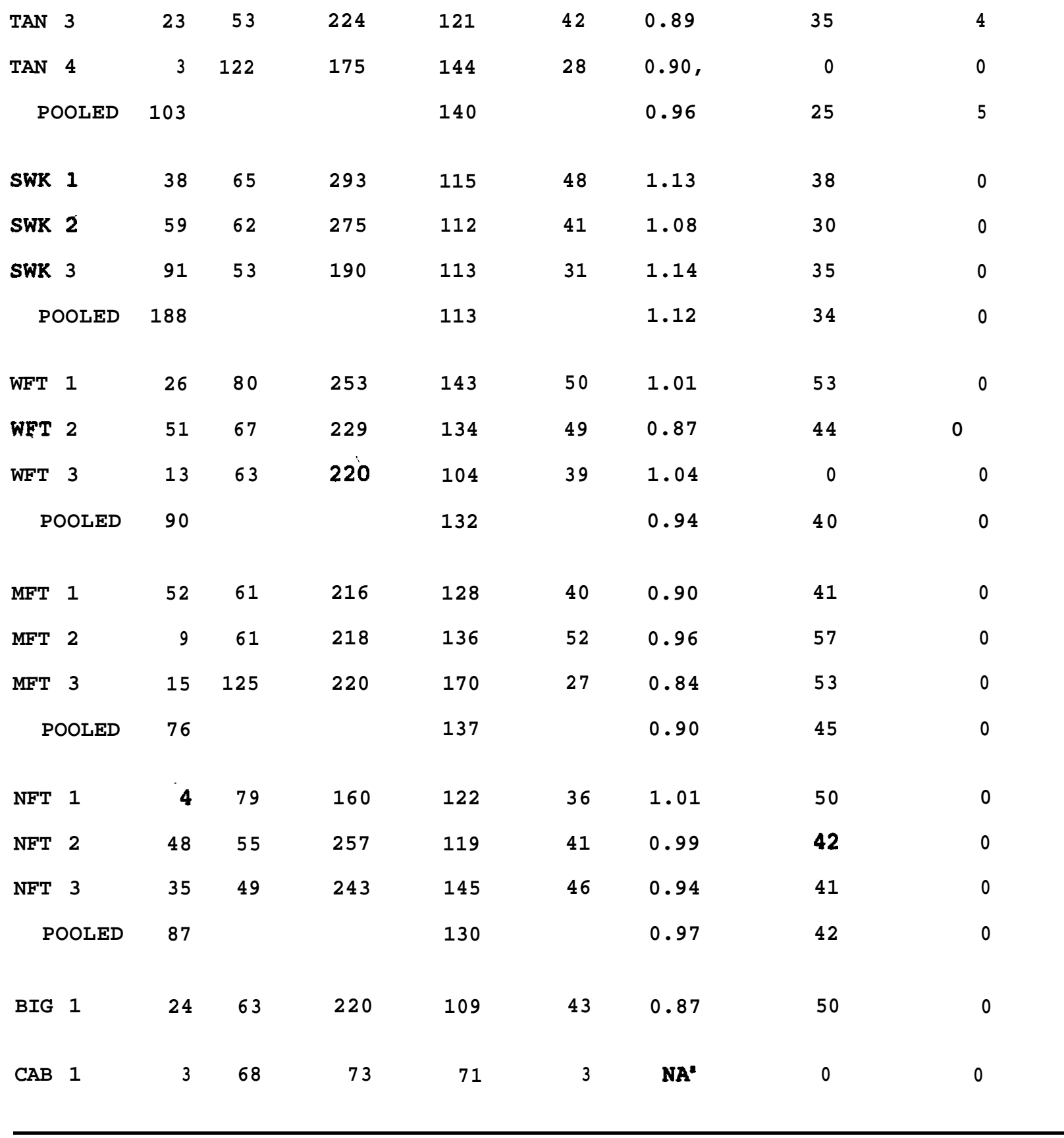

- weights not available. 


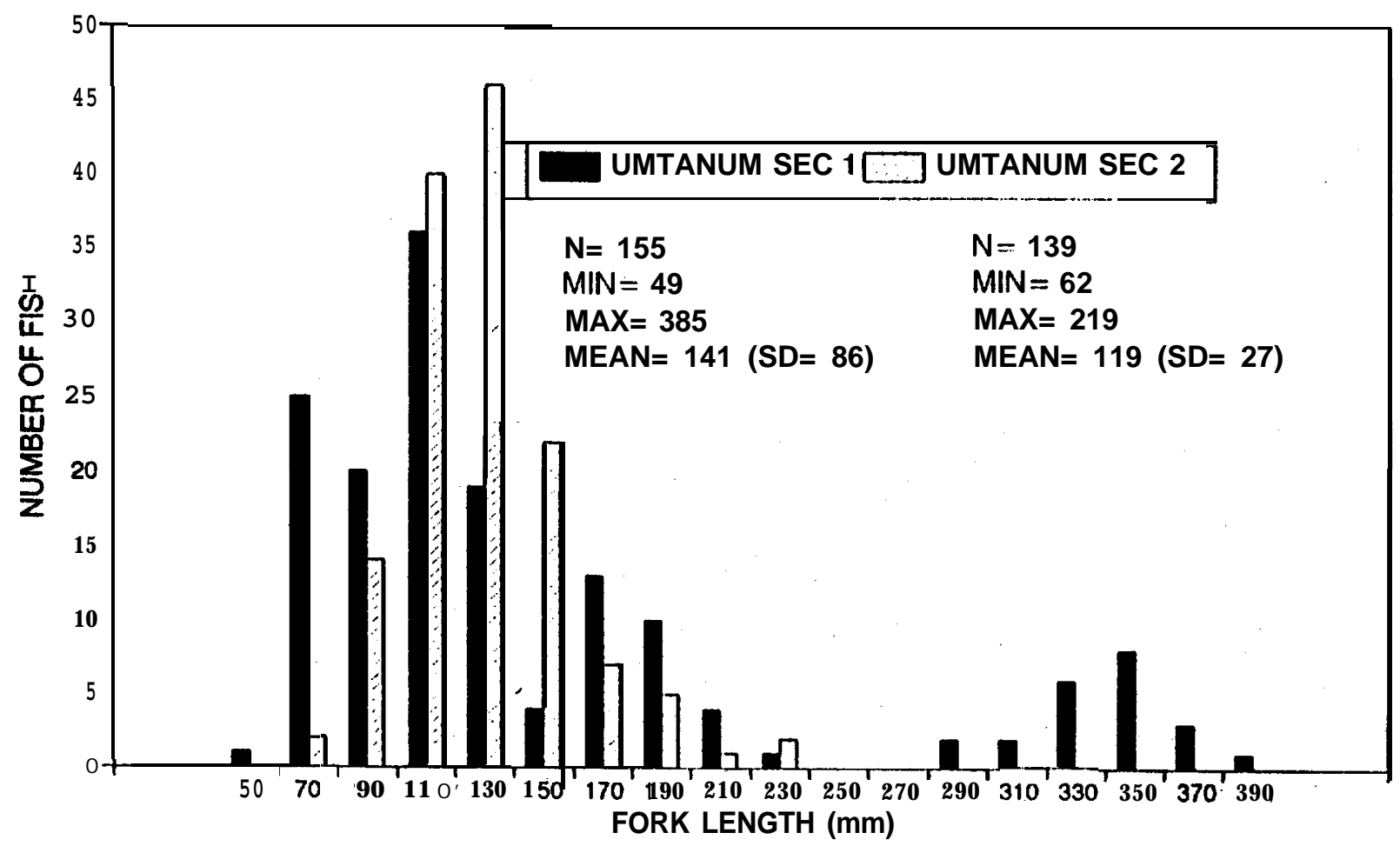

Figure 3. Length frequency histogram of rainbow trout captured in two sections of Umtanum Creek spawning surveys in the.spring, 1991 .

Table 2. Number of fish sampled (N), mean length, mean weight, fecundity (eggs/fish), and eggs/mm of fish length for egg skeins collected from mature female rainbow trout during spawning surveys in 1991.

\begin{tabular}{|c|c|c|c|c|c|c|c|c|c|}
\hline \multirow[b]{2}{*}{ St ream } & \multirow[b]{2}{*}{$\mathbf{N}$} & \multicolumn{2}{|c|}{ Length } & \multicolumn{2}{|c|}{ Weiaht } & \multicolumn{2}{|c|}{ eqgs/fish } & \multicolumn{2}{|c|}{ eqas $/ \mathrm{mm}$} \\
\hline & & Mean & Range & Mean & Range & Mean & Range & Mean & Range \\
\hline Umtanum & 4 & 188 & 135- 311 & 119 & $32-349$ & 347 & $150-686$ & 1.7 & $1.1-2.2$ \\
\hline Badger & 2 & 293 & $211-374$ & 329 & $114-544$ & 1076 & $252-1900$ & 3.1 & $1.2-5.1$ \\
\hline wilson & 7 & 386 & $223-465$ & 800 & $118-1270$ & 2151 & 270-3102 & 5. 2 & $1.2-6.8$ \\
\hline Manastash & 2 & 198 & $165-231$ & 140 & $53-227$ & 540 & $240-840$ & 2.5 & $1.5-3.6$ \\
\hline Taneum & 5 & 182 & $147-213$ & 80 & $30-129$ & 342 & $161-500$ & 1.8 & $1.1-2.4$ \\
\hline
\end{tabular}


move downstream to suitable habitat in the river. The clean substrate and undisturbed nature of this drainage may mean'that it is also desirable as a spawning and/or rearing stream for steelhead. One spent female steelhead was captured in Umtanum Creek in 1990 (Hindman et al. 1991).

Umtanum Creek provided the best opportunity for observing spawning behavior and quantifying redd descriptions. Harper and Divens (CW, unpub. data) recorded detailed measurements from 29 active redds on Umtanum Creek from March 28 to April 15, 1991. Other species present in Umtanum Creek included spring chinook salmon, speckled dace, sculpins, and bridgelip suckers.

\section{BADGER CREEK}

Badger Creek was added as a study stream in 1991 although it was not sampled during 1990 surveys. A total of 134 rainbow trout were sampled in Badger Creek surveys beginning on February 13, and ending on April 4. In addition, 173 trout were observed. with phenotypic characteristics which appeared to be intermediate between rainbow and cutthroat trout, possibly reflecting rainbowcutthroat trout hybrids. The percentage of sexually mature rainbow trout increased from $0 \%$ in February to $21 \%$ in early April, at which time six spent trout (four females) were recorded (Figure 2). Irrigation return water dramatically increased the' flow in this stream by early May, decreasing subsequent electrofishing success after that time. Although no rainbow trout captured on surveys in February were mature, one large 
cutthroat female was sexually mature, indicating that some salmonid spawning does occur early in Badger Creek. Water temperatures recorded during surveys of Badger Creek ranged from $9{ }^{\circ} \mathrm{C}$ on February 13 to $11^{\circ} \mathrm{C}$ on April 4. Piper et al. (1983) reports optimum spawning temperatures for rainbow trout to be 10 to $13^{\circ} \mathrm{C}$. Due to the presence of the spent females in early April and the warm water temperatures encountered, spawning in this tributary probably peaked between late March and early April. Similar results were found in nearby Wilson Creek (Figure 2).

The length frequency distribution for Badger Creek rainbow trout (Figure 4A) suggests that the population had a relatively young age distribution. For example, $82 \%$ of the rainbow trout sampled were less than $175 \mathrm{~mm}$ in length. Few fish from older year classes were observed. However, sub-adult populations were probably under-represented because many small trout were not netted in an attempt to capture the larger fish likely to be of spawning age. A large trout (465 mm) was captured in Badger Creek that was the same length as a fish from Wilson Creek. These were the two largest trout captured during spawning surveys in 1991. The overall mean length of Badger Creek rainbow trout was $157 \mathrm{~mm}$ (Table 1).

Observations of stomach contents of these Badger Creek fish showed large numbers of freshwater shrimp (Amphipoda) present. 

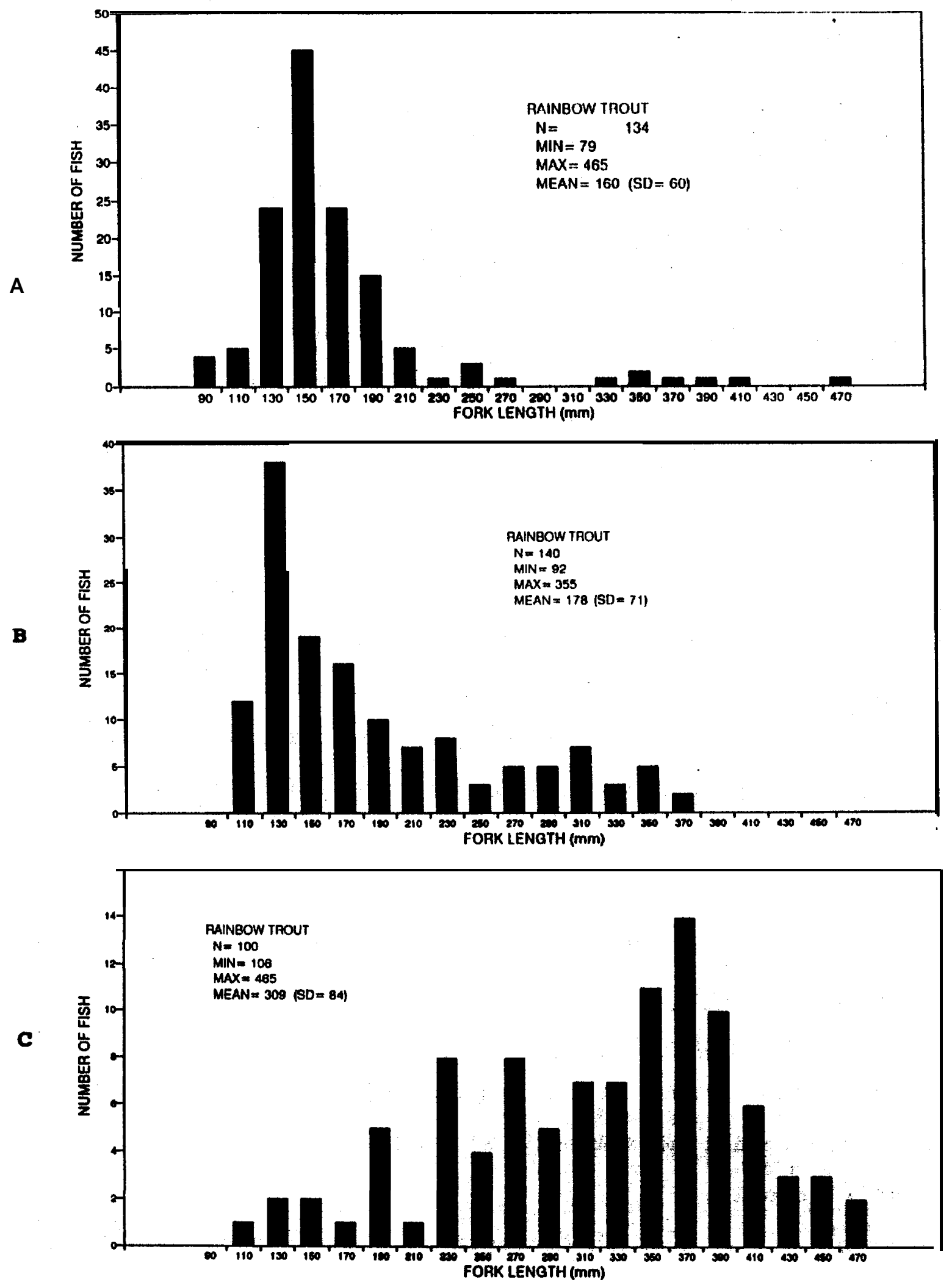

Figure 4. Length frequency histograms of rainbow trout captured in Badger (A), Cherry (B), and Wilson. (C) creeks during spawning surveys in 1991. 
Mean number of eggs/fish from Badger Creek was 1,076 (Table 2). The number of eggs per millimeter of fish length was second only to Wilson Creek.

Tags were placed in 40 rainbow trout $>175 \mathrm{~mm} \mathrm{FL}$. No recaptures were recorded. Condition factors were relatively high in Badger Creek ranging from 0.95 in the lower section to 1.07 in the middle section (Table 1). The majority of rainbow trout spawning appears to take place upstream of Emerson Road (3.5 km from confluence with Cherry Creek).

In addition to wild rainbow and cutthroat trout, we observed spring chinook salmon, speckled and longnose dace, . hatchery rainbow trout, redside shiners, and bridgelip suckers were observed in Badger Creek.

\section{CHERRY CREER}

Spawning surveys were conducted in Cherry Creek on February 12, March 5, March 20, and April 2. Spawning surveys' were discontinued in this creek after April because high flows due to irrigation runoff prevented effective electrofishing. Of the total number of rainbow trout sampled $(\mathrm{N}=156), 45$ rainbow trout were considered potential spawners (>185 mm) while only three were recorded as sexually mature (two in February). Although the sample size was small, the presence of mature trout in February indicates the start of spawning occurred early in this stream. The mean size of rainbow trout captured in Cherry Creek in 1991 (178 $\mathrm{mm})$ was smaller than during the previous spring $(213 \mathrm{~mm})$ 

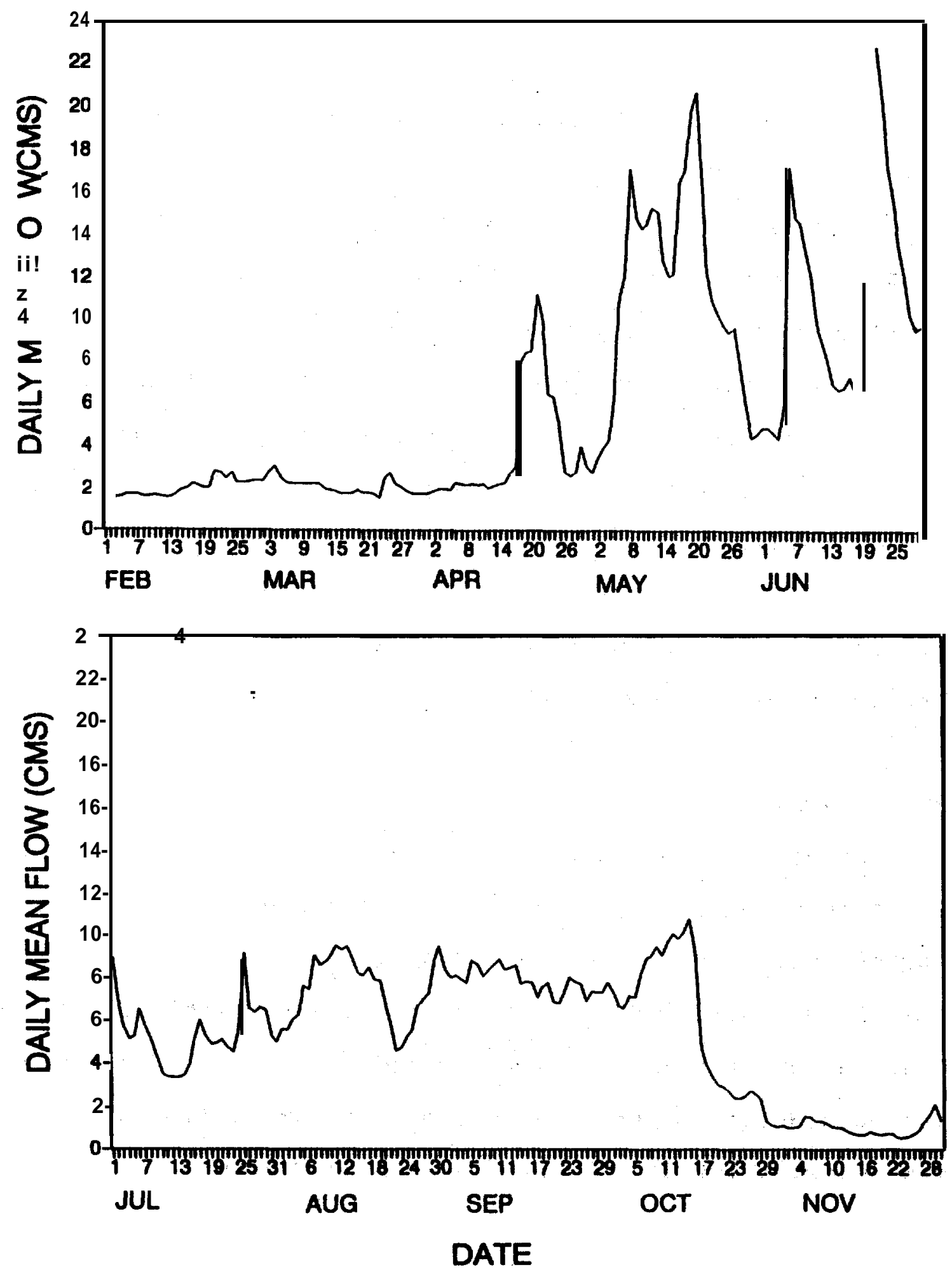

Figure 5. Daily discharge in cubic meters per second (CMS) for Cherry Creek from February 1 through November 30, 1991 (USBR, unpublished data). 
(Hindman et al. 1991) (Figure 4B). Results from surveys in 1990 indicated $15 \%$ of the fish were sexually mature in early March (Hindman et al. 1991). Water temperatures generally warm early in this stream as snow melt on the south slope of the lower Colockum Ridge (which feeds Cherry Creek) occurs early in the spring. Temperatures recorded on surveys ranged from $7{ }^{\circ} \mathrm{C}$ on February 12 to $11^{\circ} \mathrm{C}$ on March 20, indicating spawning season could coincide with this early increase in stream temperatures.

A total of 50 rainbow trout $(>175 \mathrm{~mm}$ ) were tagged in Cherry Creek during 1991 surveys. A total of four tagged fish were subsequently recaptured; All four of these fish were-observed near the point of original capture. The lower section of Cherry Creek contained 9\% sexually mature trout, whereas no sexually mature trout were found in the upper two sections. No fish from Cherry Creek were sampled for fecundity.

other species observed in Cherry Creek were spring chinook salmon, mountain whitefish, longnose dace, largescale and bridgelip suckers, three-spine sticklebacks, and redside shiners.

\section{WILSON CREEK}

Wilson Creek was surveyed on February 15, March 5, March 20, April 4, April 15, and April 30. This tributary was sampled relatively frequently in order to increase sample size throughout the spawning period. A total of 100 rainbow trout were sampled. Mean size of trout from this creek (309 mm) was the largest of all tributaries sampled in 1991 (Table 1, Figure 4C), and was 
larger than that of the previous year $(260 \mathrm{~mm}$ ) (Hindman et al. 1991). Wilson Creek is oriented to the south and has a relatively low elevation, causing water temperatures to warm relatively early in the year. Stream temperatures were $8{ }^{\circ} \mathrm{C}$ when the first survey was conducted on February 15 , and reached $11{ }^{\circ} \mathrm{C}$ on March 20.

Percentage of sexually mature rainbow trout increased steadily over time with the highest frequency occurring in April (41\%) (Figure 2). Surveys conducted in March, 1990, found a low percentage of sexually mature fish (11\%; Hindman et al. 1991).

The presence of spent fish indicated that spawning was nearly complete by the end of April. A total of three and four spent rainbow trout were observed on April 4, and April 30, respectively. High irrigation flows caused termination of spawning surveys in Wilson Creek after the April 30 survey. The percentage of sexually mature rainbow trout was similar in all three sections of Wilson Creek, indicating that some spawning occurred throughout the area surveyed (lower Wilson Creek) (Table 1). A total of 64 rainbow trout $>175 \mathrm{~mm}$ were tagged during the spawning surveys in this creek. Fourteen trout that had been tagged during previous surveys were also captured. The length frequency distribution reflects a wide range of rainbow trout age classes in Wilson Creek at the time of our surveys (Figure 4C). Fish growth (size at age based on length frequency distributions) in the sampled sections of this creek appeared to be higher than average for this species in other 
areas, such as Montana waters (Brown 1971).

Wilson Creek trout had a higher mean 'number of eggs per fish $(2,151)$ than any other stream sampled (Table 2). Mean number of eggs per millimeter of fish length was also much higher for Wilson Creek rainbow trout than for fish in any of the other tributaries sampled.

Movement information from tag return data for Wilson Creek indicated that adult rainbow trout display little movement into or out of the stream (see Movement and Growth, this report).

Species diversity was relatively high in Wilson Creek with rainbow and brook trout, spring chinook salmon, mountain whitefish, hatchery rainbow, wild steelhead, largescale and bridgelip suckers, longnose dace, and redside shiners being observed.

\section{MANASTASH CREEK}

Manastash Creek was surveyed on February 14, March 6, March 25, April 5, June 4 and June 6. On February 14, 18 rainbow trout were captured in Manastash Creek and none appeared mature enough to spawn. Water temperatures ranged'from $3^{\circ} \mathrm{C}$ on February' 14 to $9{ }^{\circ} \mathrm{C}$ on June 6. Surveys indicated spawning began in March and peaked in April (Figure 2).

The three sections of Manastash Creek sampled had similar percentages of rainbow trout spawners, with a slightly higher 
percentage occurring in the uppermost section (Table 1). The length frequency distribution of rainbow trout sampled suggests. that there were three age classes present in Manastash Creek during the spawning survey period (Figure 6A). The smallest sexually mature rainbow trout captured in Manastash Creek were a $114 \mathrm{~mm}$ male and a $165 \mathrm{~mm}$ female.

A total of 114 rainbow trout were sampled during spawning surveys in Manastash Creek. The mean length of $151 \mathrm{~mm}$ for rainbow trout sampled in Manastash Creek in 1991 was slightly smaller than the mean length reported for the spring of 1990 (188 mm) by Hindman et al. (1991).

Varipus species were observed in Manastash Creek with rainbow, brook, and cutthroat trout, spring chinook salmon, mountain whitefish, sculpins, and dace present. A total of 20 tags were placed in trout $>175 \mathrm{~mm}$.

\section{TANEUX CREEK}

In 1991, Taneum Creek spawning surveys occurred on March 6, May 22, and June 11. Spring runoff made this stream extremely difficult to sample in April and May; wherein no fish were collected. The percentage of sexually mature fish was highest in March (31\%), although similar results were encountered on the June survey $(27 \%)$. These data suggest that spawning may occur over an extended period and may peak during high flows in April and May (Figure 2). During spawning surveys in 1990, three 

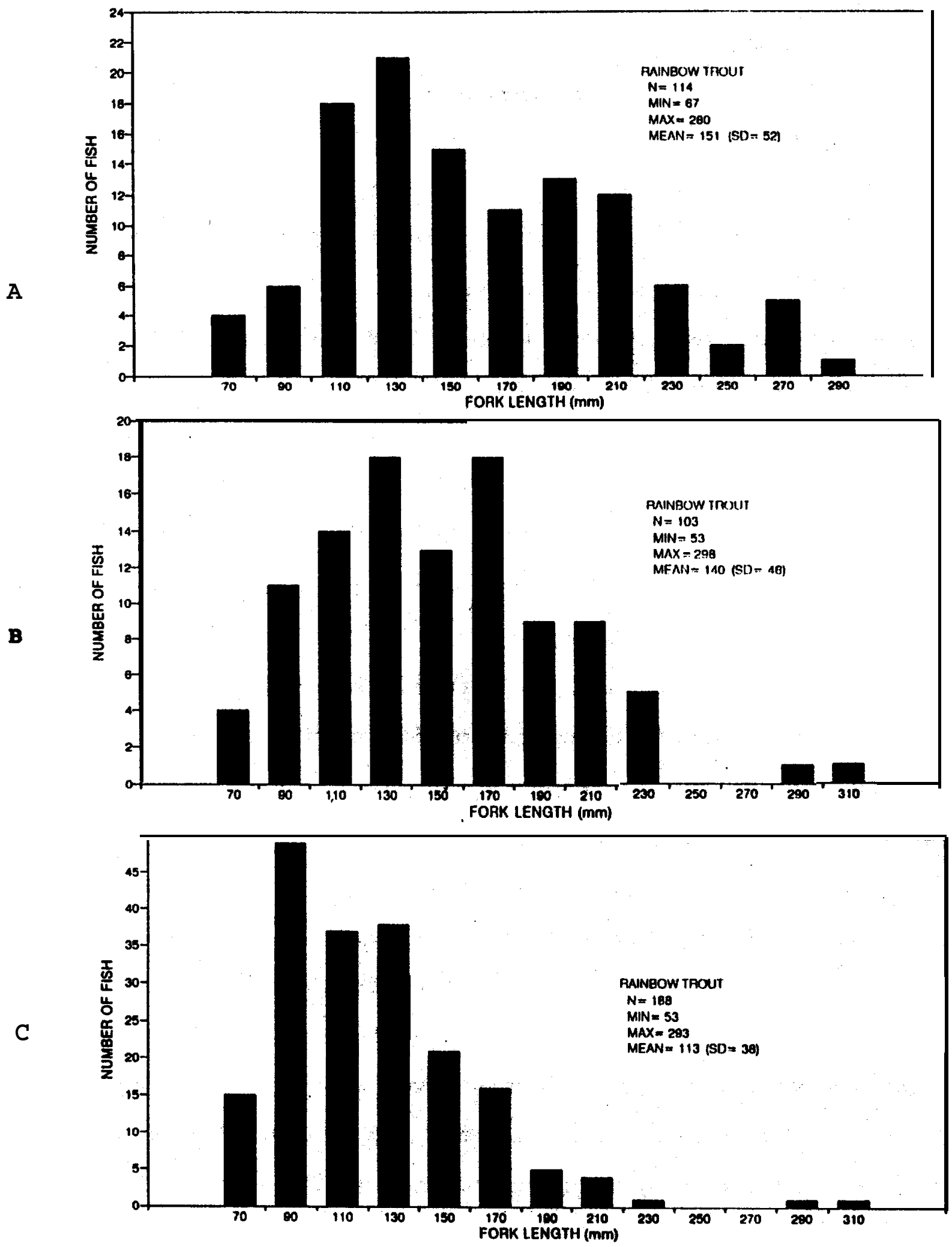

Figure 6. Length frequency histogram of rainbow trout captured in Manastash (A), Taneum (B), and Swauk (C) creeks during spawning surveys in 1991 . 
sexually mature females were observed on May 16, indicating that spawning may have occurred in, this stream during the high water period when electrofishing was of limited effectiveness (Hindman et al. 1991). The percentage of spent female trout increased during later samples in 1991, with 18 and 22\% being recorded for May and June samples, respectively.

Temperatures taken during spawning surveys ranged from $2{ }^{\circ} \mathrm{C}$ on March 6 to $10^{\circ} \mathrm{C}$ on June 11. Hindman et al. (1991) observed a large spawning run of bridgelip suckers into Umtanum Creek (from the mainstem Yakima River) shortly after the completion of rainbow trout spawning there.

The percentage of sexually mature fish in Taneum Creek appeared to increase in an upstream direction (19\%, 27\%, and 35\%. in sections 1,2 , and 3 , respectively; Table 1). No adult mature rainbow trout were sampled in the uppermost section surveyed, although the number of fish sampled was low $(\mathrm{N}=3)$.

A total of 103 rainbow trout were captured in Taneum Creek with a mean size of $140 \mathrm{~mm}$. The length frequency distribution for Taneum Creek shows a large portion of the population between 110 and $170 \mathrm{~mm}$ FL and very few fish over $250 \mathrm{~mm}$ FL (Figure 6B). Tags were placed in 11 trout $>175 \mathrm{~mm}$, and no tagged fish were recaptured there during spawning surveys in 1991.

The fecundity of five sexually mature females from Taneum Creek was examined. Mean length and number of eggs per female 
was relatively low and very similar to data from Umtanum Creek (Table 2).

Other species present included brook and cutthroat trout, putative rainbow/cutthroat trout hybrids, spring chinook salmon, suckers, mountain whitefish, sculpins, dace, and redside shiners. Hook-scarred fish were captured in the middle and upper sections indicating some fishing pressure occurred in those areas.

Low summer flows $\left(0.03-0.06 \mathrm{~m}^{3} / \mathrm{s}\right)$ and high temperatures $\left(20^{\circ} \mathrm{C}\right)$ have been reported in the lower $5.3 \mathrm{~km}$ of Taneum Creek (BPA 1990b). The seasonal de-watering of the stream below the Brunton Diversion may cause juvenile salmonids rearing in'that area to move downstream to the Yakima River. Until recently, no upstream passage was possible at either the Brunton Diversion or the Taneum Ditch Diversion. Recent improvements (fish ladders and screens) have been installed at both diversions which should make a substantial amount of good spawning and rearing habitat available to anadromous salmonids.

\section{SWAUK CREEK}

Spawning surveys were conducted in Swauk Creek on March 11, April 1, May 23, and June 11. The percentage of sexually mature fish peaked in May (54\%) and declined sharply in June (14\%) (Figure 2). Findings for June 1991 were similar to those of June, 1990, when $22 \%$ of the fish sampled were observed to be 
sexually mature (Hindman et al. 1991).

Water temperatures measured on March 11 were $3{ }^{\circ} \mathrm{C}, 11^{\circ} \mathrm{C}$ on May 23 and $14^{\circ} \mathrm{C}$ on June 11, 1991. On the June 11, 1991 survey, $38 \%\left(\mathrm{~N}^{\prime}=8\right)$ of the rainbow trout observed were spent, suggesting that spawning was nearing completion.

The length frequency distribution for Swauk Creek suggests that predominantly younger age classes of trout were present (Figure 6C). Mean'trout size among individual study sections of Swauk Creek were similar (Table 1).

Spawning appeared to be distributed relatively evenly throughout Swauk Creek with the percentage of sexually mature fish being $38 \%, 30 \%$, and $35 \%$ in sections 1,2 , and 3 , respectively (Table 1). Of all the streams sampled, Swauk Creek fish had the highest mean condition factors (Table 1).

Species other than rainbow trout that were observed in Swauk Creek included cutthroat trout, apparent cutthroat $\mathbf{x}$ rainbow hybrids, dace, sculpin, and suckers.

The lower 4 to $8, \mathrm{~km}$ of Swauk Creek may become dewatered in years of low precipitation (BPA 1990b).

\section{LOTER TEAMATAY RIVER}

Although considerable natural production potential exists throughout the Teanaway River basin, developing feasible spawning survey methods in the river below the confluence of the North and 
Middle Forks has been problematic. Spawning surveys in the lower Teanaway have been extremely difficult to conduct due to high flows and low water conductivities. The water volume has generally been too great for the backpack electrofisher to be effective and drift boat operation has been hampered by the presence of rapids and channel obstructions. We attempted to sample this part of the river on March 19, 1991. We rafted the mainstem Teanaway River and used the backpack electrofisher in backwater and braided areas of the river. Only two sub-adult rainbow trout and one spring chinook juvenile were captured. A snorkel survey was also attempted on March 12 but no fish were observed.

High quality spawning and rearing habitat is present in all three forks of the Teanaway system, which historically produced steelhead, chinook, and coho salmon (0. kisutch) (BPA 1990c). Present constraints to salmonid production include naturally low flows in the summer and fall which are exacerbated by irrigation diversions in the main Teanaway below the confluence of the North and Middle forks. In the summer of 1990, flows in the lowermost Teanaway River ranged from 0.2 to $2.1 \mathrm{~m}^{3} / \mathrm{s}$.

Low summer flows in the lower mainstem of the- Teanaway River may negatively impact juvenile salmonid production by increasing water temperature and increasing exposure to predators. High water temperatures and low flows may also interfere with or 
inappropriately induce movements of anadromous fish into and out of the system. For example, adult spring chinook migrate into spawning streams from April through July and peak spawning occurs in September (BPA 1990C). This period coincides with the period of lowest flows in the Teanaway River and may impede the movements of spring chinook -into the upper reaches of the basin.

\section{WEST FORK TEAMATAY}

Spawning surveys on the West Fork of the Teanaway River were conducted on March 19, March 21, May 29, May 30, June 13, June 20 and June 21. A portion of the adult trout sampled in June were classified as spent ( 8 of 23). Bridgelip suckers were observed in full spawning coloration during the June survey. If, as Hindman et al. (1991) suggested, bridgelip sucker spawning can be used as an indicator of the completion of trout spawning in a given area, then we could'surmise that the rainbow trout in the West Fork of the Teanaway River were done spawning by late June, 1991. The percentage of sexually mature trout in the West Fork Teanaway peaked in May (57\%) (Figure 2). There were no sexually mature rainbow trout sampled in the uppermost section of the West Fork although a spent rainbow male and a spent hybrid female were recorded, indicating that spawning does occur in this section. Spawning was evenly distributed between the lower two sections as 53\% and $44 \%$ of the trout sampled were sexually mature (Table 1). 
The mean length of rainbow trout captured in the West Fork (132 $\mathrm{mm}$ ) was similar to that of the adjacent Middle $(137 \mathrm{~mm})$ and North Forks (130 mm) (Table 1, Figure 7). The condition factor however was 0.77 , the lowest of any tributary studied.

Adult steelhead have been observed in the West Fork during rainbow trout spawning season by the authors of this report as well as YIN personnel ( $\mathrm{J}$. Hubble, pers. comm.). It is possible that steelhead spawners would overlap both temporally and spatially with resident trout spawners.

Rainbow trout, cutthroat trout, apparent hybrid trout (cutthroat $\mathrm{x}$ rainbow), spring chinook salmon, longnose and speckled dace, sculpin, bridgelip suckers, northern squawfish, and redside shiners were observed in the West Fork of the Teanaway River.

\section{MIDDLE FORK TEAMATAY}

Spawning surveys were conducted-in the Middle Fork of the Teanaway River on March 7, March 28, May 29, June 21, and June 24. High water, due to spring runoff in April and May, restricted sampling efforts and resulted in limited sample sizes. The percentage of sexually mature rainbow trout in this stream was high in both March (43\%) and June (55\%) and probably peaked during May (Figure 2). Water temperatures climbed from $6.5{ }^{\circ} \mathrm{C}$ in March to $10^{\circ} \mathrm{C}$ in June. 
A
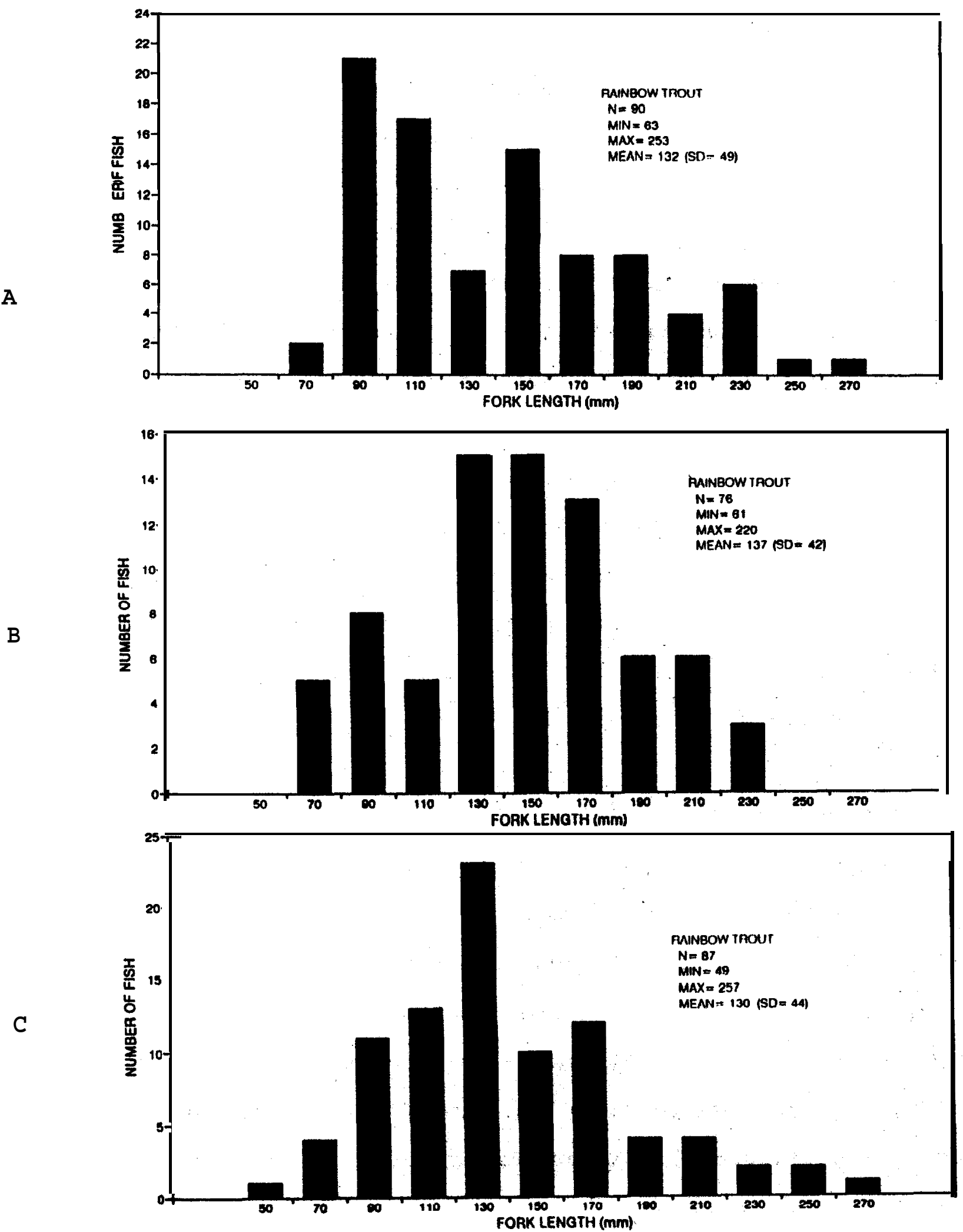

Figure 7. Length frequency histogram of rainbow trout captured fin the West Fork (A), Middle Fork (B), and North Fork (C) of the Teanaway River during spawning surveys in 1991. 
The percentage of sexually mature trout was similar among all three Middle Fork sections suggesting that spawning occurred throughout the length of stream sampled. Mean length increased with distance upstream although maximum length was very similar in all three sections (Table 1).

The mean length of rainbow trout in the Middle Fork was 137 $\mathrm{mm}$, although the hook and line methods used in June could have selected for larger fish. The length frequency distribution for the Middle Fork shows peaks in fish numbers at 90 and $130-150 \mathrm{~mm}$ (Figure 7B). Other species present included hatchery steelhead (age 1+), sculpins, dace, and suckers.

\section{NORTH FORK TEANAWAY}

Spawning surveys were conducted in the North Fork of the Teanaway River on March 8, May 28, May 30, and June 8, 12, 15, 18, 24, 25, and 28. The large number of surveys (particularly in June) coincided with the collection of spawning trout samples for genetic analyses. Water temperatures ranged from $3.5^{\circ} \mathrm{C}$ in $\mathrm{March}$ to $9{ }^{\circ} \mathrm{C}$ in June. The percentage of sexually mature resident trout remained high from March to June (similar to the other forks of the Teanaway) indicating a wide range of spawning timing (Figure 2).

The overall percentage of sexually mature rainbow trout in the North Fork was similar in all three sections sampled, 
suggesting that spawning occurred throughout the length of this tributary. Mean length of rainbow trout was largest in the uppermost section (Table 1). The length frequency for the North Fork shows two possible size classes at 130 and $170 \mathrm{~mm}$ (Figure 7c).

Rainbow, cutthroat, brook, and bull trout, as well as hatchery steelhead, wild steelhead, spring chinook salmon, mountain whitefish, longnose dace, sculpins, and bridgelip and largescale suckers were observed in the North Fork of the Teanaway River. A pair of wild steelhead were observed spawning in the North Fork Teanaway slightly upstream of the Dickey Creek Bridge on May 9, 1991.

\section{BIG CREEK}

Big Creek was sampled on three occasions; March 18, April 22, and May 31 with little success on each survey. A total of only 24 trout were captured of which only one was sexually mature. Only two of the 24 trout were large enough to be of spawning size (Table 1). A length frequency histogram was not developed due to limited sample size. High stream flows, low water conductivities, and possibly low population densities were the most likely factors accounting for the low number of trout captured. The low numbers of fish encountered may also have been related to the fact that the lower areas of this stream were dewatered during the fall in 1990. 
Water temperatures remained cool through the end of May. (6-8 $\left.{ }^{\circ} \mathrm{C}\right)$ suggesting that spawning may occur later than in other tributaries. In 1990, sexually mature trout were found in Big Creek as late as June 20 when the water temperature was $13{ }^{\circ} \mathrm{C}$ (Hindman et al. 1991).

Brook trout, apparent hybrid trout (cutthroat $x$ rainbow), and sculpins were observed in addition to rainbow trout.

\section{CABIN CREEK}

In November of 1990, a large flood caused massive scouring of the stream bed and deposited a considerable amount of material in the lower $4.8 \mathrm{~km}$ of Cabin Creek. From rkm 5.0 to 6.1 a series of cascades and small waterfalls form a complete barrier to upstream migration of anadromous fish. A spawning survey was conducted on March 18, and only three small rainbow trout were collected (mean length $=73 \mathrm{~mm} ;$ Table 1 ). Water temperature on March 18 was $5^{\circ} \mathrm{C}$ and was $9{ }^{\circ} \mathrm{C}$ on May 31. No trout were captured on May 31 due to high flow conditions. Flows were generally high, making this stream extremely difficult to sample. Also, access to the stream was hampered by numerous washouts of bridges and roads. A sexually mature female was collected in Cabin Creek on June 25, 1990, suggesting that spawning occurs late in this upper elevation tributary (Hindman et al. 1991). 


\section{CLE ELUM RIVER}

A snorkel survey was conducted on March 7 in the lower $\mathrm{Cle}$ Elum River near Bullfrog Bridge. Adult mountain whitefish ( $\mathrm{N}=$ 13) were sighted but no trout were observed, The lower $1.5 \mathrm{~km}$ of the Cle Elum River was electrofished with the driftboat on May 20. Whitefish and suckers were common but no trout were captured or observed on this survey either. Failure to detect resident trout in 1991 was similar to results of 1990. In 1990, a total of only 16 rainbow trout were sighted during two snorkel surveys (Hindman et al. 1991).

\section{Mainstem Yakima River}

LOWER CANYON (Section 1)

Spawning surveys in the Lower Canyon section of the mainstem were conducted on February 7, February 11, March 11, April 10, May 13, and May 29. Water temperatures recorded during sampling ranged from, $3.5^{\circ} \mathrm{C}$ in February to $11^{\circ} \mathrm{C}$ in May.

Time of spawning data suggests that peak spawning activity occurred in March (21\%), and declined in April (13\%) and May (2\%) (Figure 8). The numbers of rainbow trout classified as spent were highest during the April and May samples. This trend is similar to that observed in 1990 when none of the 65 trout captured during May surveys were sexually mature (Hindman et al. 
1991) .

A total of 205 rainbow trout were sampled in this section. Rainbow trout mean length ' (282 mm) was slightly larger than the pooled average for all mainstem sections (273 mm; Table 3). The length frequency distribution for the lower section showed a high proportion of the fish over $300 \mathrm{~mm}$, with the greatest number of fish in the $350 \mathrm{~mm}$ length class (Figure 9A). Hook-scarred. fish were common in the lower Canyon with 27\% of all rainbow trout sampled exhibiting some signs of hooking injuries (Table $3)$.

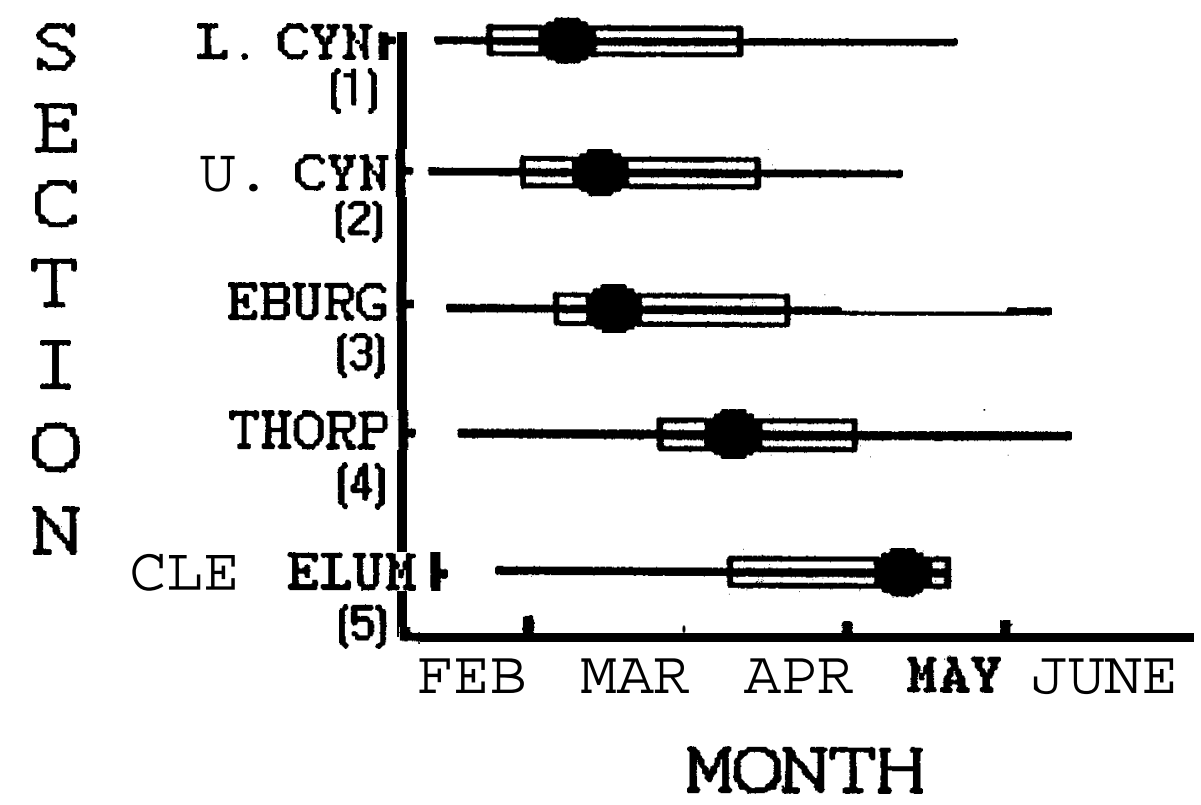

Figure 8. Spawning time of resident rainbow trout in the upper Yakima River during spawning surveys in 1991. Section numbers appear in parentheses below the corresponding section name. Dots show estimated peak of spawning activity, boxes denote periods when $10 \%$ or more of the fish sampled were sexually mature, thick lines show periods when one to nine percent of the fish were sexually mature, and thin lines cover periods when no fish in spawning condition were sampled. 
Table 3. Summary of rainbow trout captured in 1991 during spawning surveys of the mainstem Yakima River. Sample size (N), minimum (Min), maximum (Max), and mean length (Mean), standard deviation (SD), average condition factor (CF), percent sexually mature (Mature), and percent hook-scarred (Hook-scar) are presented.

\begin{tabular}{|c|c|c|c|c|c|c|c|c|}
\hline \multirow[b]{2}{*}{ Section } & \multirow[b]{2}{*}{$\mathbf{N}$} & \multicolumn{4}{|c|}{ Fork Ienath (nun) } & \multirow{2}{*}{$\underset{\mathrm{CF}}{\mathbf{A v g}}$} & \multicolumn{2}{|c|}{ Percent } \\
\hline & & Min & Max & Mean & SD & & Mature & Hook-scar \\
\hline Yak 1 & 205 & 88 & 460 & 282 & 76 & 0.74 & 16 & 27 \\
\hline Yak 2 & 196 & 118 & 450 & 293 & 64 & 0.72 & 11 & 27 \\
\hline Yak 3 & 96 & 92 & 440 & 271 & 85 & 0.77 & 10 & 16 \\
\hline Yak 4 & 105 & 102 & 475 & 225 & 94 & 0.79 & 15 & 8 \\
\hline Yak 5 & 114 & 73 & 448 & 265 & 103 & 0.82 & 10 & 17 \\
\hline Yak 6 & 20 & 102 & 498 & 299 & 110 & 0.80 & 24 & 0 \\
\hline Yak $7^{\star}$ & & & & & & & & \\
\hline POOLED & 736 & & & 273 & & 0.76 & 13 & 21 \\
\hline
\end{tabular}

no rainbow trout captured

Other fishes observed in this section were, in approximate order of abundance, mountain whitefish, suckers, northern squawfish, sculpins, chiselmouth, redside shiners, and dace.

UPPER CANYON (Section 2)

The Upper Canyon section of the Yakima River was surveyed on February 5, February 12, March 12, April 12, and May 13. A total of 196 rainbow trout were collected. The mean length of these 
fish was $293 \mathrm{~mm}$, which was slightly larger than the average for all mainstem sections pooled (273 mm; Table 3).

Spawning activity appeared highest in March (21\% sexually mature) followed by declines in April (13\%) and May (2\%) (Figure 8). This trend is similar to that observed in 1990 (Hindman et al: 1991), when a single spawning female was sampled on February 21, and $11 \%$ of the sampled fish were considered to have already spawned on a subsequent survey in May, 1990. In 1991, three spent adult rainbow trout were observed in April, while 12 of 23 adult rainbows (52\%) were spent in May. Water temperatures ranged from $4{ }^{\circ} \mathrm{C}$ in February to $11^{\circ} \mathrm{C}$ in May.

The length frequency distribution of rainbow trout in the Upper Canyon section shows a wide range of age classes (Figure 9B) .

It is evident that resident trout do spawn in the mainstem Yakima River in this section. However, use of periodic electrofishing surveys makes it difficult to determine the specific temporal and spatial distribution of concentrated spawning activity in this large river.

Other species observed, in approximate order of abundance, were mountain whitefish, suckers, northern squawfish, sculpins, chiselmouth, and dace. 
A

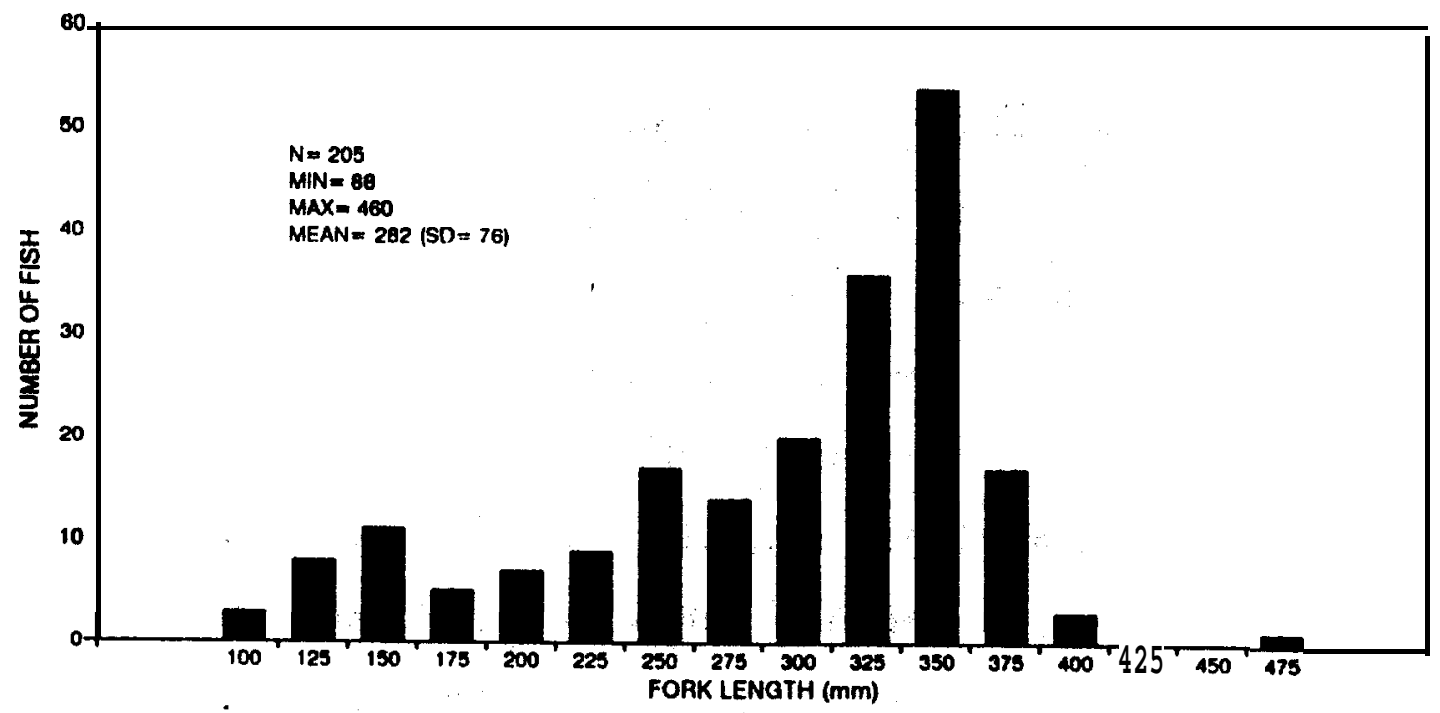

B

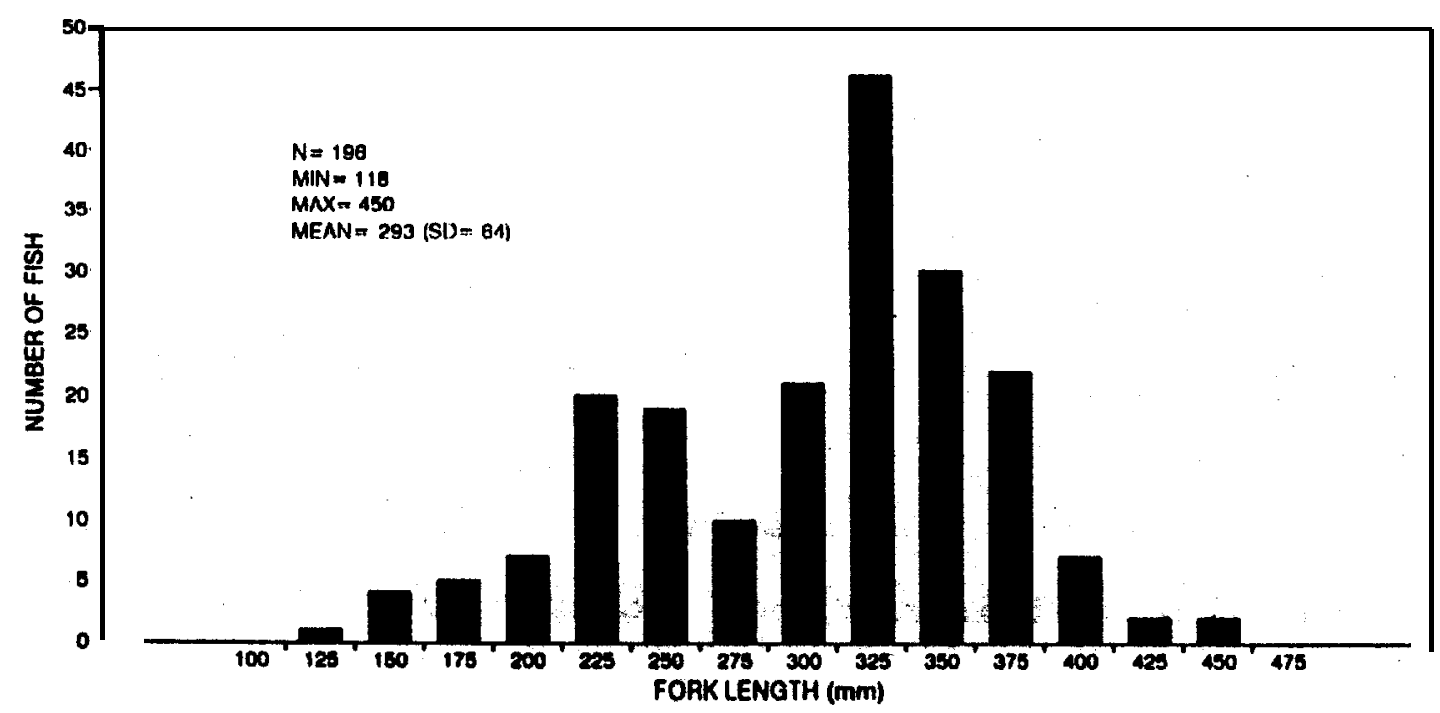

Figure 9. Length frequency histograms of rainbow trout captured in Lower Canyon (A), and Upper Canyon River during spawning surveys in 1991.

(B) sections of the Yakima

\section{ELLENBbURO (Beotion 3 )}

The Ellensburg section of the Yakima River was surveyed on February 13, March 13, April 11, May 15 and June 6. The percentage of sexually mature rainbow trout was highest in March. 
(22\%), followed by declines in May (0\%) and June (4\%). This trend was similar to the results of spawning surveys in upstream sections (Figure 8).

The length frequency distribution for this section reflected a wide range of age classes and was not distinctly bimodal as in the case of the Cle Elum and Thorp sections (Figure 10A). Mountain whitefish, suckers, northern squawfish, sculpins, and dace were also observed in this section.

THORP (SECTION 4)

The Thorp section of the mainstem Yakima River was surveyed on February 14, March 14, April 9, and June 10. Sexual maturity of sampled trout increased through April (27\%) and declined by June (6\%) (Figure 8). A large percentage of spent fish (47\%) were observed in June, suggesting spawning was mostly completed.

The length frequency distribution for rainbow trout was bimodal (Figure 1OB). The mean length of rainbow trout in the Thorp section $(225 \mathrm{~mm})$ was the smallest of any river section surveyed (Table 3).

In approximate order of abundance, other fishes observed were mountain whitefish, suckers, northern squawfish, sculpins, and dace. 
A

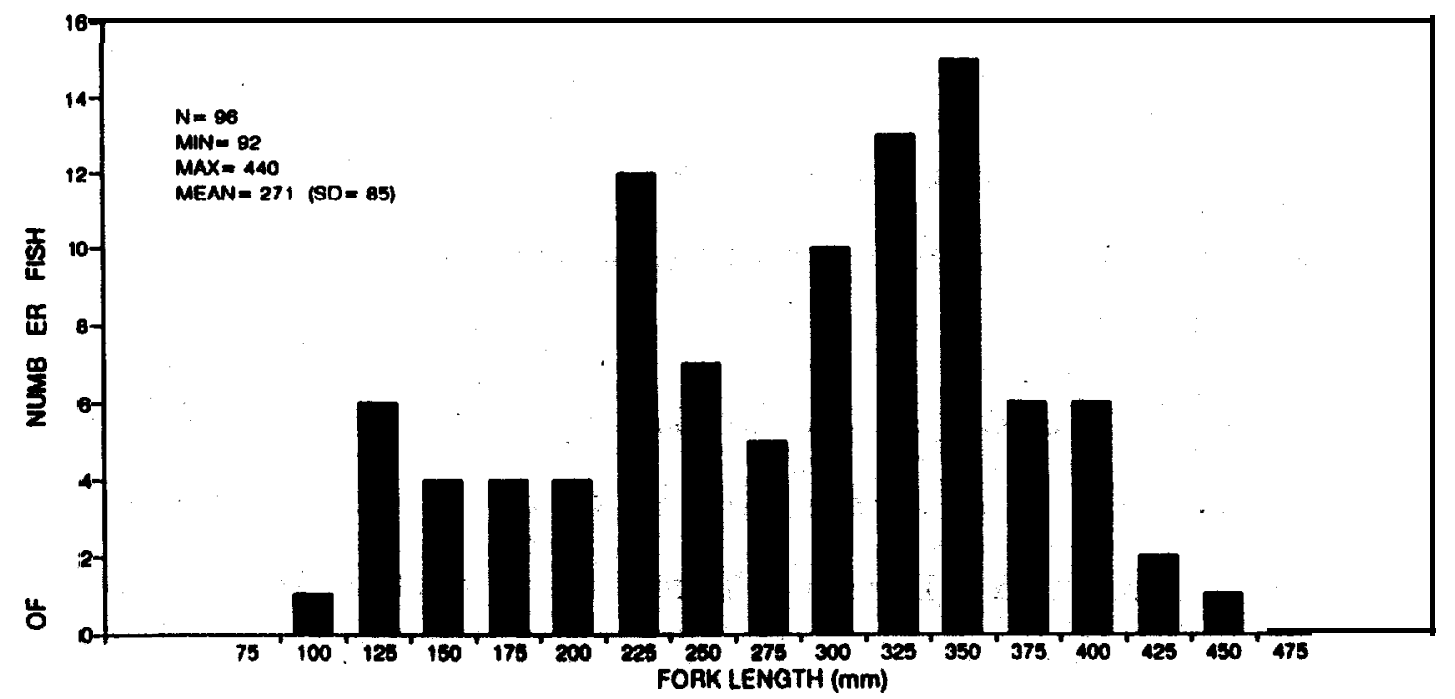

B
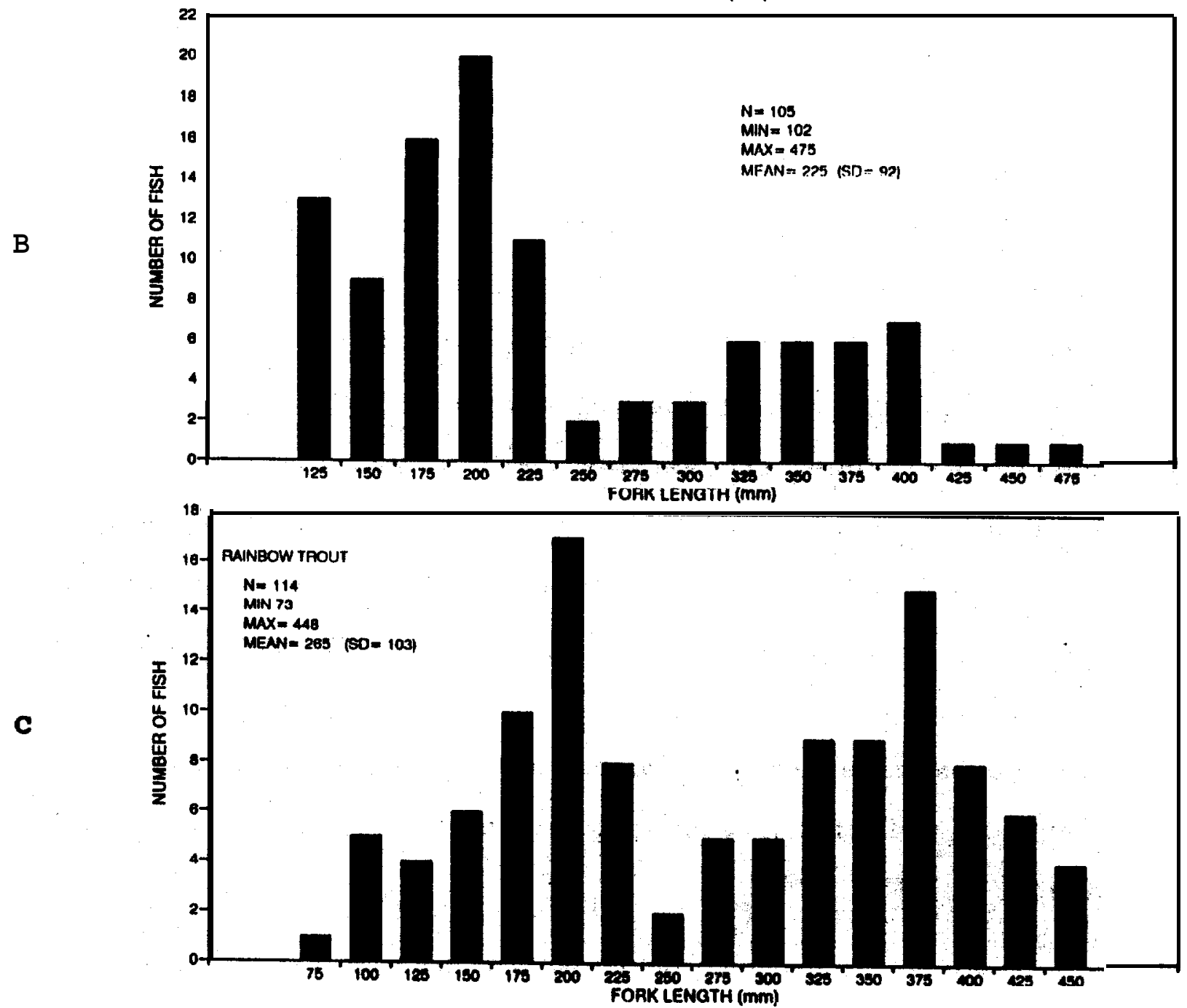

Figure 10. Length frequency histograms of rainbow trout captured in Ellensburg (A), Thorp (B), and Cle Elum (C), sections of the Yakima River during spawning surveys in 1991. 


\section{CLE ELUM (Seotion 5)}

The Cle Elum section of the Yakima River was surveyed on February 26, March 15, May 20, and May 24. The percent of sexually mature rainbow trout observed was highest in late May (27\%) and declined sharply less than a week later (6\%) (FIgure 8). A large percentage (31\%) of the adult fish sampled in the Cle Elum section during May surveys were spent.

The length frequency distribution for rainbow trout sampled in the Cle Elum section showed a clear bimodal distribution (Figure 10C). The mean length (265 nun) for fish in this section was slightly lower than that observed for the average of all mainstem sections combined-(273 mm; Table 3).

Of the other species observed, mountain whitefish were the most plentiful, followed in order by suckers, northern' squawfish, and sculpins.

\section{NELBON SIDING (Bection 6)}

The Nelson Siding section of the mainstem Yakima River was surveyed with the driftboat electrofisher for the first time ever on February 28, 1991. Ten large rainbow trout were captured (max $=498 \mathrm{~mm}$; Table 3), of which four were mature males and one was a mature female. Hook and line sampling on June 28 produced nine rainbow trout. Of these, none were classified as mature and two were classified as spent. A large number of rainbow trout $(\mathrm{N}=$ 245) were observed in this section during snorkeling surveys 
during the spawning period in 1990 (Hindman et al. 1991). Although sample size was small $(N=20)$, the mean length of rainbow trout (299 $\mathrm{mm} \mathrm{FL}$ ) was the largest of any mainstem section sampled in 1991 . In addition, the largest trout captured during 1991 spawning surveys was in this section (498 mm; Table 3). A length frequency distribution is not presented due to a very small sample size. It is difficult to determine when spawning peaked with the data collected thus far.

Spawning adult steelhead were observed on redds in this section on April 30, 1991. Brook trout, mountain whitefish, suckers, northern squayfish, and sculpins were also observed in this section.

\section{CRYSTAL SPRING8 (SECTION 7)}

The Crystal Springs reach of the mainstem is the uppermost section studied. A spawning survey in this section on May 16, resulted in capture of only one brook trout. An additional survey was conducted on June 12, below the Interstate 90 bridge, when 14 brook trout were captured along with one cutthroat and one putative cutthroat $\mathbf{x}$ rainbow trout hybrid. Electrofishing efficiency in this area appeared to be marginal due to high river flows and low water conductivities (< 100 mmos/cm).

This stretch of the Yakima River is subjected to extreme flow fluctuations from irrigation releases mad8 at Keechelus Dam. For example, flows in the Yakima River below Keechelus Dam 
tripled from 10.5 to $30.3 \mathrm{~m}^{3} / \mathrm{s}$ in a 24 hour period on June 5, 1990 (USBR, unpub. data). Flow fluotuations of similar magnitude occur several times each year and may be a major contributor to the low abundance of fish observed in this reach.

\section{spawning Survey Summary}

\section{Tributaries}

Rainbow trout spawning activity in lower elevation tributaries (Umtanum, Badger, Cherry, and Wilson creeks) peaked earlier in the spring than in tributaries at higher elevations. Earlier spawning at low elevation may be related to the water temperatures warming earlier in the year in these lower elevation areas than in the more mountainous streams at higher elevations (Figure 2). Hindman et al. (1991) also observed rainbow trout in lower elevation areas spawning earlier than those in areas in 'the upper portion of the basin.

Large numbers of mainstem Yakfma River rainbow trout migrated into Umtanum Creek to spawn. This creek is the only perennial tributary in'the Yakima Canyon area and appears to be a very important spawning stream for trout.

Trout in the lower tributaries were generally larger than their counterparts in the upper elevation streams. Wilson Creek 
trout were, on average, largest and carried the highest mean total number of eggs and the highest mean number of eggs per millimeter of body length. Fecundity was positively correlated with trout body length $(\mathrm{N}=38, \mathrm{R}=0.786, \mathrm{P}=0.000)$ and weight $(\mathrm{N}=35, \mathrm{R}=0.949, \mathrm{P}=0.000)$ for fish collected in tributaries.

\section{Mainstem}

Rainbow trout in the mainstem Yakima River spawned earlier in low elevation sections than in high elevation sections (Figure 8). Water temperature may again be an important environmental cue related to this difference in spawn timing.

Trout in the Nelson Siding reach (section 6) and those captured in the Yakima Canyon sections (1 and 2) were, on average, larger than fish in the middle reaches (from cle Elum to Ellensburg). Condition factors (a length to weight relationship) were generally higher for the fish sampled in the upper elevation areas and'decreased with distance downstream.

Fecundity data was collected from 19. female rainbow trout

from the Yakima River mainstem with a mean length of $342 \mathrm{~mm}$. The mean number of eggs per female was 982 , and the mean number of eggs per millimeter of body length was 2.9. Trout from two tributaries (Wilson and Badger creeks) had higher fecundity than mainstem fish, while trout from three others (Umtanum, Manastash, and Taneum creeks) had, on average, fewer eggs. 
During the course of conducting spawning surveys for rainbow trout in the upper basin from steelhead spawners were observed on April 30 (Nelson Siding; section 6) and on May 9 (North Fork of the Teanaway River). In addition, suspected steelhead redds were located in two side-channels of the Cle Elum reach (section 5) by YIN in April, 1990 (J. Hubble, pers. comm.). These observations, although limited, indicate areas of possible temporal overlap between steelhead and rainbow trout spawners.

\section{REARING BURVEYS}

Population Estimates

Population estimates in mainstem and tributary sections provide quantitative information on the resident trout' populations during, the summer-fall rearing season. These estimates afford the opportunity to gain detailed-information on the rearing segments of the trout populations within index areas of selected tributaries and mainstem sections. This data is useful.for making comparisons between years within the same area and for contrasting between areas. This baseline information, along with findings from the more qualitative relative abundance surveys, will serve as a standard by which to measure future change in the trout resource in the upper Yakima basin. This section of the report contains data collected during the summer- 
fall periods of both 1990 and 1991, whereas the relative abundance section that follows was conducted for the first time in 1991.

\section{Methods}

\section{Tributaries}

To obtain quantitative information on densities of stream rearing fishes in the upper Yakima River basin, tributaries were identified-in 1990 which generally satisfied two criteria: 1) streams most likely to contain resident trout populations that could be affected by returns of supplemented fish, and 2) streams with proposed acclimation facilities (which release artificiallyproduced fish). This process resulted in the selection of five study streams: Cabin Creek, Taneum Creek, and the West, Middle and North forks of the Teanaway River (Figure 1). An additional site (lower Jungle Creek) was selected in 1991 to compliment smolt release experimentation (see Smolt Release Study, this report). Within these tributaries (with the exception of Jungle Creek), multiple sites were selected that were visually determined to be of relatively high quality in terms of available habitat, representative of the stream as a whole, and identifiable so that between-year comparisons could be made. The site selection process generally began with establishment of the lower elevation site, followed by the upper elevation site, and 
finally the intermediate site (if any) near the mid-point. Study sites were staked and marked in 1990 for use in that and subsequent years. In 1991, markers for the upper West Fork Teanaway site could not be located due to catastrophic changes in the stream channel following flood conditions in November of 1990. Therefore, markers were replacedslightly upstream of the original area prior to surveying in 1991. Study sites were established to encompass representative habitat units (e.g. pools, riffles, runs) but were generally about $100 \mathrm{~m}$ long.

Fish population estimates were conducted in three sites in Taneum Creek and in each of the three forks of the Teanaway River. Only two sites were established in Cabin Creek because of the uniformity of habitat and the short distance of stream available to anadromous fish.

Fish population estimates were calculated using multiple removal electrofishing methods (zippin 1958). Data were analyzed using a personal computer program (Microfish 3.0; VanDeventer and Platts 1985). Block nets of $6.35 \mathrm{~mm}$ knotless nylon mesh were used to preclude immigration and emigration from the study section. All fish were enumerated during the first pass with the electrofisher. This allowed direct comparison with relative abundance methods that were used on other streams (see Relative Abundance Surveys, this report). On subsequent passes only salmonids were enumerated. 
All captured fish were identified as to species and counted. All salmonids were measured to the nearest millimeter and weighed to the nearest gram. Trout over $175 \mathrm{~mm}$ long received a serially numbered anchor tag on the left side near the posterior margin of the dorsal fin. During 1990, trout between 120 and.175 mm (FL) captured in the Teanaway River system received serially numbered dangler-type fingerling tags inserted near the anterior edge of the dorsal fin. In 1991, fish of this size received a numerically unique VI tag placed subcutaneously in the left adipose eyelid. Before enumeration and tagging, MS-222 was added to a bucket of water to anesthetize the fish. Scale samples were collected from a cross section of rainbow trout length classes (N = 50) in each tributary. All trout were examined for previously applied tags and evidence of hooking injuries (hook-scars). After processing, all fish were transferred into a perforated bucket for recovery, so they could be redistributed within the population site.

Physical data collected included stream temperatures $\left({ }^{\circ} \mathrm{C}\right)$ and water conductivity. Water velocity was also measured in meters/second using a Marsh-McBirney Model 201D portable current meter. Measurements were normally taken laterally at $0.5 \mathrm{~m}$ increments along a metric tape stretched between streambanks. Velocities per unit area were later computed and summed to estimate total discharge in cubic meters per second $\left(\mathrm{m}^{3} / \mathrm{s}\right)$. 
Area of each habitat unit (pools, riffles and runs) within each site were measured using methods similar to Bisson et al. (1982). A metric stadium was used to measure. the maximum depth of individual habitat units. Habitat units were further subdivided as follows; riffles: low gradient, rapid, cascade; pools: bottom scour, lateral scour, plunge, dam, trough, and back water; runs. Photographs were taken of select study sites for reference and archive purposes.

\section{Mainstem. Yakima River}

Population estimates were conducted in five of the seven index sections of the Yakima River mainstem. The location and nomenclature for these sections correspond to the broader areas in which spawning surveys were conducted. Index sections were established based on the location of suitable access sites and satisfaction of a $4 \mathrm{~km}$ minimum length criteria. A description of specific index sites follows: Lower Canyon, section 1, Squaw Creek to the cement slab access; Upper Canyon, section 2, Ringer Road access to Bighorn access; Ellensburg, section 3, KOA RV park to Irene Reinhart Park; Thorp, section 4, Stuart Anderson's homestead to Thorp Bridge; Cle Elum, section 5, from a site adjacent to Cle Elum to the Teanaway Department of Wildlife access area (Figure 1). Section 6 (Nelson Siding), from Easton Dam to the mouth of the Cle Elum River, and section 7 (Crystal Springs), Keechelus Dam to Easton Reservoir, were not suited to 
driftboat electrofishing (due to channel obstructions -and/or low flow) and snorkeling techniques were used instead. Snorkeling techniques did not allow a strict population estimate to be generated, but did provide an indication of species occurrence and relative abundance (Goldstein 1978; Schill and Griffith 1984; Zubik and Fraley 1988).

Population estimates were conducted after summer irrigation flows were reduced. Surveys were conducted between October 4 and November 8 in 1990, and between September 16 and November 14 in 1991. Mark-recapture techniques (Vincent 1971) were used to estimate population size. An electrofishing driftboat was used at night to increase sample sizes (Loeb 1957). Each population estimate consisted of making four passes; a run on each side of the river on consecutive nights to mark fish (small fin-clip), and another run on each side of the river one week later to recapture marked fish and collect unmarked fish.

The driftboat electrofishing equipment was modified slightly between 1990 and 1991. In 1990, the driftboat was equipped with a mobile anode system. This anode was attached by an extension cord to the power source and tossed into potential trout habitat and retrieved slowly to the driftboat. This process continued repeatedly while drifting downstream. Trout exhibited galvanotaxis as they were affected by the electrical current and moved toward the driftboat where a netter collected the fish and placed them in a live-box in the boat. Operation of the mobile 
anode system required three people; a rower, a netter, and an anode handler. 'In 1991, the mobile anode was changed to a stationary anode to improve capture effectiveness, enable the use of a low-injury electrofisher setting (CPS by Coffelt), and reduce the number of people required for sampling, Use of the stationary anode system required only two people; a rower and a netter. The stationary anode consisted of a $15.7 \mathrm{~cm}$ diameter "Wisconsin ring", which was suspended in the water over the bow of the'boat by a fiberglass and aluminum boom. In both applications (mobile and stationary anode) an aluminum plate attached to the hull of the boat served as the cathode.

The crew stopped at regular intervals to record information from the fish that had been collected. The number of stops per section was increased in 1991 (from two or three in 1990 to four per night in 1991) to allow for better redistribution of fish following the marking runs. Efforts were made to release fish in slow, shallow areas in 1991 to encourage the fish to redistribute from the releases site. Data collection methods were similar to those described in the spawning survey section (see Spawning Surveys, this report). In addition to collection of biological data, all trout captured during the marking runs were given .a temporary fin clip unique to the section being sampled.. After handling, fish were put in a mesh holding pen in quiet water to allow them to recover from the anesthetic before being released back into the river. Population estimates were generated using 
the Montana Department of Fish, Wildlife and Parks Mark-Recapture System (version 3.1), a PC-based computer program based on the Petersen mark-recapture methodology.

In mainstem sections 6 and 7 , numerous channel obstructions (extensive log jams) prohibited the use of the driftboat electrofishing system so snorkeling techniques were used. Two snorkelers, one on each side of the channel (mean width was about 10 meters), floated downstream counting all fish observed. Observed trout were divided into two size groups, $>150 \mathrm{~mm}$ and $\leq 150 \mathrm{~mm}$ based on approximate size groupings for adult and juvenile trout, respectively.

\section{Results and Discussion}

\section{Tributaries}

\section{TAYEUx $C R E E K$}

Trout density (number of trout per unit area) was highest in the lowermost site in Taneum Creek during both 1990 and 1991 (Table 4). Biomass $(\mathrm{g} / \mathrm{m} *)$ in Taneum Creek increased with distance upstream and was, on average, higher in 1991 than in 1990. The salmonid communities in the lower and intermediate sites were dominated by rainbow trout. The uppermost section had the highest number of salmonid species present. Rainbow trout 
Table 4. Population estimates (95\% confidence intervals), number of fish per square meter $\left(* / \mathrm{m}^{2}\right)$, biomass $\left(\mathrm{g} / \mathrm{m}^{2}\right)$, and percent species composition for 1990 and 1991 fall tributary. rearing surveys. Average values (MEANS) are shown for each tributary, with the years and sections pooled. Lower numbered sites are lower in elevation within a given tributary.

\begin{tabular}{|c|c|c|c|c|c|c|c|c|c|c|c|c|c|}
\hline \multirow{2}{*}{\multicolumn{3}{|c|}{$\begin{array}{l}\text { Year } \\
\text { stream, section }\end{array}$}} & \multirow{2}{*}{\multicolumn{2}{|c|}{$\begin{array}{cc}\text { Pop. } & \text { Eet. } \\
(95 \% & \text { CI })\end{array}$}} & \multirow[b]{2}{*}{$* / \mathrm{m}^{2}$} & \multirow[b]{2}{*}{$\mathrm{g} / \mathrm{m}^{2}$} & \multicolumn{7}{|c|}{ P ercelt } \\
\hline & & & & & & & RBT & BSH & CUT & $\mathbf{E B}$ & EYB & BUL & SPC \\
\hline 1990, & TAN & $1 \mathrm{~A}$ & 37 & $(32-47)$ & 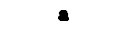 & & 97 & & 3 & & & & \\
\hline 1990 & TAN & $1 \mathrm{~B}$ & 48 & $(35-73)$ & - & . & 97 & & 3 & & & & \\
\hline 1990 & TAN & 2 & 60 & $(53-71)$ & 0.10 & 2.23 & 100 & & & & & & \\
\hline 1990 & TAN & 3 & 52 & $(40-73)$ & 0.09 & 1.89 & 33 & & 27 & 13 & 27 & & \\
\hline 1991, & TAN & $1^{b}$ & 167 & $(78-322)$ & 0.28 & 3.24 & 100 & & & & & & \\
\hline 1991 & TAN & 2 & 49 & $(47-54)$ & 0.09 & 2.93 & 94 & & & 6 & & & \\
\hline 1991, & TAN & 3 & 39 & $(34-49)$ & 0.07 & 2.12 & 43 & & 20 & 17 & 20 & & \\
\hline MEAN & & & 65 & & 0.13 & 2.48 & 81 & & 8 & 5 & 7 & & \\
\hline 1990, & WrT & 1 & 109 & $(82-142)$ & 0.16 & 1.54 & 79 & & & & & & 21 \\
\hline 1990 & WFT & 2 & 38 & $(33-49)$ & 0.05 & 0.82 & 92 & & & & & & 8 \\
\hline 1990 & WF'T & 3 & 15 & $(15-17)$ & 0.02 & 0.49 & 100 & & & & & & \\
\hline 1991 & WF'T & 1 & 107 & $(82-137)$ & 0.19 & 0.82 & 100 & & & & & & \\
\hline 1991 & WFT & 2 & 63 & $(58-71)$ & 0.09 & 1.78 & 98 & & 2 & & & & \\
\hline 1991 & WPT & 3 & 52 & $(43-68)$ & 0.06 & 0.53 & 100 & & & & & & \\
\hline MEAN & & & 64 & & 0.10 & 1.05 & 95 & & $<1$ & & & & 5 \\
\hline 1990 & MF'T & 1 & 84 & $(70-101)$ & 0.15 & 2.23 & 60 & & & & & & 40 \\
\hline 1990 & MTT & 2 & 114 & $(102-128)$ & 0.17 & 3.43 & 95 & & 1 & & & & 4 \\
\hline 1990 & WFT & 3 & 80 & $(72-92)$ & 0.13 & 2.37 & 99 & & 1 & & & & \\
\hline 1991 & MFT & 1 & 121 & $(98-148)$ & 0.21 & 1.80 & 99 & & & & 1 & & \\
\hline 1991, & HFT & 2 & 181 & $(148-213)$ & 0.30 & 1.75 & 99 & & 1 & & & & \\
\hline 1991, & MFT & 3 & 57 & $(51-67)$ & 0.09 & 1.85 & 98 & & & & 2 & & \\
\hline MEAI & & & 106 & & 0.18 & 2.24 & 92 & & $<1$ & & $<1$ & & 7 \\
\hline
\end{tabular}




\begin{tabular}{|c|c|c|c|c|c|c|c|c|c|c|c|c|c|}
\hline 1990, & NET & 1 & 80 & $(64-104)$ & 0.07 & 0.54 & 45 & & & & & & 55 \\
\hline 1990, & NET & 2 & 75 & $(55-105)$ & 0.10 & 1.82 & 100 & & & & & & \\
\hline 1990, & NFT & 3 & 57 & $(50-69)$ & 0.11 & 4.71 & 11 & & 73 & & 5 & 11 & \\
\hline 1991,1 & NFT & 1 & 79 & $(59-107)$ & 0.09 & 1.17 & 93 & 5 & & & 2 & & \\
\hline 1991, & NFT 2 & 2 & 42 & $(33-60)$ & 0.06 & 0.86 & 88 & 9 & & & 3 & & \\
\hline 1991, & NFT & 3 & 21 & $(18-30)$ & 0.04 & 2.40 & 22 & 6 & 72 & & & & \\
\hline MEAN & & & 59 & & 0.08 & 1.92 & 60 & 3 & 24 & & 2 & 2 & 9 \\
\hline 1990, & $\mathrm{CAB}$ & 1 & 11 & $(11-12)$ & 0.02 & 0.80 & 18 & & & 55 & 9 & & 18 \\
\hline 1990, & CAR 2 & 2 & 24 & $(24-25)$ & 0.04 & 1.49 & 54 & & 21 & 13 & 8 & & 4 \\
\hline 1991, & $\mathrm{CAB}$ & 1 & 30 & $(26-40)$ & 0.05 & 0.81 & 86 & & & 14 & & & \\
\hline 1991, & CAB 2 & 2 & 21 & $(18-30)$ & 0.04 & 1.49 & 100 & & & & & & \\
\hline MEAN & & & 22 & & 0.04 & 0.83 & 65 & & 5 & 21 & 4 & & 5 \\
\hline
\end{tabular}

- Habitat areas were not measured in these individual sites in 1990.

b Taneum 1 was created in 1991 by combining sites 1A and 1B used in 1990. Abbreviations for streams are as follows: CAB = Cabin Cr., TAN.- Taneum Cr., WFT = West Fork of the Teanaway River, MFT. = Middle Fork of the Teanaway River, NFT $=$ North Fork of the Teanaway River.

were the most abundant species of salmonid in this upper section (Table 4). Mean lengths were $110,130,166$, and $123 \mathrm{~mm}$ for rainbow, hybrid, cutthroat, and brook trout, respectively (sections and years pooled).

Habitat composition in Taneum Creek study sections varied little between years (Table 5). Water temperatures were slightly cooler, surface area was greater, and flows were higher in 1991 than they were the previous year (Table 5). These conditions may be partially responsible for the higher biomass observed in 1991 . 
Table 5. Habitat measurements (percent pool, riffle, run), water temperature $\left({ }^{\circ} \mathrm{C}\right)$ at time of survey, total area $\left(\mathrm{m}^{2}\right)$, and flow $\left(\mathrm{m}^{3} / \mathrm{s}\right)$ for tributary population estimate sites in the upper Yakima River basin during the summer-fall periods of 1990 and 1991. Mean values (MEANS) are shown for each tributary, years and sections pooled. Lower numbered sites are lower in elevation within a given tributary.

\begin{tabular}{|c|c|c|c|c|c|c|c|c|c|}
\hline \multirow{2}{*}{\multicolumn{3}{|c|}{$\begin{array}{l}\text { Year } \\
\text { Stream, }\end{array}$}} & \multicolumn{4}{|c|}{ Percent } & \multirow[b]{2}{*}{ Temp } & \multirow[b]{2}{*}{ Area } & \multirow[b]{2}{*}{ Flow } \\
\hline & & & & Pool & Riffle & Run & & & \\
\hline 1990 & Taneum & $1 A \& 1 B$ & & 36 & 25 & 39 & 17 & 615 & 0.37 \\
\hline 1990 & Taneum & 2 & & 20 & 46 & 34 & '12 & 608 & 0.50 \\
\hline 1990 & Taneum & 3 & & 6 & 26 & 68 & 10 & 568 & 0.30 \\
\hline 1991, & Taneum & 1 & & 42 & 44 & 14 & 16 & 600 & 0.32 \\
\hline 1991, & Taneum & 2 & & 13 & 33 & 54 & 15 & 561 & 0.39 \\
\hline \multirow[t]{2}{*}{ 1991, } & Taneum & 3 & & 4 & 58 & 38 & 15 & 521 & 0.25 \\
\hline & & MEANS & & 20 & 39 & 41 & 14 & 579 & 0.36 \\
\hline 1990, & W. Fk. & Teanaway & 1 & 5 & 63 & 32 & 13 & 678 & 0.07 \\
\hline 1990 & W. Fk. & Teanaway & 2 & 21 & 20 & 59 & 16 & 781 & 0.08 \\
\hline 1990 & W. Fk. & Teanaway & 3 & 10 & 57 & 33 & 12 & 631 & 0.10 \\
\hline 1991, & W. Fk. & Teanaway & 1 & 0 & 40 & 60 & 16 & 552 & 0.15 \\
\hline 1991, & W. Fk. & Teanaway & 2 & 16 & 38 & 46 & 18 & 699 & 0.14 \\
\hline \multirow[t]{2}{*}{ 1991, } & W. Fk. & Teanaway & 3 & 18 & 20 & 62 & 16 & 843 & 0.14 \\
\hline & & MEANS & & 12 & 40 & 48 & 15 & 697 & 0.11 \\
\hline 1990 & M. Fk. & Teanaway & 1 & 51 & 19 & 30 & 14 & 566 & 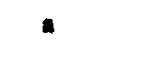 \\
\hline 1990 & M. Fk. & Teanaway & 2 & 12 & 64 & 24 & 13 & 683 & 0.08 \\
\hline 1990 & M. Fk. & Teanaway & 3 & 28 & 37 & 35 & 10 & 627 & 0.09 \\
\hline
\end{tabular}


Table 5. continued

\begin{tabular}{|c|c|c|c|c|c|c|c|c|}
\hline 1991, & M. Fk & Teanaway & 119 & 42 & 39 & 13 & 576 & 0.08 \\
\hline 1991, & M. Fk & Teanaway & 5 & 36 & 59 & 15 & 598 & 0.09 \\
\hline \multirow[t]{2}{*}{1991} & M. Fk. & Teanaway & 316 & 33 & 51 & 12 & 655 & 0.08 \\
\hline & & MEANS & $' 22$ & 39 & 39 & 13 & 618 & 0.08 \\
\hline 1990, & N. Fk & Teanaway & 115 & 16 & 69 & 5 & 1164 & 0.55 \\
\hline 1990, & N. Fk & Teanaway & 2 & 26 & 69 & 9 & 766 & 0.28 \\
\hline 1990, & N. ' $\mathbf{F k}$. & Teanaway & 23 & 44 & 33 & 10 & 519 & 0.64 \\
\hline 1991, & N. Fk & Teanaway & 0 & 37 & 63 & 12 & 863 & 0.64 \\
\hline 1991, & N. Fk & Teanaway & 0 & 28 & 72 & 8 & 726 & 0.42 \\
\hline \multirow[t]{2}{*}{ 1991, } & $\mathbf{N} . \mathbf{F} \mathbf{k}$ & Teanaway & 7 & 54 & 39 & 9 & 491 & 0.20 \\
\hline & . & MEANS & 8 & 34 & 58 & 9 & 755 & 0.46 \\
\hline 1990 & Cabin 1 & 1 & 21 & 19 & 60 & 10 & 471 & 0.12 \\
\hline ' 1990, & Cabin 2 & 2 & 10 & 59 & 31 & 10 & 679 & - \\
\hline 1991, & Cabin 1 & 1 & 14 & 66 & 20 & 18 & 664 & 0.16 \\
\hline \multirow[t]{2}{*}{ 1991, } & Cabin 2 & 2 & 0 & 78 & 22 & 12 & 499 & 0.18 \\
\hline & & MEANS & 11 & 56 & 33 & 13 & 578 & 0.15 \\
\hline
\end{tabular}

No flow measurement available.

In addition to salmonids, all three Taneum Creek sites contained an abundance of sculpins $\left(0.05\right.$ to $\left.0.12 / \mathrm{m}^{2}\right)$ in 1991 . The relative density of sculpins increased with distance upstream. 
WEST PORK OF TEB TEAMAIAY RIVER

Population densities $\left(* / \mathrm{m}^{2}\right)$ were highest in the lowermost section of the West Fork of the Teanaway River in 1990 and 1991 (Table 4). Juvenile spring chinook salmon made up 21\% of the salmonids by number in this lower section in 1990 but were not observed in 1991. Severe flooding subsequent to spring chinook spawning activity in late 1990 (after the 1990 estimates had been conducted), may have increased chinook egg mortality significantly. Biomass $\left(\mathrm{g} / \mathrm{m}^{2}\right)$ decreased in the lowermost site of the West Fork between 1990 and 1991, possibly-due to the total absence of juvenile spring chinook salmon (Table 4). There wae, however, no significant change in overall biomass for all sections pooled between the two years. Mean lengths of rainbow trout (92 mm) and juvenile spring chinook (89 mm) were fairly similar, while cutthroat trout were much larger (148 mm).

Population estimate sites in the West Fork of the Teanaway River contained. a variety of habitats. The lowermost site was predominantly riffle and run, with very little pool habitat (5 and $0 \%$ for 1990 and 1991, respectively), whereas the middle and upper sites contained relatively more pool habitat (10 to $21 \%$; Table 5). Water temperatures were slightly warmer in 1991, even though flows were slightly higher during the previous year. Other fishes observed in the West Fork of the Teanaway River during 1991 surveys were dace, sculpin, redside shiners, 
suckers, and northern sguawfish. Suckers and sguawfish were relatively uncommon $\left(0.05\right.$ to $\left.0.11 / \mathrm{m}^{2}\right)$ while sculpins, dace, and shiners were more abundant $\left(0.14\right.$ to $\left.2.23 / \mathrm{m}^{2}\right)$.

\section{MIDDLE FORK OF THE TEAIAWAY RIVER}

Average population densities of salmonids were higher in the Middle Fork of the Teanaway River than in any of the other tributaries sampled. There were an estimated 0.18 salmonids per square meter in this tributary (sites and years were pooled) (Table 4). Juvenile spring chinook comprised $40 \%$ of the salmonids in the lower site in 1990 but were absent in 1991, as was seen in the adjacent West Fork of the Teanaway River. Apart from the chinook in the lower two sites in 1990, the Middle Fork salmonid community was dominated by rainbow trout. Average length of rainbow trout $(97 \mathrm{~mm})$ was slightly larger than it was in the West Fork (92 mm), while the mean lengths of spring chinook salmon, cutthroat trout, and apparent hybrid trout were 91, 99, and $130 \mathrm{~mm}$, respectively, for sites and years pooled. Numerical density actually increased in two of the three sites, but mean length of the fish was considerably smaller in 1991, resulting in decreases in biomass in all sites from 1990 to 1991 (Table 5). For example, mean length of rainbow trout in the middle site -of the Middle Fork of the Teanaway in 1990 was 117 $\mathrm{mm}$, while the average rainbow trout captured there in 1991 was 
only $73 \mathrm{~mm}$ long. This reduction in mean length may suggest that the majority of the fish present in 1991 were age 0+, and that many of the older fish seen in 1990 were no longer present in 1991.

Stream channel morphology in the Middle Fork of the Teanaway River basin changed drastically between years, due primarily to the flood in late 1990. For example, the percent of pools in the lower site in 1990 was 51\%, while in 1991 it was only 19\% (Table 5). This reduction in pools, as well as more direct effects of the flood on fishes (increased mortality and/or displacement downstream), may have been responsible for the decrease in biomass between 1990 and 1991.

In 1991, dace and sculpins were collected in all of the Middle Fork of the Teanaway River sites. These species were considered relatively abundant in the lower two sites $(0.16$ to $0.75 / \mathrm{m}^{2}$ ), while dace were less abundant in the uppermost site $\left(0.06 / \mathrm{m}^{2}\right)$

\section{NORTH FORK OF THE TEAWAWAY RIVER}

Population density of salmonids in the North Fork of the Teanaway was lower in 1991 than in 1990 (Table 4). The species (origin) composition changed in all sites in 1991 with the, introduction of hatchery-reared summer steelhead smolts for another portion of our project (see Smolt Release Study, this 
report). Juvenile spring chinook salmon abundance was lower in 1991 than in 1990 in the lower North Fork site as was seen in the West and Middle forks was also observed in the lower North Fork site (Table 4). Hatchery steelhead were much larger ( mean $=197$ $\mathrm{mm}$ ) than rainbow trout (mean $=104 \mathrm{~mm})$, and therefore accounted for a larger percentage of the total biomass than number. Bull trout constituted $11 \%$ of the salmonids present in the uppermost site in 1990 but were not observed in that site in 1991. This site was dominated by cutthroat trout during both years. In 1990, the uppermost site in the North Fork of the Teanaway River had the highest biomass $\left(4.71 \mathrm{~g} / \mathrm{m}^{2}\right)$ of any tributary site surveyed (Table 5). Mean biomass decreased between 1990 and 1991 in the upper and middle sections, while nearly doubling in the lowermost section. The introduction of hatchery steelhead may have been responsible for the increased biomass in the lower site.

Pool habitat in the North Fork of the Teanaway River sites decreased substantially between 1990 and 1991, resulting in the complete elimination of pool habitat in the lower and middle sites (Table 5). As -previously mentioned, flooding in late 1990 was responsible for much of the alteration in channel morphology. Sculpins were relatively abundant $\left(0.19\right.$ to $\left.0.57 / \mathrm{m}^{2}\right)$, during 1991, in the North Fork of the Teanaway River study sites. Dace were less plentiful $\left(0.04\right.$ to $\left.0.08 / \mathrm{m}^{2}\right)$ in this stream., 


\section{CABIX CREEK}

The lower elevation site in Cabin Creek contained an estimated 11 salmonids (six brook, two rainbow, one putative hybrid trout, and two juvenile spring chinook salmon; Table 4) in 1990. Salmonid densities $\left(* / \mathrm{m}^{2}\right)$ in Cabin Creek were some of the lowest measured in any study site, The estimated number of salmonids in 1991 in the lower section was nearly three times higher than it was the previous year. However, the biomass remained virtually unchanged (Table 4). This is explained by the decrease in the mean size of salmonids present in this site between years. For example, in 1990, the mean length of rainbow trout in this site was $91 \mathrm{~mm}$, whereas the corresponding length for 1991 was only $63 \mathrm{~mm}$. The flood impacted this basin more than others due, possibly, to its steepness and logging history. Species richness was much greater in 1990 than in 1991. Juvenile spring chinook were present in both sites in 1990 and none were detected in 1991. Brook trout dominated (55\% by number) the lower site in 1990 and comprised only $14 \%$ of the population in 1991 (Table 4). The upper site contained rainbow, cutthroat, brook, and apparent hybrid trout as well as spring chinook salmon in 1990, whereas it contained only rainbow trout in 1991.

Biomass in both Cabin Creek sites remained remarkably stable through the drastic environmental changes that took place 
between 1990 and 1991 (Table 4). Mean biomass (both sections and years pooled) was lowest of all tributaries sampled (Table 4). Physical habitat in Cabin Creek was dominated by riffles. This was especially so in 1991 when 66 and 78\% of habitat in the lower and upper sites, respectively, were classified as riffles (Table 5). The percentage of habitat made up by pools in the upper site changed from 10 to $0 \%$, probably due to the flooding in late 1990.

Other species observed in Cabin Creek in 1991 were dace and sculpins. Sculpins were abundant $\left(0.66\right.$ to $\left.1.04 / \mathrm{m}^{2}\right)$ in both sites, while dace were present only in the lower site $\left(0.14 / \mathrm{m}^{2}\right)$.

\section{Mainstem Yakima River}

Estimates of resident trout densities 'in the mainstem Yakima River were considerably lower in 1991 than in 1990 (Table 6). Densities in 1990 ranged from 413 to 765 trout $/ \mathrm{km}$ for all sections, and from 27.4 to 314 trout $/ \mathrm{km}$ in 1991. Population density in the Upper Canyon section (section 2) decreased considerably from 1990 to 1991. Population densities in the Thorp section (section 4) were most similar (but also decreased) between years. Population densities decreased in all other sections by more than half between 1990 and 1991 . The population estimate for the Cle Elum section (section 5) in 1991, was invalid due to an insufficient number of recaptures. Biomass $(\mathrm{kg} / \mathrm{km})$ 
also decreased in all sections (Table 6). The Ellensburg section showed the greatest decrease in biomass with a $74 \%$ decline between 1990 and 1991 .

Although it was not possible to determine the causes of the apparent decline in population size between years, alternative explanations are listed below.

1) Actual changes in population levels occurred due to natural processes such as severe flooding or human influences.

2) Methodological changes made between years, wherein the mobile anode system used in 1990 was replaced with the stationary boom anode (in 1991) and the number of sample release sites was increased in 1991.

3) A combination of 1 and 2 .

The occurrence of a massive (recurrence interval: 50 to 100 years) flood in November, 1990, may have substantially increased mortality rates of juvenile trout. The length frequency distributions for the Lower and Upper Canyon sections pooled, shows a decline in the percentage of trout in the 175 to $225 \mathrm{~mm}$ size class (Figure 11). Fish of this size would have been age 0 or age 1 fish during the fall of 1990 when the large flood occurred, suggesting that mortality on this segment of the population may have been substantially increased by the flood. In 1990, this size range accounted for $27 \%$ of the trout sampled, while in 1991 it was reduced to only 17\%. This reduction in 
young fish, possibly due to flooding, may account for much of the change seen in the mainstem Yakima River sections between 1990 and 1991. The mean length of trout also decreased in four of the

Table 6. Resident trout population estimates (with 95\% confidence intervals), biomass (kg/section), number per kilometer, kilogram\& per kilometer, and mean fork length in millimeters of trout (Length) for five sections of the Yakima River mainstem during the fall of 1990 and 1991 . Percent change (between years) for each section is shown in the rows marked CHANGE .

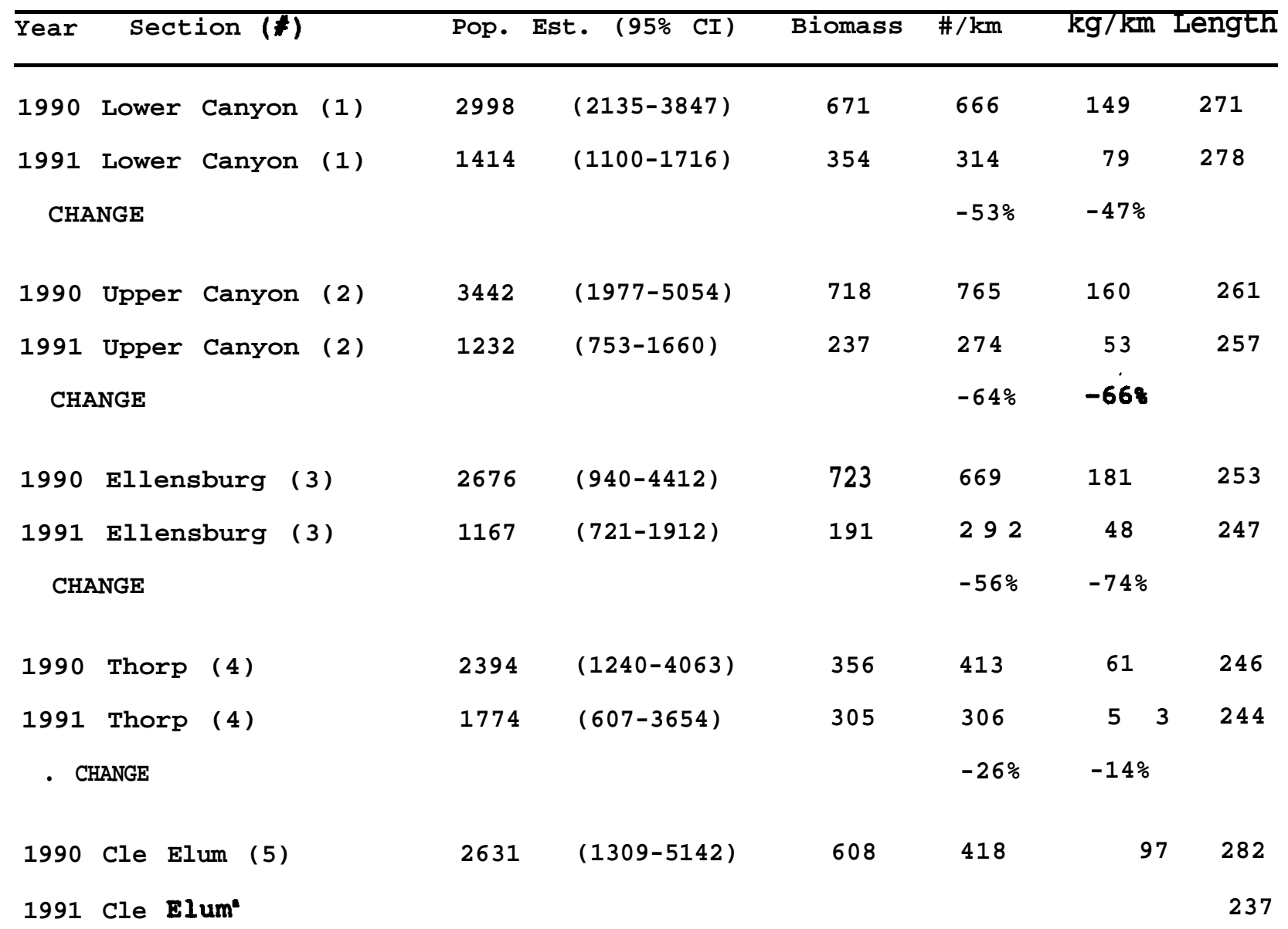

- Invalid estimate due to low collection efficiency 


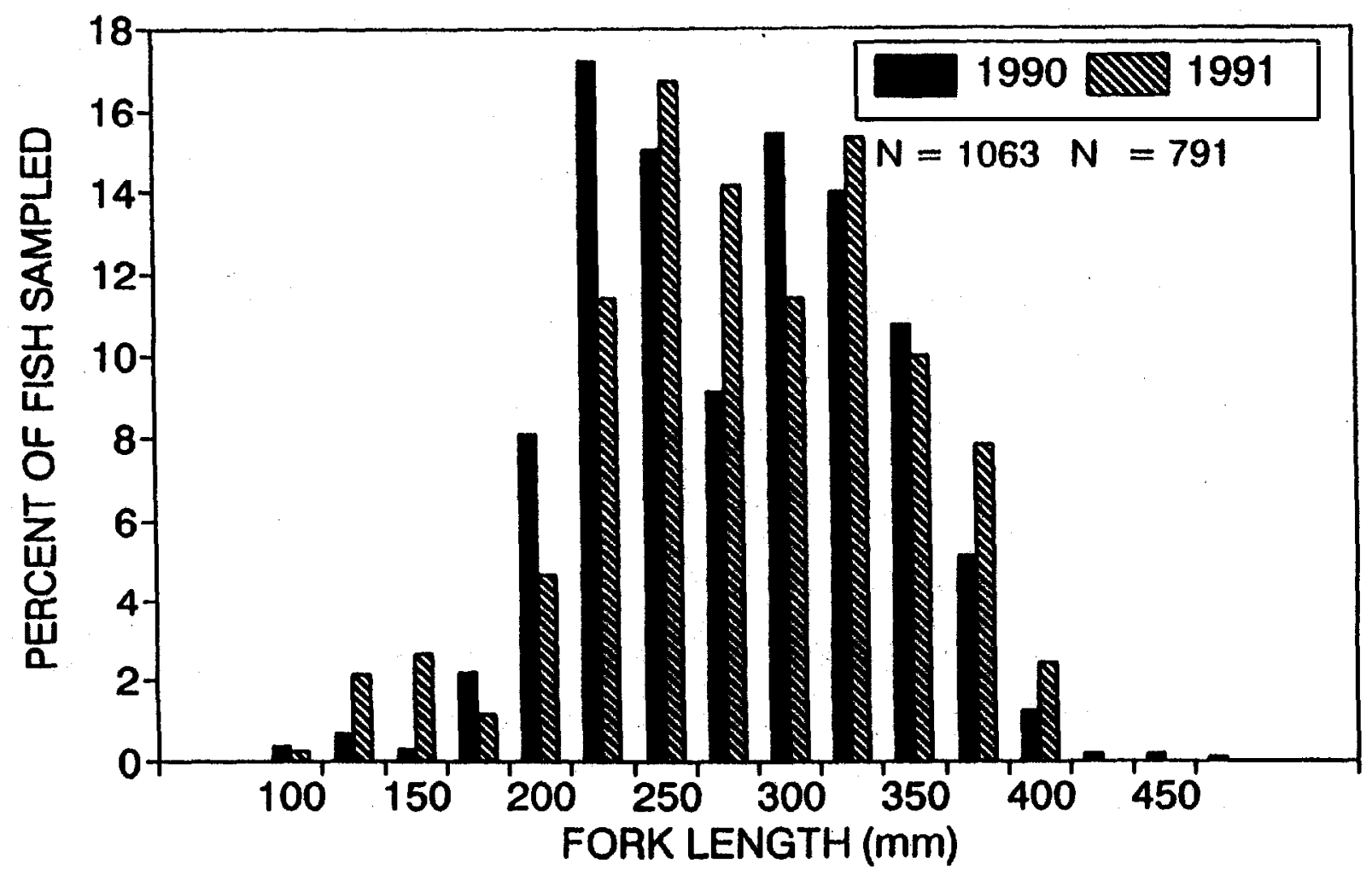

Figure 11. Length frequency distributions for mainstem Yakima River Upper and Lower Canyon sections pooled for fall of 1990 and 1991. Samples sizes (N) for each are shown.

five sections between 1990 and 1991 (Table 6). It should be pointed out, however, that we suspect the equipment's capture efficiency on the smaller size classes was greater in 1991 than in 1990. Overall capture efficiencies, in 1991, with the stationary boom system were much higher (1990 average $=7.24 \%$; 1991 average $=13.78 t)$, resulting in more precise population estimates. 
Natural variation may also explain the apparent shifts in density. Changes in recruitment of juvenile fish to the adult population, survival of all life stages of trout, emigration, and reproductive success may all influence the standing crop of fish at 'a particular time and location. Human influences such as illegal angler harvest, fish kills, or habitat destruction may also affect fish abundance.

The Nelson Siding index section was snorkeled on June 28, 1990, and on October 23, 1991. The numbers of rainbow trout over $150 \mathrm{~mm}$ were very similar between years $(1990,90 ; 1991,91)$, but the numbers of trout less than $150 \mathrm{~mm}$ were considerably different (1990, 113; 1991, 30). Differences between years may be related to the seasonal difference in sampling dates. Many juvenile spring chinook were seen in $1990(\mathrm{~N}=140)$ but none were observed during the 1991 snorkel survey. Suckers were abundant in 1990 (N = 75) but were rare in $1991(\mathrm{~N}=1)$, whereas the abundance of whitefish in 1991 had increased five-fold over the previous year $(1990, \mathrm{~N}=150 ; 1991, \mathrm{~N}=738)$. Whitefish abundance in 1991 may have been so high because of spawning aggregations.

Subsections of the Crystal Springs index section were snorkeled both in May and October of 1990 and 1991. Few fish were observed in any of these surveys. Only one rainbow trout (<200 mm) and one adult whitefish were seen in May 1990 . In October 1990, 54 age 0+ rainbow trout, 29 rainbow trout $\geq$ age 1+, four age $0+$ brook trout, 54 brook trout $\geq$ age 1, 97 age $0+$ spring 
chinook, one adult spring chinook carcass, 87 age 0+ mountain whitefish, 3 age 1+ and older mountakn whitefish, 12 speckled dace, and 12 redside shiners were observed. In May 1991, no rainbow trout were seen in a two hour snorkel survey through the section. A total of seven trout, five of which were less than $150 \mathrm{~mm}$, were observed in the subsequent October survey.

In addition to trout, mountain whitefish, suckers (largescale and bridgelip), northern squawfish, sculpins, dace, and spring chinook salmon were observed in sections 1 - 5 (Lower Canyon to Cle Elum). In 1990, a largemouth bass and a pumpkinseed were captured in the Lower Canyon section (section 1). Yellow perch were observed in the Upper Canyon section in 1990. One common carp was captured in the cle Elum section in 1990. Juvenile spring chinook salmon were generally more abundant in 1990 than in 1991.

\section{Relative Abundance Surveys}

Relative abundance surveys were conducted to obtain information on the fish community structure and distribution of fishes in tributary sites throughout the study area. Although population estimates would have been preferable, the time required to conduct population estimates was too great to sample a large number of sites. The relative abundance surveys (semiquantitative (one-pass)) provided information on the species 
composition within each site sampled. We assumed all fish species within the sites exhibited similar susceptibility to capture by electrofishing. The term 'relative' in relative abundances is used because the density, estimates produced with this technique are not actual densities. With a similar level of effort in each site, the density in one 'relative abundance site' can be compared to the density in another. Because of differences in methodology (one pass versus multiple passes), the density estimates obtained through these surveys should not be directly compared to the multiple removal population estimates. In most cases, the densities reported for the relative abundance surveys would be slightly lower than actual densities because no expansion factor was applied to the data (as it was with the multiple removal estimates).

\section{Methods}

Relative abundance surveys were conducted in five tributaries of the upper Yakima River between August 5 and October 29, 1991. Relative abundance surveys were not conducted in 1990. It was possible to collect reliable information on all species (including salmonids) in tributaries only. Due to the large numbers of non-salmonids (e.g. whitefish and suckers), it was not possible to obtain accurate relative abundance information in mainstem study sections. 
Two sections were established on Umtanum Creek because of the relatively short distance of stream available to anadromous fish. Sample sites were selected representing lower, middle, and upper reaches on each, of three tributaries (Badger, Manastash, and Swauk creeks). Only one site was established in Big Creek due to access limitations. Sample sites were each approximately $200 \mathrm{~m}$ long. Relative population abundance was estimated from fish collected during a single pass electrofishing effort (Strange et al. 1989). All fish encountered were netted and placed in holding buckets. Non-salmonids (except some sculpins) were identified to family in the field and a voucher collection was preserved in $10 \%$ formalin and later identified to species in the lab. Trout were identified to species, fork length was measured to the nearest millimeter, weights were obtained to the nearest gram, the presence of hook-scars was assessed, and fish longer than $175 \mathrm{~mm}$ were anchor-tagged prior to release.

Relative abundance of-each species was expressed as number of fish per $100 \mathrm{~m}^{2}$. The number of fish present for each species were divided by the estimate of stream surface area. The total surface area for each section was calculated by multiplying the length and mean width of each habitat type (e.g. riffle, run, pool) and then adding values for each habitat type. The total number of each species present was then divided by surface area $\left(\mathrm{m}^{2}\right)$ and multiplied by 100 to give an estimate of fish per.100 $\mathrm{m}^{2}$. 
The relative densities were then converted to a qualitative ranking using the following criteria: 0 fish/100 $\mathrm{m}^{2}=$ "none"; 0.1 - $1.3 \mathrm{fish} / 100 \mathrm{~m}^{2}=$ "few"; $1.4-3.9 \mathrm{fish} / 100 \mathrm{~m}^{2}=$ "common"; 4.0 or more fish/100 $\mathrm{m}^{2}=$ "abundant". These criteria were selected based on the typical range of densities observed in tributary index sites throughout the study area.

\section{Results and Discussion}

In general, rainbow trout and sculpins were the most common species in the tributary sites sampled (Table 7). Similar to the findings of the multiple removal tributary population estimates, species composition tended to shift toward cutthroat and brook trout in'the upper reaches of some streams (e.g. Manastash and Swauk creeks). Rainbow trout were the only trout species found in Umtanum Creek and were abundant in both sections, although much higher densities were encountered in the lower section $\left(17.9 / 100 \mathrm{~m}^{2}\right)$ than in the section above the beaver dams $(5.8 / 100$ $\mathrm{m}^{2}$; Table 8). Rainbow trout in the lower section were predominately age $0+$, with $77 \%$ of all rainbow trout sampled $(\mathrm{N}=$ 76) less than $100 \mathrm{~mm}$ in length. In contrast, only $19 \%(\mathrm{~N}=27)$ were less than $100 \mathrm{~mm}$ long in the upper section. Although flow, temperature and gradient were similar'between the two sections of Umtanum Creek, there were major differences between the 
Table 7. Relative density estimates ( $\# / 100 \mathrm{~m}^{2}$ ) for all species by section in five tributaries of the upper Yakima River during fall, 1991. Abundant (abun) $=>4.0$, common $(\operatorname{corn})=1.4-3.9$, few $=0.1-1.3$, and none $=0 \mathrm{fish} / 100 \mathrm{~m}^{2}$.

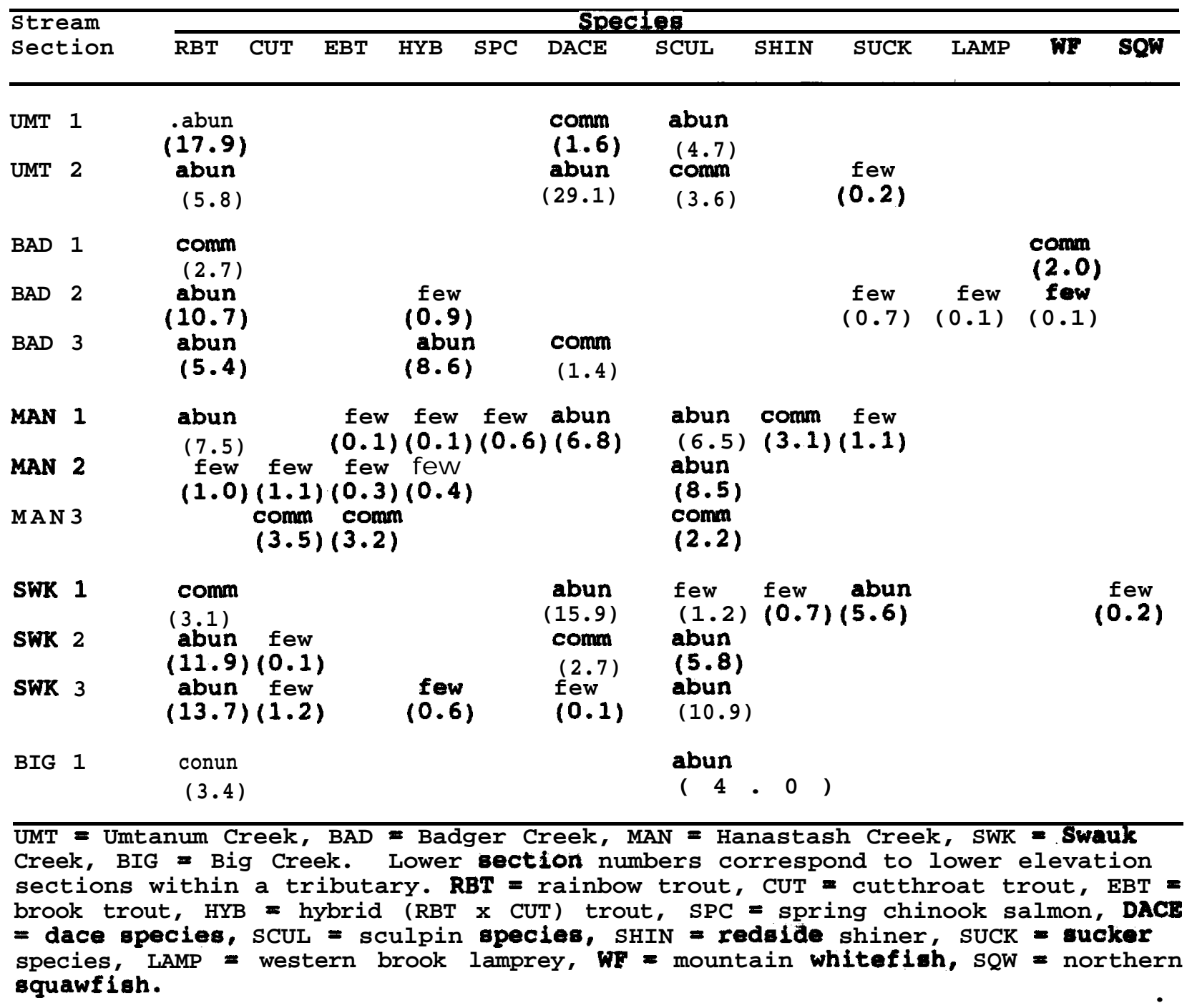

composition of habitat types in the sampled sections (Table 8). The lower section was predominately riffles (46\%) and runs (32\%), and contained mostly cobble and boulder substrate. The upper 
section had only a few riffles (13\%) and was dominated by pools (69\%) with heavily silted substrate. The lower numbers of trout and larger numbers of dace in this upper section could be related to this difference in habitat structure between sections in Umtanum Creek.

The greatest species richness in Badger Creek was in the intermediate section (Table 7). The relative density of trout in Badger Creek increased with distance upstream, although the upper section had a higher percentage of putative hybrid trout than the other two sections. The habitat in Badger Creek was similar in all three study sections, with riffles and runs being the dominant habitat types. Pool habitat was artificially increased in Badger Creek during the irrigation season by landowners installing boards on diversion dams. Land use around Badger Creek was predominately agricultural and sections of the heavily grass covered, providing what appeared to be excellent salmonid rearing habitat.

The species richness in Manastash Creek was higher than that of other tributaries sampled (Table 7). Species diversity was highest in the lowest section, and decreased progressively in an upstream direction. Rainbow trout density decreased with distance upstream and were totally absent in the uppermost section. In comparison, cutthroat trout were absent in the lowest section and increased in density upstream. Brook trout were present in all three sections and were in spawning condition 
Table 8. Physical characteristics of habitat in study sites used for relative abundance surveys in tributaries to the upper Yakima River, fall 1991. Sample date, percentage riffle, run, pool habitat, total area, flow, and water temperature are shown for each site.

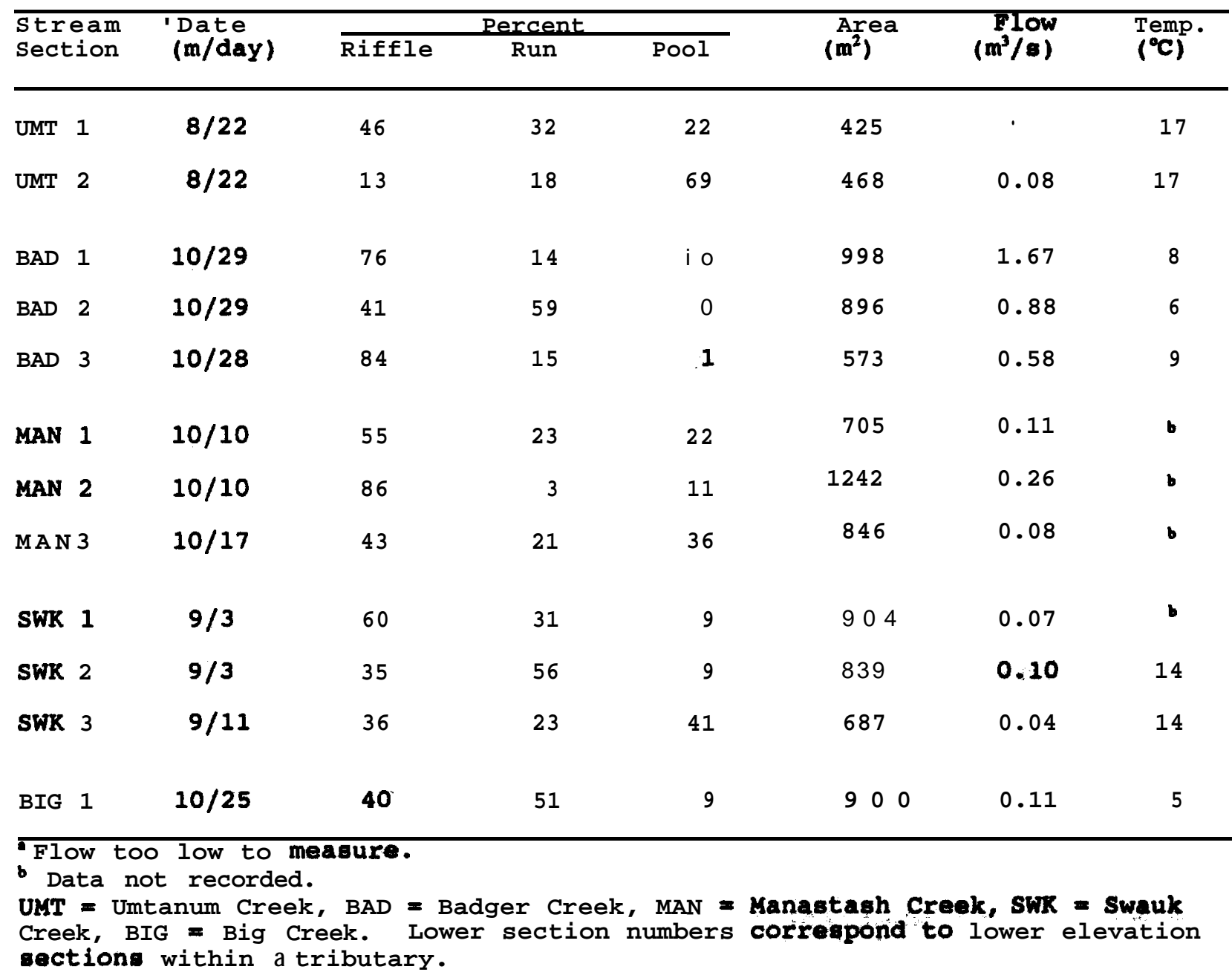

on October 17. Of the 27 brook trout sampled on that date, 21 were mature-or spent (78\%).

Study sections in Swauk Creek encompassed a wide range of habitat conditions over approximately $24 \mathrm{~km}$ of stream. The 
lowest section of Swauk Creek contained the most species and rainbow trout were common to abundant in all three sites (Table 7). The upper section contains a series of pools that were formed through habitat modification. Consequently, the largest percentage (41\%) of pool habitat was found in this section (Table 8).

The fish community in Big Creek was relatively simple with only rainbow trout and sculpin observed (Table 7). This creek had the lowest number of species observed of any tributary surveyed. The habitat in Big Creek consisted primarily of runs and riffles, with very little pool habitat available (Table 8).

\section{Rearing Survey Summary}

Tributaries

Salmonid abundance and species composition in tributary index sites were very different between 'streams and years. Taneum Creek and the Middle Fork of the Teanaway River had high mean salmonid densities (Oc.13 and 0.18 salmonids/ $\mathrm{m}^{2}$, respectively) when the years and sections were pooled. Mean biomass $\left(\mathrm{g} / \mathrm{m}^{2}\right)$ increased in Taneum Creek and the West Fork of the Teanaway River between 1990 and 1991, while it decreased in the Middle and North forks of the Teanaway River and remained remarkably stable in Cabin Creek. In general, the mean lengths of trout observed in tributary population estimate index sites 
were smaller in 1991 than they were the previous year. This decrease in larger fish may be due, in part, to the occurrence of a major flood event that occurred in the study area in November of 1990. These larger fish $(100-200 \mathrm{~mm})$ would have been age 0 fish during the fall of 1990 when the flood occurred. Juvenile spring chinook salmon were totally absent from all tributary study sections in 1991 where significant numbers (up to 55\% of the total) were found in 1990. The flood may have increased preemergence mortality of eggs which were deposited in the gravels about two months prior to the flooding. Uppermost sites in most tributaries contained higher species diversity (with respect to salmonids) than did lower sites within a tributary. Daces and sculpins were the species found most frequently in sympatry with rainbow trout.

Physical habitat in tributary sites changed between -1990 and 1991. The percentage of the total area within most sites that was pool habitat decreased between years, while runs and riffles accounted for more of the area in 1991. The flood may have been responsible for some of this channel restructuring. Kennedy and Strange (1982) found that densities of older trout highly positively correlated to area of deep water $(P<0.001)$ and accounted for the majority of trout biomass. Rainbow trout biomass in tributaries in 1991 was also strongly correlated with pool area $(\mathrm{N}=14, \mathrm{P}<0.001, \mathrm{R}=0.806)$ but poorly correlated in $1990(\mathrm{~N}=14, \mathrm{P}=0.393, \mathrm{R}=0.248)$. 


\section{Mainstem Yakima River}

Resident trout densities in the mainstem Yakima River were much lower in 1991 than in 1990. Numerical density (\#/km) and biomass $(\mathrm{kg} / \mathrm{km})$ of trout decreased an average of $50 \%$ for all sections pooled between 1990 and 1991. Changes in population levels due to severe flood and/or natural variation, human influences, as well as methodological changes in our surveys may account for the reduction in abundance of trout in the Yakima River study sections between years. A lower percentage of the trout captured during 1991 were age 0+ trout during the fall flood. This reduction suggests that the smaller length groups suffered disproportionately higher mortality rates and supports the theory that the flood was responsible for some of the reduction in abundance in 1991.

Snorkel surveys in the upper two sections of the mainstem Yakima River also revealed fewer small trout in 1991 than in 1990. Juvenile spring chinook salmon, plentiful in 1991, were not observed in either of these upper sections in 1990. The uppermost section of the Yakima River (Crystal Springs) was found to have very few fish in the fall of 1991, while a survey the previous fall showed approximately 200 salmonids.

Species diversity generally increased with distance downstream. Spring chinook salmon juveniles were less abundant in the 1991 surveys. 


\section{Relative Abundance Survevs}

Surveys intended to provide semi-quantitative fish abundance and distribution information were initiated on five tributaries during the summer of 1991. Single pass electrofishing in these tributaries was used to capture fish in lower, middle, and upper elevation sites (each approximately 200 m long) Fish numbers were divided by the area of each site to determine the relative density of the various species present in each site. Criteria for the ranking of abundance across tributaries was established based on the typical ranges of densities observed throughout the tributaries in the study area.

Rainbow trout were classified as common to abundant $(2.7$ to $17.9 / 100 \mathrm{~m}^{2}$ ) in all sites, with the exception of the middle site in Manastash Creek where they were classified as "few" (1.0/100 $\mathrm{m}^{2}$ ) and the uppermost Manastash Creek site in which rainbow trout were not observed. The lowest site in Manastash Creek had the greatest species diversity (eight species) while lower Badger Creek and Big Creek only contained two species.

\section{MOVEXPAY AND GROTHA}

By examining the data collected from individually tagged fish that are recaptured, it is possible to assess the net distance moved as well as the net growth of the fish. Large 
numbers of tags have been placed in trout within the upper Yakima River basin in the past two years $(2,721$ in $1990 ; 2,543$ in 1991). With a large number of tags placed in fish during spawning and rearing surveys, many recaptures are made that may be used to document individual fish movement and growth.

Methods

Information on movement and growth of individual tagged resident trout was available from tag numbers reported by anglers, observations at Prosser and Roza dams, and reobser/ations during routine field activities. In summarizing data on growth based on tag data, fish lengths reported by anglers were not included to ensure only consistent and reliable methods were used. In addition, unless data was included on specific location of capture, fish were excluded from the fish movementdatabase. Fish movement data was based on repeated observations from field activities of the research team. Each time a tagged fish was reobserved, locations were plotted and the distance moved (since tag insertion or last observation) was estimated using scale planimetric maps at a scale of 1:100,000 or 1:150,000, and a PECO map measurer. Fish recaptured 'in the same section where they were originally tagged were assumed to have not moved. Growth and movement data were summarized for all recaptured fish for which accurate length and capture locations were known. 
of the total of 2,721 tags placed in fish in 1990, 135 had been reobserved by the end of 1991 (51 in 1990; 84 in 1991). Seventy-eight tagged fish were reobserved during 1991 that were tagged earlier that year. For 1990 and 1991 combined, anglers provided information on 75 tagged fish (35\% of the total number reobserved). Angler participation has steadily improved as the number of tagged fish increases and anglers become -informed through public presentations or signs placed at river access locations. Juvenile passage facilities operated by YIN provided information on four tagged fish (2\% of total), while 134 (63\%) were reobserved during routine field activities of the study team.

\section{Movement}

Movement data compiled from tag information returned by anglers, reobservations at dams, and recaptures during routine field activities indicated a general lack of movement. Much of the movement observed seemed to occur between sections within a given stream or between adjacent mainstem Yakima River sections (generally less than $4 \mathrm{~km}$ ). However, limited movement was observed from tributaries in which fish were tagged (Umtanum, Badger, and Cherry creeks) in the springs of 1990 and 1991 to mainstem sections in which they were reobserved in the fall of 
the same year (Table 9). In March of 1990, three rainbow trout were tagged in Cherry Creek and were recaptured in the mainstem Yakima River later that fall. In March of 1991, four rainbow trout tagged during tributary spawning surveys (one female in Badger Creek, one male and two other rainbow trout in Umtanum Creek) were recaptured in the mainstem between May and November. This limited information suggests that some trout in the mainstem moved into the tributaries to spawn and then returned to the mainstem. However, individuals have been tagged in the mainstem during the spawning season only to be recaptured in the same mainstem study sectionduring rearing surveys in the fall, suggesting that at least part of the resident population spawned and reared entirely in the mainstem. The incidence of tagged individuals in the same tributary and study section during both spawning and rearing surveys suggests that there may also have been fish in tributaries that did not move far out of a given area. Admittedly, in some cases the timing of tagging and recapture could obscure actual movements that were not reflected in the data by the methods used in this study. 
Table 9. Summary information on tagged rainbow trout that were recaptured in tributaries and mainstem Yakima River study sections during 1990 and 1991. Stream (or mainstem section), number of fish recaptured (N), percent of fish that moved a distance of $0 \mathrm{~km}$ (Zero), $0.1-4.0 \mathrm{~km}$, and more than $4.0 \mathrm{~km}$, percent of fish that moved from tributaries (Tribs) and mainstem areas (Mainstem), mean number of days at large in 1990 (Days 90) and 1991 (Days 91), and mean growth (mm/day) of trout are shown. Pooled and mean numbers are given below the tributaries (Trib Total)., and mainstem sections (Yak Totals).

\begin{tabular}{|c|c|c|c|c|c|c|c|c|c|}
\hline $\begin{array}{l}\text { Stream/ } \\
\text { Section }\end{array}$ & $\mathbf{N}$ & $\frac{\text { Dista }}{\text { Zero }}$ & $\frac{\text { nce MOV }}{0.1-4}$ & $\frac{\mathrm{ed} 19}{>4.0}$ & $\frac{\text { Perce }}{\text { Tribe }}$ & $\frac{\text { nt From }}{\text { Mainatem }}$ & Days 90 & Days 91 & Growth \\
\hline \multicolumn{10}{|l|}{ Tributaries } \\
\hline Umtanum & 6 & 100 & 0 & 6 & 100 & 0 & & 135 & 0.02 \\
\hline Badger & 1 & 0 & 0 & 100 & 100 & 0 & & 557 & . \\
\hline Cherry & 12 & 50 & 42 & 8 & 42 & 58 & 105 & 105 & 0.07 \\
\hline Wilson & 28 & 57 & 43 & 0 & 100 & 0 & 236 & 201 & 0.16 \\
\hline Taneum & 2 & 100 & 0 & 0 & 100 & 0 & & 347 & 0.03 \\
\hline Teanaway & 14 & 86 & 14 & 0 & 100 & 0 & & 215 & 0.05 \\
\hline $\begin{array}{c}\text { Trib Total } \\
\text { Means }\end{array}$ & 63 & 66 & 16 & 18 & 90 & 10 & 197 & 190 & 0.10 \\
\hline \multicolumn{10}{|l|}{ Mainetem } \\
\hline L. Canyon & 68 & 96 & 0 & 4 & 4 & 96 & 9 & 248 & 0.13 \\
\hline U. Canyon & 32 & 88 & 3 & 9 & 6 & 94 & 139 & 166 & 0.06 \\
\hline Eburg & 7 & 71 & 0 & 29 & 29 & 71 & 205 & 191 & 0.15 \\
\hline Thorp & 14 & 64 & 0 & 36 & 0 & 100 & 140 & 290 & 0.10 \\
\hline Elum & 9 & 100 & 0 & 0 & 0 & 100 & & 193 & 0.08 \\
\hline $\begin{array}{c}\text { Yak Total } \\
\text { Mearis }\end{array}$ & 130 & 89 & 1 & 10 & 5 & 95 & 53 & 225 & 0.11 \\
\hline
\end{tabular}

- Accurate length not available for recaptured fish

- Middle and North forks pooled 


\section{Growth}

Growth data gathered from individual tagged fish was pooled for tributaries and mainstem Yakima River sections and means are summarized in Table 9. Wilson Creek fish exhibited the highest mean rate of growth $(0.16 \mathrm{~mm} / \mathrm{d})$ of any tributary or mainstem section examined. Growth rates as high as $0.46 \mathrm{~mm} / \mathrm{d}$ were recorded for Wilson Creek trout. Trout in other tributaries generally displayed lower rates of growth. Wilson Creek appeared to have high densities of freshwater shrimp in and around submerged macrophytes. The abundance of these amphipods may help explain the phenomenal growth rates seen in this creek. Trout in the majority of tributaries grew less than a third as fast as fish in Wilson Creek. However, one brook trout was recaptured in Cabin Creek that grew at a rate of $0.48 \mathrm{~mm} / \mathrm{d}$.

Resident trout in the mainstem Yakima River grew an average of $0.11 \mathrm{~mm} / \mathrm{d}$, which is a slightly higher rate than the mean growth rate of trout in the tributaries (Table 9). Within the mainstem Yakima River, the highest rate of growth was observed in the Ellensburg section $(0.15 \mathrm{~mm} / \mathrm{d})$. However, the mean length of trout in this section was relatively small in comparison to other sections (Table 6) which may partially explain why trout there grew faster than trout in 'other areas of the mainstem. The highest growth rate for individual trout in the mainstem was 0.50 $\mathrm{mm} / \mathrm{d}$ from a trout recaptured in the Lower Canyon section. 
Because 'our sampling methods include the use of . As the electrofishing, caution should be used in referring to these growth rates as characteristic of fish that were not exposed to electrofishing (unexposed fish may grow faster)(Gatz et $\mathbf{a}$. 1986'): The data are useful, however; in comparing relative: growth rates between streams and se\&ions of the mainstem, as the collection methods were similar in most circumstances.

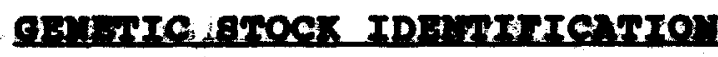

Genetic. investigations of-:. resident trout populations above Roza Dam have multiple objectives.. These are to: (1) determine population genetic strueture, (2) assess the extent of hatchery vs. wild ancestry, and (3) assess tools to discriminate sympatric resident trout from juvenile steelhead troutut In addition, collection of genetic data will also allow an assaesment of the extent of hybridization between the rainbow/steel habd complows and cutthroat trout. Genetio sampling has been conductad inee the spring of 1990 (Hindman et ald 1991) . Electrophomatic and statistical analyses of genetic dattwene prepidad to wom nuta subcontract with the wDF Genetics Unitry whose reporti is insinded in this progress report as Appendix A: a Thericurrent report covers sampling and analyses from the spring of 1990 through the spring of 1991. Results from work accompliahed after that time will be 
presented in. a future progress report. It is important to note that all results should be considered preliminary, unt 11 final genetic analyses are completed. .

As described in Hindman et al. (1991); for sampling purposes, tributariee in the study area were divided into preestablished areas or clusters according to geographic proximity and similarities in stream morphology, ,elevation and gradient. Target sample sizes in tributaries were approximately $100 \mathrm{fish}$ per cluster. The mainstem of the Yakima River was divided into seven reaches based on criteria similar to those applied to tributaries. A total of 25 fish were targeted for collection from each mainstem reach." Sample treatment in the $f$ iald .and laboratory was as described by Hindman et a1: (1991) and Appendix A. Sample processing, protocoly and statittical analysis 1 ratso described in Appendix A.

Results of the initial analysis suggested that considecable genetic variation exists within the sampled area (Appendix A) . sampled resident trout tended to be included in one of threat: general population clusterst (1) Yakima Aiver mainstem foctions 2-7) and tributaries below. Ellensburg Dam, (2) upper Yakima tributaries and upper mains\&\&n- (section 1), and (3) tribataries between Ellensbarg Dam and Cle Elan, inoluding the Teanaway diver complex. Fish in the latter group appear to be falmly distinct from fish in the mainstem Yakima River. There appears to hame: been relatively little contribution from hatchery ralnbot trout 
in sampled populatione.: In gonerd, evidence of hatchery ancestry was greatest in the cluster comprised of lower tributaries and mainstem areas (eluster 1), and least in tributaries between Ellensburg Dam and Cle Elum (cluster B). The results of genetic sampling and analyess to date provide much information useful in characterizing the biologioal attributes and status of resident trout in the upper Yakima River, and should, contribute towarda development of a exid baseline for long term monitoring of genetic changes once the YFP is implemented. Additional sampling was accomplished in the fall of 1991 and during 1992. Incorporation of additional information should greatly enhance and refine the interptetation of datar presented herein, especially Wit\& respect to the temporal on stability ofpreliminary patterns of genetic structure identified. Additional data; coupled with consistent attainment of sampling target levele will also allew the extent of wituryear variability to be evaluated.

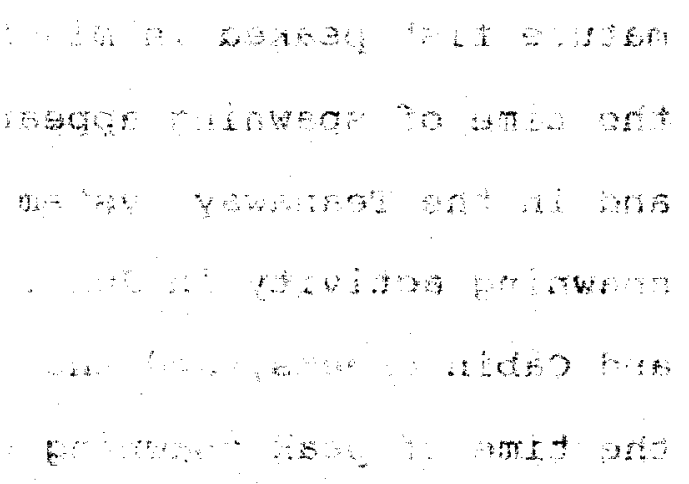


Results from tributary electrofishing surveys indlcated that a greater number of larger and older resident troat were-present in the lower elevation tributaries than were present in the upper elevation tributaries.- Trout collected in Cherry, Milson, and Badger creeks ranged in length from-79 to $465 \mathrm{~mm}$. wilson Creek contained fish of the largest mean length $(309 \mathrm{~mm})$ of any . tributary or mainstem section in the study area, as well as the highest individual fish fecundity counts of all areas sampled. Upper elevation tributaries (Taneum, Swauk, the Teanaway grtem, and Big Creek) contained very few trout greater than $200 \mathrm{~mm}$, with the majority averaging less than $150 \mathrm{~mm} . .$.

Based on the information collected from the 1991 spawning. surveys, we estimated that peak spawning activity in untanum.. Creek occurred from mid-March to the beginning of Apwil. Fortc Badger, Cherry, and Wilson creeks, the percentage of sexually mature fish peaked in mid-April. For Manastash and Swauk creeks, the time of spawning appeared to peak in late April to early May, and in the Teanaway system all three forks showed a peak in spawning activity in June. Too few trout were collected in Big and Cabin creeks, and the Cle Elum River for us to speculate on the time of peak spawning there. As distance upstream increases through the study area, spawning activity appears to be slightly delayed. Colder water temperatures, later into the spring, are 
most likely responsible for the delayed spawning activity.

The percentage of sexually mature trout in each tributan. study section indicated here rainbow trout spawning occurred within each tributary. With the exception of upper Cherry Creek (poor spawning habitat available), most areas sampled con\&! \&Mad sexually mature trout. Other exceptions include the uppermont section of Taneum Creak and-the uppermost section of the Weat Fork of the Teanaway River, both of which ware limited by amall sample sizes.

The presence of fish with hooking Injuries indicated that fish may spend 'at least part of their life cycle in the mainatem of the Yakima River whore angling pressure is greatest, and we some tributarfes for pawning purposes. The highest percentage of hook-scarred fish (23\%) in a tributary occurred in the lower section of wilsion creak, while some evidence af previous capture by anglers was also noted in tratanum, Cherry, Badger, and nenoum "\&reeks; No fish with hook-scars were captured in Manastaeh ; Swauk, the Teanaway syetem, or Big and cabin creaks.?

Averages condition tactor in the spring of the yearetor upper Yakima River basin rainbow trout appeared to be low on enly one tributary (Swauk Creek) reached the standard for rainbos: trout (mean $=1.12$ ) reported by Carlander (1969).

Fecundity was deternined for all mature female trout obept for genet lo analyste. The mean number of oggs per tish ranged from' 342 (mean FL $=182 \mathrm{~mm}$, Taneum Creak) to 2,151 (mean $\mathrm{FL}=386$ 
$\mathrm{mm}$, wilson Creek). Fish length explained $62 \%$ of the variation in number of eggs while fish weight explained $90 \%$.

Sexual maturity of fish in the Lower canyon section (section 1) peaked in February' (268) while fish in the Upper Canyon (section 2) and Ellensburg (section 3) sections: had the highest percentage of sexually mature fish in March. Trout in the Thorp area (section 4) peaked in sexual maturity during April surveys and fish in the Cle Elum section (section 5) appeared to peak in February $(17 \%)$. However, high water conditions inhibited effective electrofishing success during March and April. This pattern is similar to the tributary results (i.e. as distanqe, upstream increases, spawning activity appeared to peak later) ). A total of 736 rainbow trout wer captured during spawning surveys on the mainstem Yakima River with 6 mean length of $273 \mathrm{~mm}$ (range 73-498 mm). Scale analysis 'has not yet been complated on trout from the mainstem of the Yakima River but the lengthe :. frequencies appear to indicate-that there were three strong year classes of rainbow trout (age $1+, 2+$, and $3+$ ) with twajweak year classes- $(4+$ and 5+). The largest rainbow trout captured, as well as the largest mean size on mainstem surveys was in the Nelson Siding section (section 6 ) :.

Hook-scarred fish were evident in all sections, with the exception of 6 and 7, (small sample sizes), and the highest incidence was in sections 1 and 2 (27\%). The pereentage of sexually mature trout was-similar (range $10 \%-24 \%$ ) in all,, 
sections indicating spawning oceurred throughout the maineten of the Yakima River. The average condition factor for all ections pooled was- low (0.77) -and generally increased in the higher (upstream) areas.

The National Marine Fisheries Service (NiFs) concurrently conducted radiotelemetry studies to define the spatial and temporal distribution of steelhead spawning throughout the Yokima River basin. This research, coupled with our spawning surveys, will he\&p identify the temporal and spatial overlap between spawning steelhead and resident trout. Once the spawning axans are identified it will be possible to more accurately estimate the probability of interactions.

Population estimates in the tributaries showed a wide range of densities and species distributions between 1990 and 1991 . Abundance of rainbow trout was higher in lowen stes (thoes closer to the mouth) while cutthroat trout were wore abundant in upstream areas. A flood in late 1990 may expladn the overald absence of juvenile epring chinook in the foll 1992 antimateptas well as the decreased numbers of brook trout fanother filah that

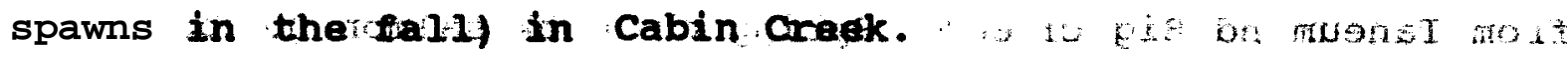

Habitat in tributary sites Was altered betreen 1990 and $c$ 1991, presumably by the flood, with the percentage of pools present being less in 1991. The effects of the logd an the habitat and fish community were most evident in Cabin creak, where the steepness of the terrain as weil asthe bain's logging 


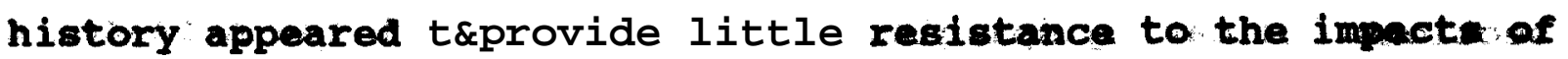
flooding.

Mainstem Yakima River trout population estimates were considerably lower in the fall of 1991 than they were year earlier. A large flood event, as well as equipment and methods modif ications between years, may have influenced estimated population sizes. Sinilar to the trend observed in tributaries, juvenile spring chinook salmon were also less abundant in the Yakima River study sections in 1991 than they were the previous year.

Relative abundance surveys provided semi-quantitative data of the distribution and relative density of all species of fish present in sections of five tributaries. Rainbow trout were found' in all but one tributary study 'site fuppermost: Manastash Creek). The-greatest species diversity was obsierved in the lower Manastash Creek site (eight species). Sculpins ware the most ubiquitous non-salmonid species found, and oocurred in all streams sampled with the exception of Badger Cresekt Dace wam also common in moist tgtreatu sampled although they were absent: from Taneum and Big creeks. Spring chinook salotom mubers appeared muok lower in 1991 than in 1990 rearing survey (presumably due to the November 1990 flood) and were present only in the lower study section In Manastash Creek. Other peckes present included redside shiners , suckers-, lamprey, whitefish, ! northern squawish, and hatchery steelhead (in 1981 only, 
originating from oux experimental releappe in the North Fork of the Teanaway River drainage).

Data on movement of tagged rainbow trout suggested there was little seasonal or annual movement within the study area. Some movement, however, was documented between lower elevation tributaries and the mainstem Yakima River. Information on relative rainbow trout growth (from tagged individuals) showed high growth rates in Wilson Creek and portions of the Yakima River mainstem.

Considerable genetic variation exists within the trout populations sampled. Three general population, clusters were identified in the Yakima basin above Roza Dam.

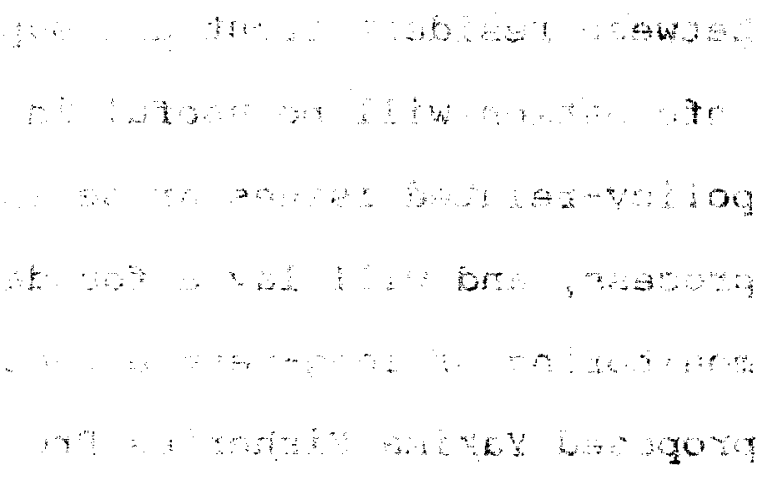




\section{EXPERIMENTATION PHASE}

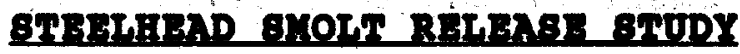

\section{Introduction}

'Research on species interactions was initiated primarily to investigate the question of what impacts, if any, supplementation with artificially-produced spring chinook salmon and steelhead trout would have on pre-existing resident trout in the 'upper Yakima River basin. Current research activities are diverse, including baseline assessments of trout spawning and rearing' distribution, abundance, growth, and genetic characteristics (see Baseline Phase, this report). In coordination with these baseline work efforts, the Washington Department of Wildlife initiated specific experiments to examine potential interactions between resident trout and supplemented salmonids in 1990. This information will be useful in the short term as management and policy-related issues arise in the ongoing decision-making process, and will lay a foundation for future planning and monitoring of long-term effects following implementation of the proposed Yakima Fisheries Project.

Research planning has identified two discrete stages of potential investigation of species interactions. The first phase 
includes an assesswent of the difect effects of intereotions: between released (watchery) floh and pre-axisting naturally produced fish. These effects may be manifested by factare soch as direct competition for food abi space, genetic introgresaion, and/or predation; The second phade requires an evaluation of interactions between naturally produced offspring of returning! adult hatchery flsh and pre-exieting natarally produced the The first phase c\&n b8 addressed th the short-term (i.e. 5 years) by examining the effects of test releases of hatchery smolts. In contrast, evaluation of the :-effects of phase two interactions will require more elaborate and longer term experimentil designs. Investigation of both levels of interactfons experimentation is warranted and has been Identified in the 1990 YFP Prestaclity Working Plan (PFWP). The studies described in this report are primarily related to the first phase of interactions I investigation.

To examine the effects of hatchery steelhead smolts on resident trout we- releabed 33,000 hatchery-reared Steelhead in a tributary of the upper yakima Rtver. The experimental releases were designed to be consistent with planned volitional releases from YFP acclimation facilities as described in the YFP Predesign Report (PDR- 1990).. Selection of the study stream and sample sites therein! utilized available information on proposed 5010 acclimation sites to maximize the potential, imnediate, and future contribution'to YFP planning and monitoring onee YER 
facilities are operational. Although experimentation currently focuses on interactions between resident trout and hatchery steelhead trout, it also encompasses naturally produced spxing chinook salmon. We have emphasized interactions batween resident trout and steelhead because the greatest likelihood fur interactions is anticipated to occur between ateelhead and resident trout. Resident rainbow trout and steelhead are most likely to interact because they are the same species and share many early life history requirements. Hatahery steelhead molt releases are designed to be replicated over -a total of four years, with the final smolt release occurring in 1994, and final data collection in 1995 :

'The primary objectives of the aurrent experimental design are to:

1. Determine how releases of hatchery steelhead smolts pay impact resident trout in a treatment stream.

a. Assess the occurrence of residualism by batchery steelhead and investigate 1ts influence on resident trout.

This report covers only the first year of multi-year study, and the data presented herein should be constdered : : preliminary. It Should be emphasized that: hatchery fish produced by the YFP are expected to be more similar to wild fish than 
traditional hatchery products. Yakima Fisheries Project fiah will be produced using innovative broodstock selection, mating. and rearing strategies. Obvtously, since profuction of these fish has not yetbegun, it was necessary to use surrogate hatchery product for the present investigations (i.e:... traditionally reared fish from the Yakima Hatohery). These hatchery fish were assumed to be of lower overall quality than: those to be produced by the YFP facilities. With respect to the behavior of Individual fish (e.g. expression of competitive tendencies), the extent to which test fish used in these studies would represent eventual YFP production is unknown. However, the fish used in this study may provide a point of reference upon which to make reasonable inferences: abont the typt and axtent of potential interactions after implenentation of the YFR. bsInsiae addition, this work provides a valuable opportunity to developu and assess Iong-termmontoring approaches. This study does not presume that salmonided in the studyon area are at carrydng capacity. Moreover; it is unikelyuthat many (if any) anadrotous salmonid stocks in the uppert Yakdmas River basin are current\&y at or near carrying capacityoniotieoxt relationship of existing residentitront popalationsfto carrying capacity is also yet unclear. Natural f isb populations at orof near carrying capacity would be expected to be the nost sensitive to influences. from any type of bioticeperturbation such as hatchery releases. However, it is not necessary that populations 
exist at carrying capacity ta investigate species interactions during a phase in which anadromous fish populations are naturally rebuilding (i.e. due to recently completed passage improvements). Such a situation reflects the current status of anadromous fish populations in the upper Yakima River watershed. .

In an integrated, cooperative relationship with this study, Central Washington University (CWU) examined food availability., and utilization of resident trout and hatchery steelhead within the study area. Preliminary findings from. their study will be: summarized in this report.

Study Area.

The North Fork of the Teanaway River (NFT)(Figure 1) was selected as the primary treatment stream for'smolt releases. 10 because acclimation facilities (where hatchery fish will be. reared for a time prior to volitional release as smolts), were proposed to be built there, and, it had a population-of naturally reproducing resident trout. Resident trout in the NFT were. predominantly rainbow trout, with some cutthroat and very few brook and bull trout (in the immediate study area). The principal study location in the treatment area included-the, lowest $2.0 \mathrm{~km}$ of -Jungle Creek (a tributary to the NFT) and the lower $11.7 \mathrm{~km}$ of the NFT. The North Fork is approximately 29.4 $\mathrm{km}$ long and drains an area of $245.5 \mathrm{~km}^{2}$. The Jungle creek 
drainage is much smaller $\left(16.0 \mathrm{~km}^{2}\right)$ and the total length $(5.0 \mathrm{~km})$ of the stream is also considerably less than thmthat the MPdet streamside vegetation in the study area was composed of conifers and deciduous trees and shrubs i subsitrate compositoton itstepe wir is dominated by cobbles and areas of exposed bedrode: substrate in Jungle Creek is primarlily rarge gravel with loome areacef exposed bedrook. A flood In Hovember of 1990 altered the 50 . geomorphology of the North Fork through gravel scowring and redeposit\&on. Thé physteal effects of theglood on Jungre creek were less noticeable. Other fish species present in the istudys area included mountalin whitef 1 sh, bridgelip aucker, langeseale sucker, longnose daca, mottredrsculpin, torient sculpin; pping chinook salmon (rare), and summer steelhead (rare).

Most of the field work for this stady was conductads in the North Fork basin, however, datà were corlected thooughout tha entire Yakima River basin while other research sativitiegeres being performed. Biological information was collected on all hatchery steelhead encountered. The number sof hatchery steeligad that were emigrating werestedhated at the month of the worth

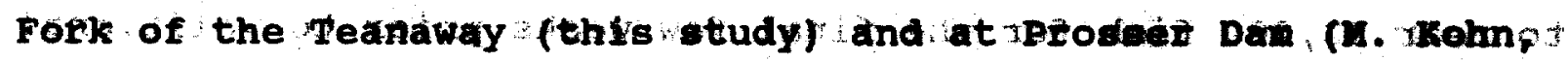

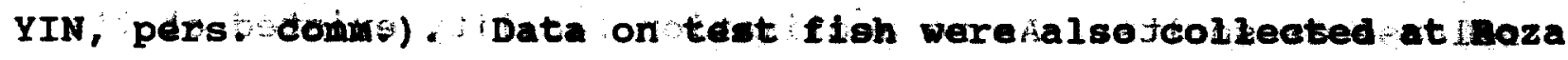

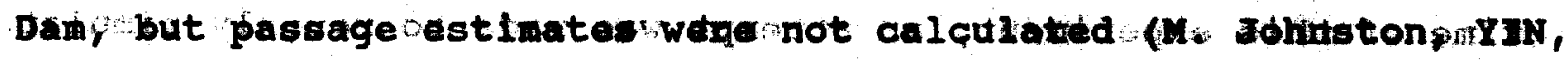
pers: comm.). 


\section{rothoda}

\section{Test Fish production}

Test fish were offspring from wild summer steelhead adulta trapped at Prosser Dam during the late fall of 1989 and early spring of 1990. Broodstock were transported to the NDW Yakima Hatchery for holding until spawing in early to late spring of 1990. Incubation and early rearing occurred at the Yakima Hatchery using standard WDW protocol. Approximately 60,000 presmolts were transported to the WDW Nelson Springs raceway in early 199.1. An attempt was made to grade, separate and freezebrand different size-classes of presmolts for experimental purposes, but facility limitations prohibited complete lsolation of different experimental groups within the raceway, At the time of release, smolts ranged-from 22.9 per $\mathrm{kg}(10.0$ per $1 \mathrm{~b}$.$) to 12.8$ per $\mathrm{kg}(5.8$ per $1 \mathrm{~b}, \mathrm{l}):$. The majority of the fish released (83t) averaged 12.8 per $\mathrm{kg}$. :

Experimental Releases:

Acclimation facilities for the yFp ore currentiy projected to rear 33,000 fish for the final faw veeks prior to yolitignal release as smolts. As no acclimation facility exhebed athe time of this experiment, an attempt was made to aroughiy abmulate the outmigration pattern that might be expected from auch facility by releasing three groups of hatchery steelhead smolts over a period of ten days, into a pool in Jungle Creek 
approximately. $0.5 \mathrm{~km}$ :-above the mouth. This ite was adjacent to a proposed acclimation facility site; ; on May 6,. 1991, 15,022 $(12.8 / \mathrm{kg})$ fish were released, followed by $11,020(12.8 / \mathrm{kg})$ on May 8 and $5,500(22.0 / \mathrm{kg})$ on Way 15 . Sexual maturity, and length and weight information was collected from a subsample $(N=50)$ of each of the three release groups. Condition factor was calculated using the following equation (Piper at al. 1983): ,

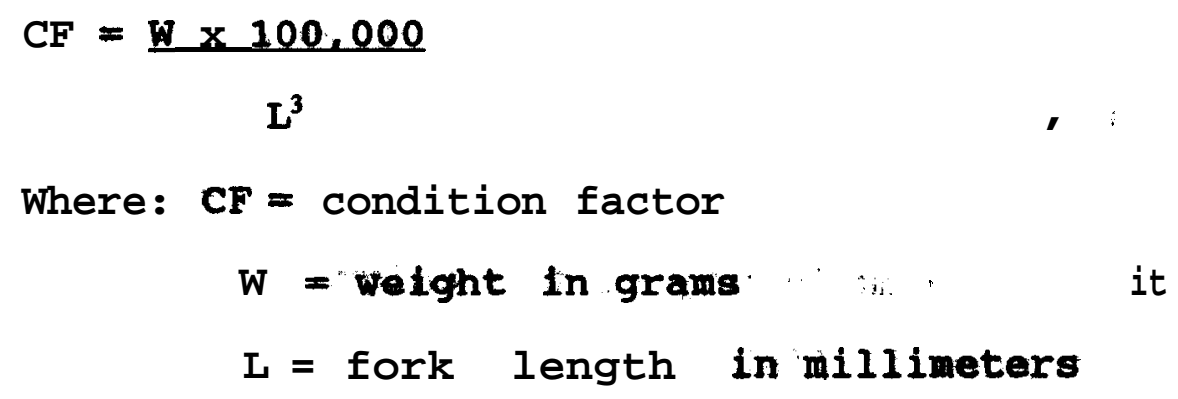

Downstream Migrant Tiapping

Traversing Fytse not.

To quantify the number of hatchery steelhead and resident trout emigrating from the treatment stream, a traversing fykeqnet was operated daily from April 22 to Nay 31 at a site $11.0 \mathrm{~km} \mathrm{~s}_{i}$, below the mouth of Jungle Creek and $0.7 \mathrm{~km}$ above the confluence of the North Fork with the mainstem Teanaway River. The Iyke net was placed in the river using hydraulic winches and positioning cables which spanned the river (Chilcote et al. 1980). The net 
(graduated mesh from $12.7 \mathrm{~mm}$ near opening to $6.35 \mathrm{~mm}$ at cod end) had a $1.8 \mathrm{~m} \times 1.8 \mathrm{~m}$ opening suspended by a frame of $25 \mathrm{~mm}$ eteel. pipe, which had a diving plane mounted on its lower edge (for more information on the concept of a traversing fyke system see Tyler 1979 and Davis et al. 1980): The net was positioned in the thalweg in an area where the stream width was approximately 10 to $12 \mathrm{~m}$. The average depth at the position of the net was approximately $1.0 \mathrm{~m}$ and the diving plane was in contact with the substrate at all times. Sampling occurred from April 22 to 29, 24 h/day. From April 30 to May 5, sampling was conducted only during hours of darkness (18:00 to 08:00 PDT), after it had been determined that the vast majority of the emigrants were captured at night. We do not know if fish moved during the daylight but avoided the net because it was visible, or if fish movement simply occurred primarily at night. From May 6 through May 12, sampling occurred $24 \mathrm{~h} /$ day, and it was confirmed that most fish continued to be captured during low light conditions for the remainder of theperiod (May-13 through May 31), the trap was operated only at night. Enumerating captured fiah and cleaning the trap of debris consumed about 10 to 30 minute8 each time the trap was checked. This cleaning of the trap accounted for about 2 hours of each sampling day that was not flehed. Most $f$ ish captured in the trap were impinged againet tha downstream end of the net by the currentand mortality rates were high. Attempts were made to minimize mortality of wild fish by 
checking the net frequently and by placing captured tish in the water immediately upon removal from the net. : All of the wild steelhead smolts that did not survive trapping ware placed on dry ice and preserved for genetic stock identification. Salmentds were identified by species and hatchery. or wild ortgin, weighed, measured, tagged ( $\mathrm{fish}>120 \mathrm{~mm}$ ), and surviving wild, -fish were released. Naturally produced steelhead smolts were distinguiehed from wild resident trout based on external physical characteristics such as overall silvery appearance, lack of parx marks, dark banding on the posterior margin of the caudal fin, and a slender body shape.

\section{Jungle Creek Trap}

We operated a small downstream migrant. trap at the wouth of Jungle Creek from May.29 through June 13 to deterwine the rate and timing of emigration of resident and test fish frem: the release stream. Trapping on Jungle creek begen two waks after the final release of hatchery steelhead to allow the najeritu of them to emigrate unimpeded. The number of fish emigrating , : directly after the smolt release was too high to tenumerate. The trap was of similar design to that used to trap adult rainbow. trout in Untanum Creek (seo Baseline Phase, thiejrepont) This trap was checked daily and all fish were enumerated, wokghed, measured and tagged ( $\mathrm{fish}>120 \mathrm{~mm}$ ). 


\section{Rosa Dan}

A permanent downstream migrant trap at the fish bypass at. Roza Dam was used to assess movement timing of hatchery steelhead released in Jungle Creek. Data on fork length, weight, and. date of capture of test fish were collected daily from May 4 to June 14 (M. Johnston, YIN, pers. comm.) . Roza Dam is located $-12.9 \mathrm{~km}$ downstream from the mouth of Jungle Creek. Estimates of the total number of test fish emigrating past Roza Dam were not available because capture efficiencies for this facility were. undetermined.

\section{Chandler Canal (Prosser Dam)}

A permanent downstream migrant trap, operated on a ... diversion canal at Prosser Dam (Chandler Canal) was used to investigate movement and survival of stealhead released into Jungle Creek. The Chandler trap is located $242 \mathrm{~km}$ downstream of Jungle Creek. With one exception, the collection of data test fish was Identical to that described above for Rosa Dan (K. Kohn, YIN, pers. comm.). In contrast to th8 data available from activities at Roza Dam, it was possible to estimate the total number of test fish emigrating past Prosser Dan, because entrainment rates and associated capture efficiencies had been determined (H. Kohn, YIN, pers. comm.). 
Fyke Not calibration Releneedst

We determined the capture efficiency of the fyke net by releasing known numbers of marked hatohery steelhead upstream of the net. Releases were made from April 22 through May 1, and. again on May 20,1991. Each often groups of hatchery steelhadd smolts were differentially marked and released on tha rigut bank of the North Fork of the Teanaway River, approximately $1.1 \mathrm{kn}$ upstream of the trappingilocation. Important assumptiona $x, y$ associated with determination of trapping efficiencies in thte case were that: (1) all marked floh migrated past the trap (e.g. none remained in the release area or were renoved by predators): (2) all-released fish had an equal; chance of being captured, and (3) trapping protocol for feflowey teste was the same -as that of routline sampling. To assess the validity of the firat assumption, snorkel surveys were conquoted in tha area between the site of fish release and the location of the fyke net. Capture efficiency of a given group was defined-ag the number of marked fioh recaptured divided by the number of market fish released.' Flow data was not avaltable: forthis meport, but ita effects on capture efflolency will be axtmined in future peports.

\section{Rearing Area surveys}

Information on the abundance and diatribution of resident trout and released steelhead was obtained bevore and aftersthe outmigration period by conducting population estlinates. 
Numerical fish density and biomass were determined in $100 \mathrm{~m}$ index sections of the North Fork of.the Teanaway River and Jungle Creek. Multiple removal population estimates (Zippin 1958) were calculated in two sections-of the North Fork of the Teanaway River in the fall of 1990 (section 1 on $10 / 8 / 90$ and section 2 on $10 / 2 / 90)$ and in the same sections in the fall of $1991 \times(9 / 9 / 91$ and 10/4/91, respectively),. The North Fork sites used in this portion of the study are the same as thoe cored to in the Baseline Phase of this report. Population estimates in the lower $100 \mathrm{~m}$ of Jungle Creek were conducted an March 8, 1991 and again on September 5, 1991. Densities of both resident trout and hatchery steelhead were also determined during underwater sampling activities (see next section). Some hatchery ateelhead were captured in other areas of the upper Yakima basin by. NDW:, while conducting baseline data collection.

\section{Underwater Observations}

Snorkeling techniques were used to obtain information on behavioral interactions-in Jungle Creek and the North Fork of the Teanaway River. In addition to recording behavioral information, the number of fish present by species and origin (hatchery or wild) was visually estimated in pre-established index sites. Three index sites were located in Jungle creak and nine index sites were in the North Fork of the Teanaway River. In, Jungle Creek, sites $1 \mathrm{~A}$ and $1 \mathrm{~B}$ were approximately $250 \mathrm{~m}$ and $200 \mathrm{~m}$, 
respectively, above the release site, whereas ite 2 was loated about 80 m below the release site. In the Worth Fork of the Teanaway sites were located $200 \mathrm{~m}$ and $60 \mathrm{~m}$ upstrean from the , mouth of Jungle Creek (sites $3 \mathrm{~A}$ and 3B, respectively). The remaining-seven isites in the North Fork of the Toanaway (sitea, $4 A, 4 B, 5 A, 5 B, 6 A, 6 B$, and 7) were located from 100 to 909 below the mouth of Jungle Creek. We chose index aites based on location, habitat atructure and presence of resident fish $\psi$ in additional constraint was that the habitat had to be accessible to snorkelers withoutdisturbing fish. Index sites uged for underwater observation-of fish ranged from one to five meter in length.

Underwater observations were conducted prior to ralease of test fish into Jungle Creek: The duration of these obseryations were 38 minutes in site $4 \mathrm{~A}$ in the North Fovk of the Teanaway River (May" 2), : and 41 minutes in site 1B (Jungle Crenk) and $13_{\circ}$ minutes-in site 2 (Jungle Creek) on May 6. A total of one to seven snorkelers (one per site) spentefive to 45 minutes observing fish at each index site on most sample dates: Ne could distinguish hatchery gteelhead from wild fish becauseothey had clipped adipese fiqs' and the fins were exoded (particulenly sio dorsal and caudal fins). Fish for which spectencand ortgin sould not be deterained (resident trout or hatchery steelbeal wore omitted from data summarization and analyses some portion of, the juvenile widd Bish identified. as resident trout may have been 
juvenile wild steelhead. Natural production of wild steelhead is known to occur in the North Fork of the Teanaway. River, although population sizes are not large.

We made behavioral observations, by snorkeling. index sitas and recording the number and type of behaviors between saimonids. We entered the water several meters downstream of the lower boundary of the index site and slowly moved upstream. When individual fish were observed, the total numbert species, and size of each fish were recorded. Snorkelers also recorded the time and number of minutes spent observing at each site: Behaviors in predeffned categories were enumerated and transferred to standard data slates. Behavior categories that were, recorded included: agonistic (aggressive) displays and attacks, physical displacement, rolding, feeding, and a fright: response thought to have been incited by the presence of the : observer (Abbott and Dill 1985; Taylor and Larkin 1986). Hierarchical (dominant vs.subordinate) relationships were also recorded.: 'Notes were reoorded at periodic intervals, which ranged from one to fifteen minutes depending on the length of-the observation period and the number and complexity of the behaviors observed. Notes were. also taken to describe, in general terns, the relative positions of fish in the water column, and their associations with features of the available habitat.: shorkeling was conducted during hours of daylight and darkness. We. attempted to observe fish during periods of darkness using 
underwater lights fitted with and without red filters. iat suse appeared that both types of lights interfered with the norul behavior of fish causing them to exhibit a fright response; and thus all further snorkeling was conducted during daylight hours.

\section{Creel Survey}

To collect information on the number of hatchery steelhead smolts and -resident trout that were harvested by anglers in the immediate study area, we conducted limited areel survey duning the first two weeks of June, 19e1. Trout fishing season began on June 1 and--continued through october. sport fishing pegulations in the Teanaway system allowed anglers to kill eight trout of any size per day, and there were no special restrictions regarding use of bait. Creel surveyors performed on-site angler interviews and recorded responses on standard formstat Information vas obtained from eaah angler on the period of tibe they hadopent angling,. species sought, tackle type used (bait, fliee or s: lures), number and origin (hatchery. or wild) of each apesies yo kept, and the number and origin of each fish releawed fotmper

\section{good: Utilization}

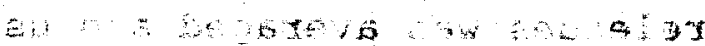

In conjunction with the overali experimental de ipuncoms interactions studies, Central Washington Univerathy derelopediand implemented coordinated research on the food hobits of ohatohery and wild steelhead and resident rainbow trout Their 
experimental design involved collection of 30 hatchery-rear\& steelhead, 30 wild steelhead swolts, and 30 wild rainbow trout during the spring of' 1991. The food utilization work is ongoing and future reports 111 include a more complete treatment of their results. Gut contents of each fish were collected by stomach lavage (Light et al. 1983). Stomachs were removed from dead fish collected from the traversing fyke net in the North Fork of the Teanaway River. These stomachs were placed in 70 . alcohol in the fleld for later identification. Food items were -classified to order using a dissecting microscope. Volume of prey categories by order was calculated using the fluid displacement method.

\section{Data Analyses}

\section{Downstream Migrant Eaumeration}

We believe that the trap in Jungle Creek captured 1008 of the fishes migrating downstream during the period it was operational. The daily counts of fish passing this location required no expansion factor.

Capture data for the entire period of fyke net calibration releases was averaged and used to estimate the number of hatobery steelhead that enfgrated from the North Fork of the Teanaway River before lay 31, 1991. Average oapture efficiency was used because no flow data were available to factor into the calculations. Adjustments were made for the period of each 
sample day when the net was not fishing., as wall as forsthe sample days when oniy hours of darkmess were anpled. Flow data were not avallable for inclusion un this repoxt, so it mas nota possible to determine what efect, if any, fow had on capture efficiency. Water temperature was compared to eapture efficiency results and no significant rolationship was found, no adjustment in the datiy expansion was made for water.$:$. temperature. slightly different equations were ned to calculate daily passage estimates for perlods. when the net was fished 24 ' hours a day and when the net was lished on\&y at night. phene: figures were added to estimate total pastage. Far periods when the net 'was fished 24 hours per day, 99.3t of altisalmonlds were captured durfing the hours "of darkness. The equations used ta estimate daily passage-at the traversing fyse net are shoin below.

For 24 hour sample periods: $\left.N=C A E+\left(f C / M_{i}\right)\left(M_{0}\right)\right)-21 \ldots$

For night only sample pertods: $v+\left[0 / 0+f\left(0 / x_{4}(48)\right)\right] / 0.993$

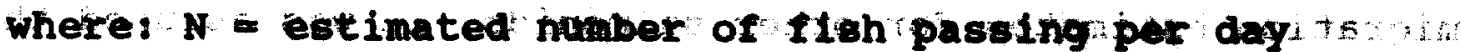

$C=$ number of fish captured

$E=$ exparrion fadtor (fromodibbat ion relefeae)

$M_{i}=$ number of minutes net was fished

$H_{0}=$ number of uinuted net was trotif ished

$0.993=$ correction for periods of night sampling 
When the average expansion factor $(2.98)$ was used to. calculate estimated total outmigration of hatchery steelheac, the estimated total $(34,615)$ was greater-than the known number of fish released $(31,542)$. This overestimate, ar vell as the violation of the first assumption associated with determining downstream migrant trapping efficlencies (that all masked fish-. migrate past the net), caused us to suspect that the actual; average capture efficiency was higher than the data would indicate- $\therefore$ A range of total passage estimates (based on the range of measured capture efficiencies from 1.2 to $6.4 \%$ ) were. calculated. Based on the number of non-migrating fish obearved near the calibration site, we feed that even the highest meanured capture efficiency (6.4\%) may underestimate the actual trap: efficiency. For purposes -of discussion only, an adjusted, . . ., estimated average capture efficiency of $5.0 \%$ was used.

We could not determine the extent of mortality and/or residualism of hatchery steelhead ued in allbration tests Field, observations showed the latter to be fairlywidespread in the area where these fish were released. To develop downstream migration, estimates for other salmonids, it was assumgd that naturally produced salmonids exhibited the eame susceptibility to capture as the hatchery steelhand used in the tests.

In the future, efforts will be made to improve the efficiency estimates of migrant traps in this portion of the study. Using known migrants, and releasing fish closer to the 
trap location may provide mors accurate estimates of capture efficienoy. When more accurate efficiency estimetes are available, we will recalculate thesumber of tish captured ing 1991. Accordingly, the passage estimates in this report should be considered preliminary.

\section{is Rar Ing Irea survero}

Population estinate data were analyzed using methods . identical to these previously described for tributarles fena. Baseline 'Phase, thisreport).

\section{Onderwater Observations}

Data from all sites were pooled for each sample day andy numbers, species and sizes of fish were summarized. The . . . . . frequency and occurrence of various behaviors were expressed as per fish per unit of observation time. Torinventlgated bo: behavior might have changed as a function ofitime, behavior frequency was regressed against number of days after release The number of observation per minute for each grouponas also regressed agalnst date to determine whether relative denstty changed in relation to number of days after releasev ish vere released in three groups between May 6 and May 15 rand it waronot possible to distinguish individuals from the three releases. For consistency in data analyses, a release date of May 6 was assigned to all hatchery fish $(48 \%$ of the fish were released on 
May 6, 35\% on May 8, and $17 \%$ on May 15) * This standard may have affected data interpretation to some degree, but the overall impact was assumed to have been negligible.

Creel Survey

Creel survey data were summarized to provide a minimum estimate of the number of hatchery steelhead andresident fish harvested in the immediate study area during the first two weeks of June. Staff resources available to conduct-this creel survey were relatively low and no efforts were made to generate an estimate of total harvest or total angling pressure. The estimated number of fish caught per hour was calculated by dividing the total number of fish oaptured by the total number of hours fished.

\section{Food otilisation}

Food-utilization data were analyzed by CwU (S. Urakawa, CWU). Analyses to date have consisted of calculating percentages of each food category by volume for eaah group of fish for the spring; 1991 sample. Food items were classified dop to order. Availability. of food was also detemined, but will not be 15 included in this report. 
Experimental Releases

The hatchery-reared steelhead that were released into: Jungle Creek did not appear to have many of the typical external characteristics of steelhead smolts. Mean lengths of hatchery steelhead released into Jungle Creek were $201 \mathrm{~mm}(\mathrm{~N}=50$; SD = $16.2)$ and $174 \mathrm{~mm}(\mathrm{~N}=50 ; \mathrm{SD}=16.8)$ on the release dates of May 8 and May 15, respectively. The percentage of sexually mature fish was 4.0 and 2.9 (all males) for those same release groups." Mean condition factor for the May 8 release group was 0.980 (SD $=$ 0.059). Of the fish for which sex was determined (via internal examination), $72 \%$ were females and $28 \%$ were males. Sex wis determined for fish from the second release group only.

\section{Traversing Fvke Net Calibration Releases}

Expansion factors used to generate emigration estimates with the traversing fyke net ranged from 1.2 to $6.4 \%$ and averaged 2.9\% (Table 10). As stated previously in this report une: of the 2.9\% expansion factor provided an emigration estimate totalinge more than the number of figh released. We felt that the: . . incidence of residualism and/or mortabity in the 1.2 kn between the efficiency release site and the fyke net was high.

Snorkelers observed marked fiah from several of the efficiency release groups-in-the release area after the finad 
Table 10. Results of the traversing fyke net calibration releases in the North Fork of the Teanaway River during spring, 1991.

\begin{tabular}{lrrrr}
\hline \multirow{2}{*}{ Date } & \multicolumn{2}{c}{ Number } & \multirow{2}{*}{ Expansion Factor (₹) } \\
\cline { 2 - 4 } April 22 & 260 & 7 & 2.8 \\
April 22 & 260 & 17 & 6.4 \\
April 24 & 254 & 5 & 2.0 \\
April 24 & 250 & 3 & 1.2 \\
April 29 & 250 & 5 & 2.0 \\
April 29 & 249 & 4 & 1.6 \\
May 01 & 250 & 8 & 3.2 \\
May 01 & 250 & 12 & 4.8 \\
May 20 & 250 & 7 & 2.8 \\
May 20 & 250 & 5 & 2.0 \\
TOTAL & 2523 & 73 & 2.9 \\
MEAN & & & \\
\hline
\end{tabular}

efficiency test group was released. Only hatchery-reared

steelhead saolts were-used'to measure capture efficiency, thus it was assumed that other-groups-of fishes migrating past the trap had a similar chance of being captured in the net.

Hatchery steelhead were the most numerous salmonid group: emigrating from the NFT (Table 11). The calculated value of the high estimate (using $1.2 \%$ aapture--efficiency) of the number of. 
hatchery steelhead emigrating was 83,542. This figure is obviously an overestimate, because only 31,542 fish were released ('there were no other rekeases in the area that may have atrayed past the trap). Because it is impossible to opserve more fish than were released, the total number of fish released was used sas the upper limit on the range of estimates for the number of. hatchery steelhead passing the fyke site. The figure corresponding to the 5.0 efficiency is, as previously stated, presented for purposes of discussion only.

Table 11. Estimated number of salmonids mignating past the traversing fyke net in the North Fork of the Teanaway River between May 6 and May 31,1991 . The range of estimates was hased on the range of measured capture efficiencies. Numbers calculated using a 5.0 vapture efficiency are presented for purposes of discussion only.

\begin{tabular}{lrr}
\hline Salmonid Group : & Range & 5,08 eptimate \\
\hline Hatchery Steelhead & $15,728-31,542$ & 20,109 \\
Wild Steelhead Smolts & $789-4,190$ & 1,009 \\
Trout" and wild steelhead Presmolts $648-3,441$ & 829
\end{tabular}

Includes rainbow, cutthroat, putative hybrid;- and bull trout.

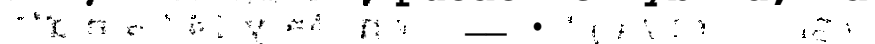

Downstream Passaae

Passage Estimates at the Traversing Fyke Rot

The vast majority (>898) of the salmonids emigrating from NFT were hatchery-reared steelhead that had been released in 
Jungle Creek. The first fish from a Jungle Creek release to be captured in the fyke net was captured approximately $7 \mathrm{~h}$ after it was-released. This fish traveled an average of $1.6 \mathrm{~km} / \mathrm{h}$. Using a 5.0\% efficiency, approximately 20,109 (64\%) of a total of 31,542 hatchery steelhead smolts released into Jungle Creek would have emigrated from the North Fork of the Teanaway River before June 1, 1991 (Table 11).

Wild steelhead smolts comprised over half of the wild salmonids captured in the fyke net -(Figure-la). In general., wild steelhead were longer than rainbow trout and wild steelhead presmolts, while hatchery, steelhead were', on average, longer than wild steelhead (Figure 13). Condition factort were very similar between wild $(C F=1.010 .(S D=0.09))$ and hatchery $(C F=1.007$ $(S D=0.12))$ steelhead. The condition factors of the hatchery steelhead that were captured in the fyke net were initial\&y slightly higher $(C F=1.055(S D=0.068))$ than the subsample examined at time of release $(C F=0.980(S D=0.059)$. Mean condition factors of hatchery steelhead captured in the fyke net, however, decreased from $1.055(S D,=9.068)$ between April 22 and May 5 to $0.891(S D=0.070)$ between May 24 and May 30. This information suggests that the more robust fish migrated more promptly than their more slender counterparts, It may also suggest that the general health (assuming condition factor is a measure of health) of the hatchery fish decreased after release. 


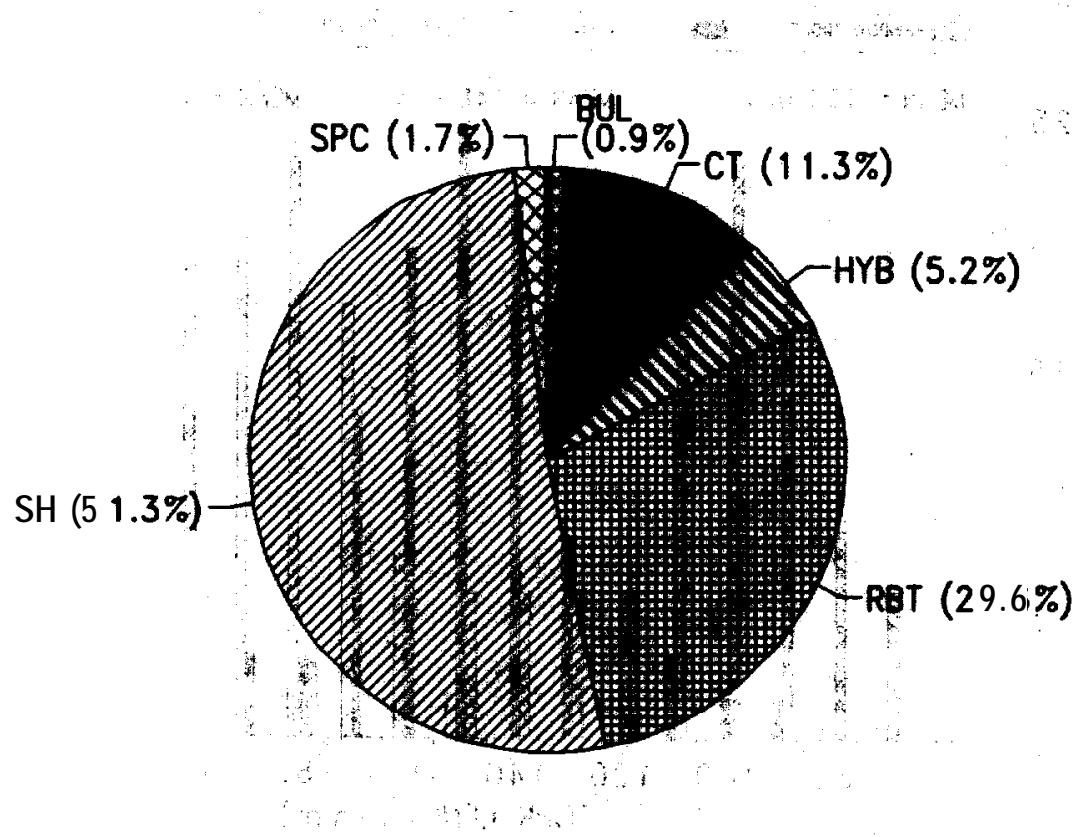

Figure 12. Species componition of wild nalmonida $(A B=.145)$

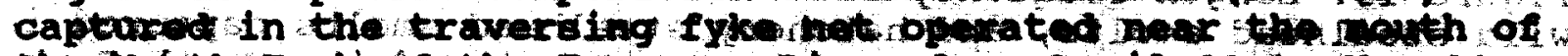

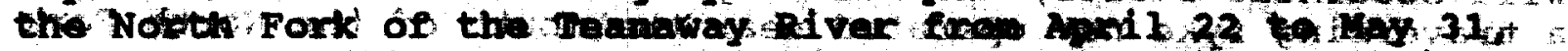

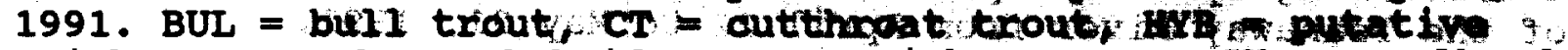
rainbow $x$ cutthroat hybrid, $\mathrm{RBT}=$ rainbow trout, $\mathbf{s H}=$ steelhead, $\mathrm{SPC}=$ spring chinook salmon.

$\therefore$ Jusing the efficiency of $50 \mathrm{~s}$, bapproxtmatedy 64 of the

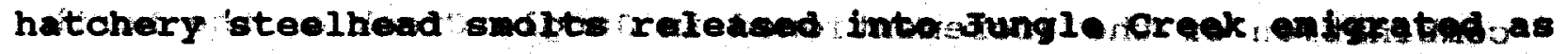
far as the nourth of the warth Fork before June $1, y$ of the $36 \%$ of the hatchery steelhoad that did not emlgrate from the NFT 


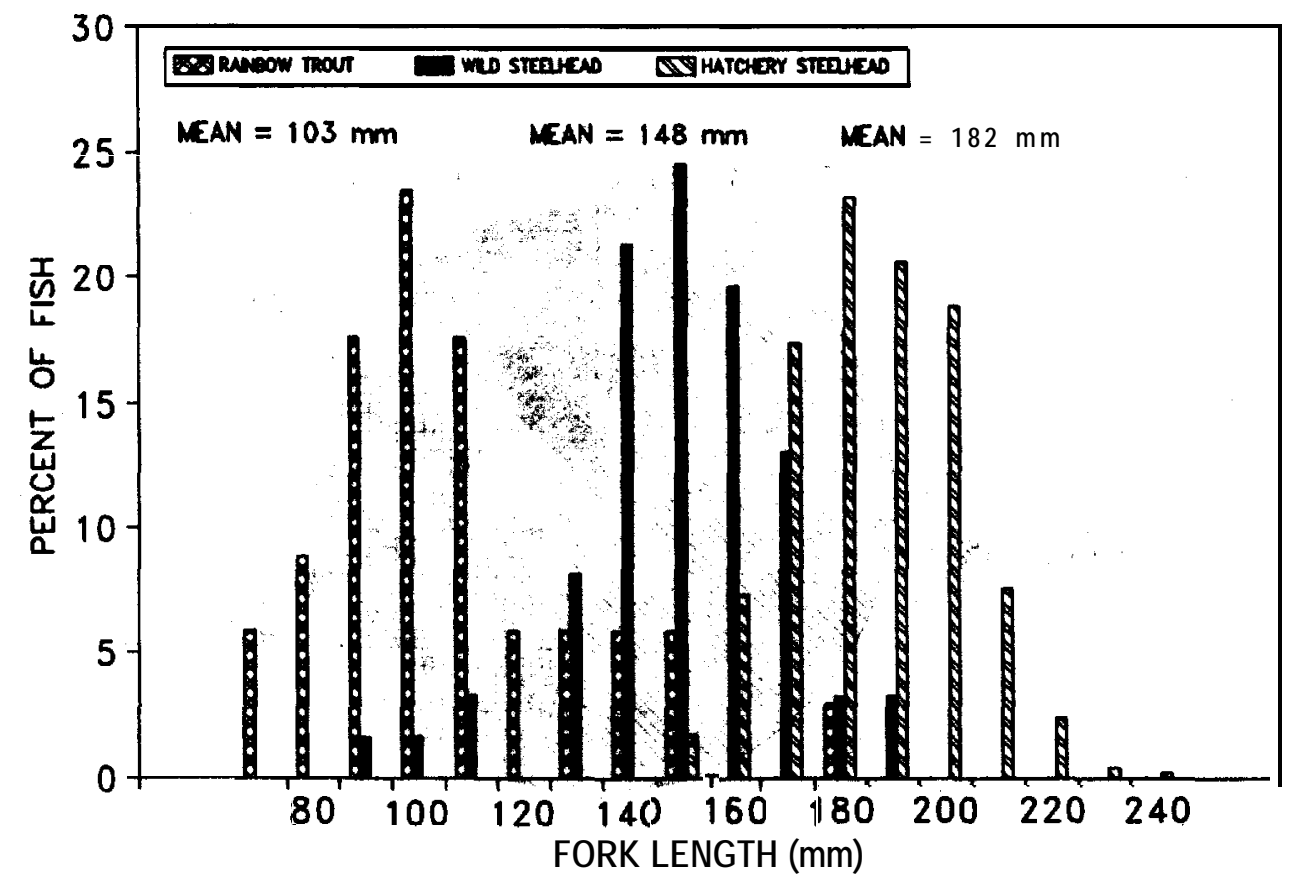

Figure 13. Length frequency distribution of wild rainbaw tront wild steelhead smolts, and hatchery steolhead smolts captuned in a traversing fyke net operated near the gnouth of the Nowth fort of the Teanaway River from April 22 to May 31, 1991. : . : wet:

before June 1, it was not possible to determine what portions were removed by predators and anglers, died, residualized or a combination of the aforementioned in Jungle Creak or the North: Fork of the Teanaway River. Snorkel surveys, as well as areal surveys, suggested that residualism was very widespreadiand 
accounted for the maforlty of the matchery eteelhed that did not emigrate prior to: June 1 .

Non-salmonid fish species captured in the fyke net included longnose dace, sculpins, and suckers. However, these species were not enumerated. Plans for 1992 sampling will include the enumeration of ali species.

\section{Diel Movenents}

During the periods when the fyke net was operated $24 \mathrm{~h} /$ day, 99.3\% of all salmonids were captured during hours of darkness (18:00 to 08:00 PDT) (Table 12). Similar diel patterns have been found by other researchers working with Yakima basin salmonids (Busack et al. 1991) and elsewhere (Ledgerwood et al. 1991). Trapping in the lower Yakina River ind fated that 980 of downstream movement by juvenile salmonids occurred during hours

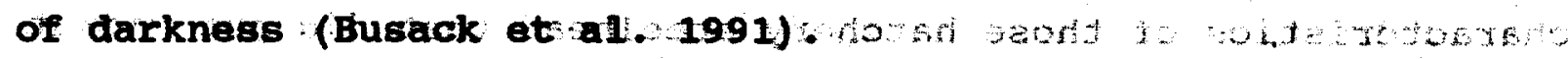

\section{Downstream Rassage riming bae 9129546

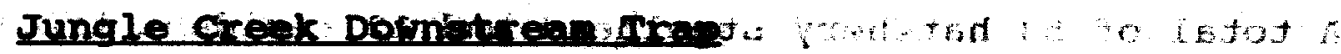

Downstream paseage of hatchery setres lbead in Jungie Godak

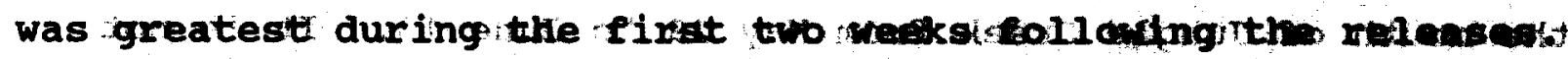
However, the Jungle Creek trap was not oprented dunding she pak

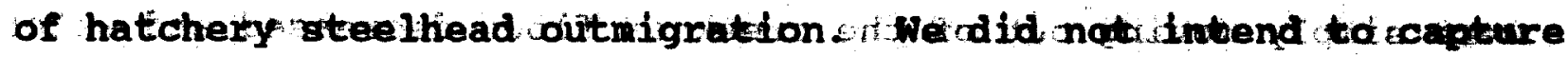
all salmonids passing during peak enigration, but instend wase interested in examining the movement timing and biological 
Table 12. Number and peroentage of salmonids captured during day (08:01 to 17:59 PDT) and night (18:00 to 08:00 PDT) in the North Fork Teanaway traversing fyke net between April 22 and Aprk 29 . and between May 6 and May 12, 1991.

\begin{tabular}{|c|c|c|c|c|c|}
\hline \multirow[b]{2}{*}{ Species/Group } & \multicolumn{3}{|c|}{ Dav } & \multicolumn{2}{|c|}{ Niaht } \\
\hline & $\mathbf{N}$ & . & Percent & $\mathbf{N}$ & Percent \\
\hline Hatchery Steelhead & 4 & & 0.5 & 814 & 99.5 \\
\hline Wild Steelhead Smolts & 1 & & 3.2 & 30 & 96.8 \\
\hline Rainbow Trout & 0 & & 0.0 & 10 & 100.0 \\
\hline Cutthroat Trout & 0 & & 0.0 & 1 & 100.0 \\
\hline Hybrid Trout' & 1 & & 100.0 & 0 & 0.0 \\
\hline Spring Chinook & $\mathbf{0}$ & & 0.0 & 1 & 100.0 \\
\hline & & & & & as is \\
\hline TOTAL & 6 & $2 \cdots$ & 0.7 & 856 & 99.3 \\
\hline
\end{tabular}

Putative cutthroat $x$ raihbow trout hybrid

characteristics of those hatchery steelhead that did not migrate out of the creek within the first two to three weeks after they were released.

A total of 53 hatchery steelhead and 12 redient trout (8 rainbow and 4 cutthroat) were captured in the trap operated at the mouth of Jungle. Creek from May 29 to June 13. It is not clear whether these fish were emigrating as smalts or if they ry were simply moving out of the creak as flows decreased cand water temperatures increased. Observations of the physical appearance 
of the efah captured auggested the latter espario wa more 11kely. Over 268 of the hatcheny beglwead rand thrme of the eight (38\%) rainibow trout were resually nature malas a finlif of the cutthroat trout captured were also in spaming oondition fone

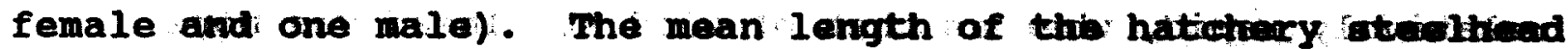
captured was $200 \mathrm{~mm}($ SD $=25.1)$, while the wean lengths of the

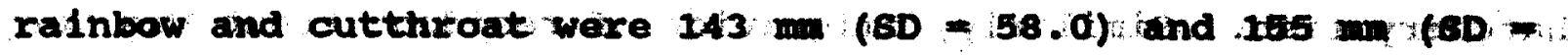
26.9), respectively. Relatively high percentages of precoctens male hatchery steelhead and sexually mature restdant trout were in the stream at the same time." Noreover, the length of the hatchery-steelhead was larger than the repident trout, poesibly

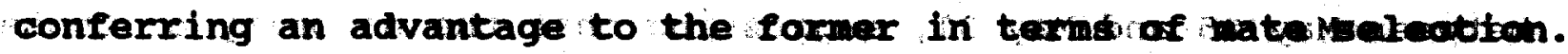

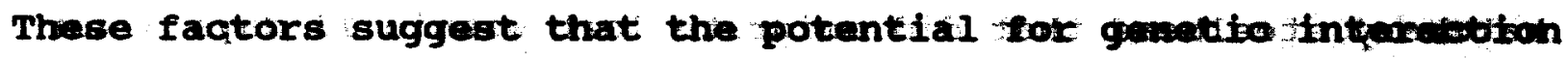
between resident trout and residual hatchery ratee houd was $\mathrm{pal} a \mathrm{~d}$ substantial in 1991 (Flaming and Crow 1992).

North Fork of the Tatarrativiara tes?

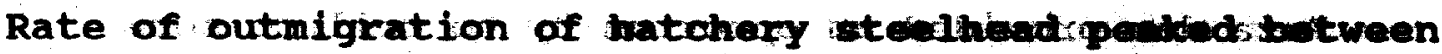

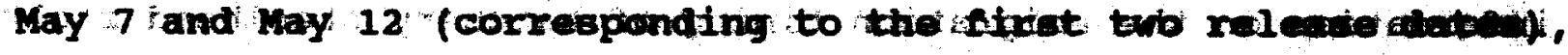

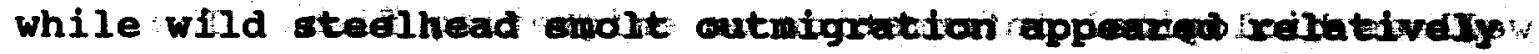

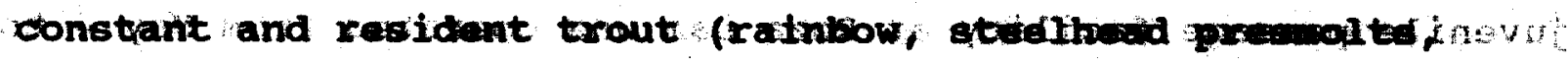

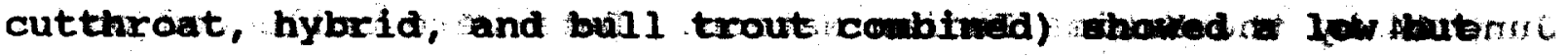

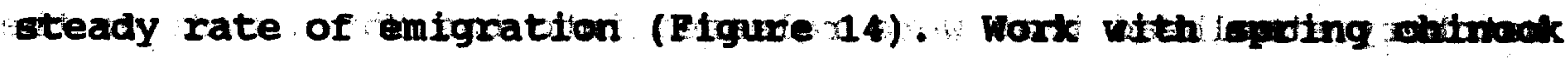
salmon suggests that large numbers of enifgrating hatchersintah 
may induce-a 'pied-piper' effect in coexisting wild fish, causing the latter to outmigrate prematurely (Hillman and Mullan 1989). No evidence of this behavior was observed in the present study in 1991. Instead, the outmigration rate of hatchery smolts was...: relatively rapid, whereas that of wild- steelhead was wore if: prolonged, having begun well before the first large releases of hatchery fish. Simflarly, 'emigration of resident trout. wax' very protracted, with few well-defined surges in activity-, none of .. which corresponded to pulses in hatchery steelhead movement (see Undertwater Observations, this report).

Downstream passage of hatchery steelhead smolts was lowest between May 25 and May 31, suggesting that the majority of those hatchery steelhead that did emigrate left within 10 days aftar? being released. Estimated numbers of hatchery steelhead anolte. emigrating per day (calculated using a 5.0\% efficiency for : discussion purposes only) are presented in Figure 15 .

\section{Roza Dam Juvenile Passage Facility}

Roza dam provided an opportunity to collect some information on the emigration timing hatchery steelnead smolts as well as biological information on emigrating fish. The juvenile passage facility at Roza Dam-was operated from uny to to June 14 by the Yakima Indian Nation. Data wer collected on hatchery steelhead that were released into the North Fork of the Teanaway River and Jungle creek. The first hatchery steelhead 


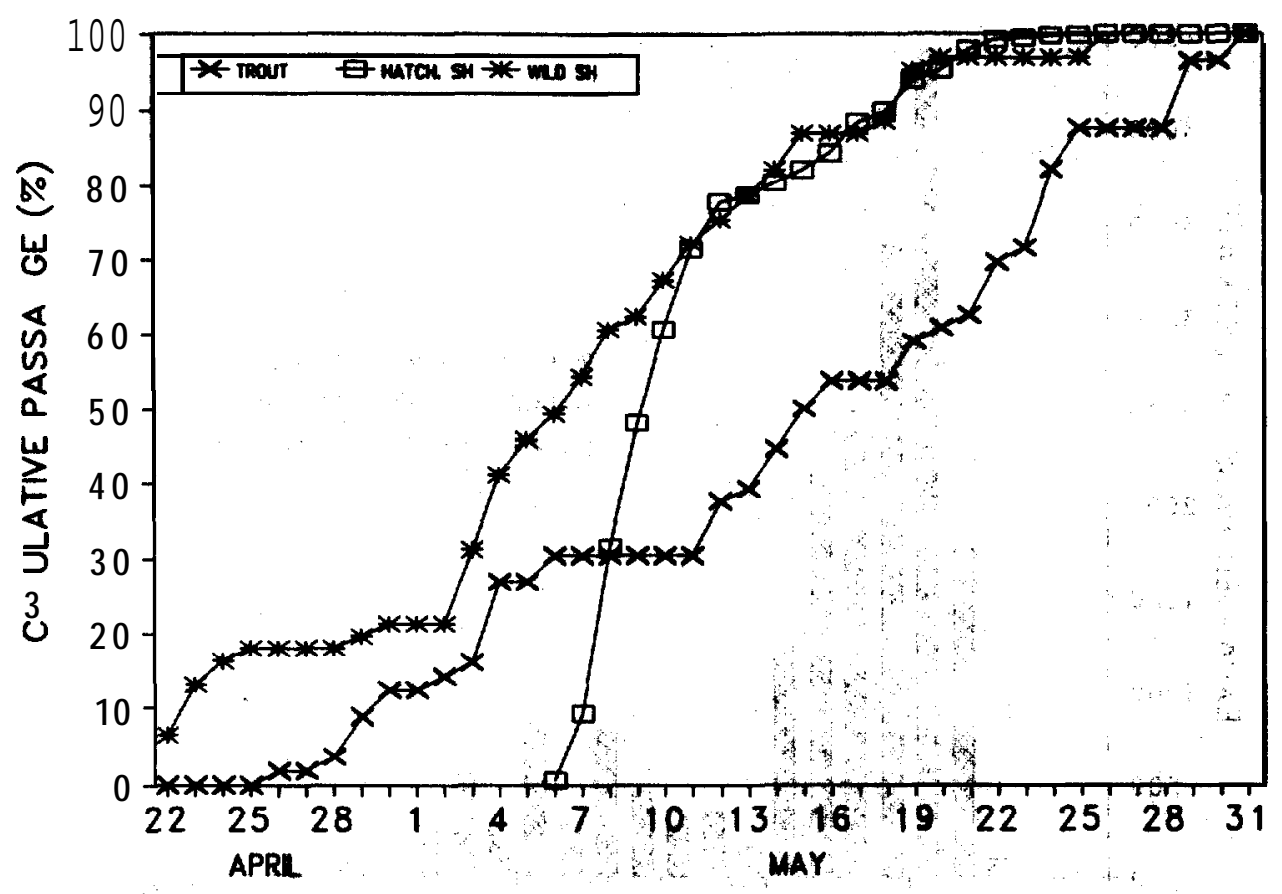

DATE

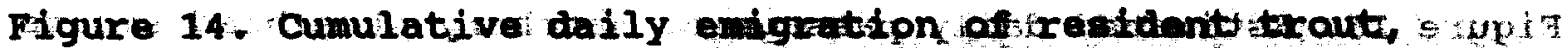

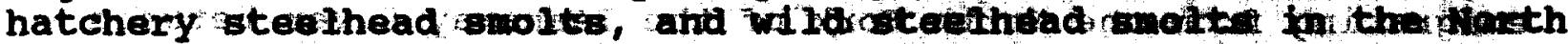
Fork of the Teanaway River, from April 20: to Nay 31 ig9u. :gA

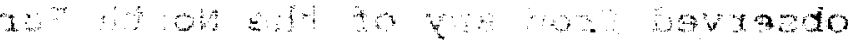

in

in

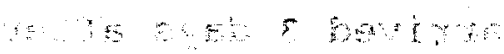

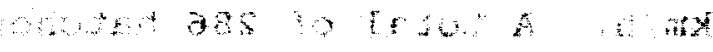

$\therefore$

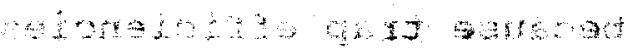




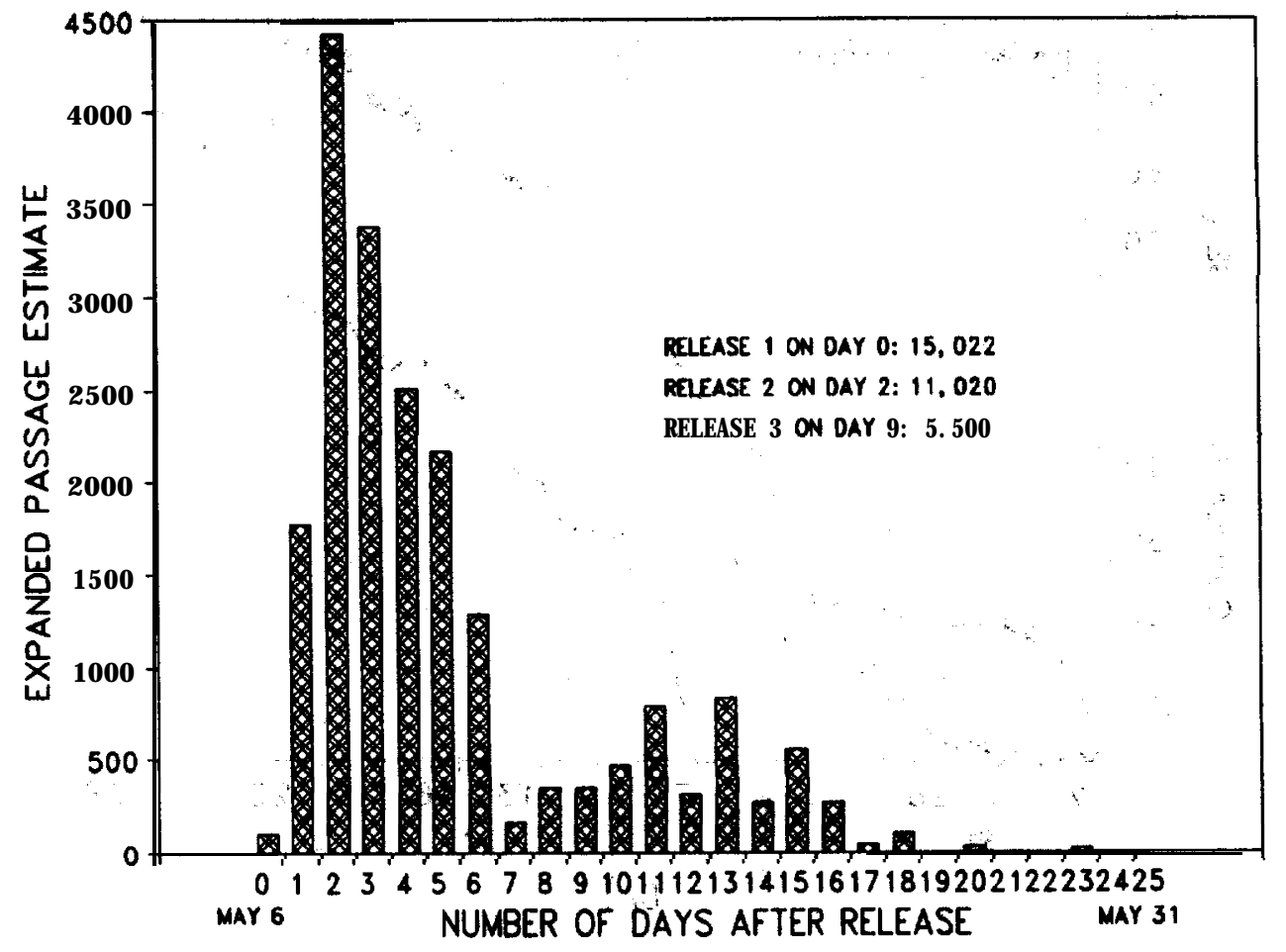

Figure 15. Estimated daily passage of hatchery stenlhead smolts emigrating from the North Botk of the Temantay River between April 22 and May 31, 1991. 0,1

observed from any of the North Fork releases arrived at Roza Dam arrived 3 days after it was released, migrating approximately 1.8 $\mathrm{km} / \mathrm{h}$. A total of 286 hatchery steelhead were observed. Expanded estimates of total numbers passing Roza Dam were not available because trap efficiencies at Roza Dam were not calculated. Data was obtained on the size of the hatchery steelhead captured at 
Roza Dab bver the. Resultis of correlution analytes indlcathas"

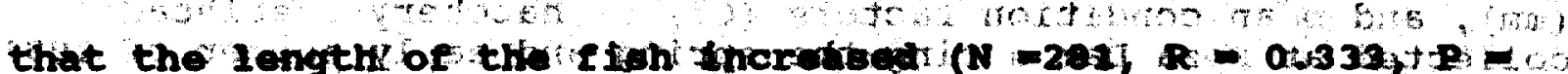
$0.000)$ while condition factors decreased over time $(N=223, R=$ $-0.159, P=0.017$ ) (Tabre 13)

\section{Prosser Dam Juvenife Passage Facility}

A fuvenile passage facility at Proseer Dam was operated by the YIN. The YIN obtained data on emigration timing, number of hatchery steelhead passing Prosser Dam, and biological

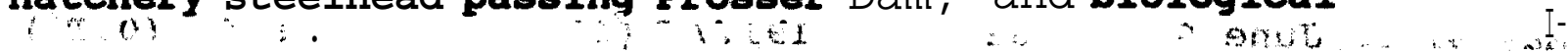
information on hatchery steelhead released into the North Fork of the Teanaway River and Jungle Creek. A total of 225 hatchery steelhead were captured between April 22 (the first day of calibration releases) and July 10. Estimates of the total number of steelhead smolts from releases in the North Fork and Jungle

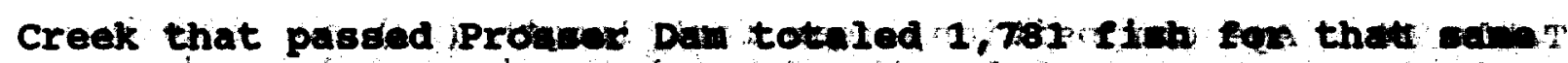

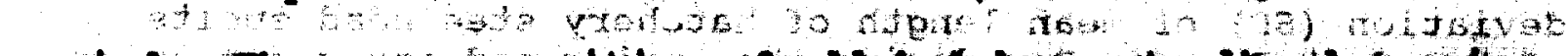

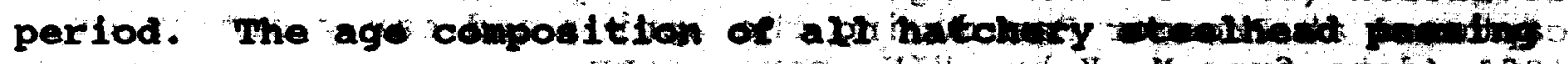
the dam reflected a mixture of age 1,2 , and 3 fish (Table i4).

In 1991, approximately 34,065 hatchery steelhead onolts were released into the North Fork os the Teantway River and Jungle Creek (31,542 into Jungle Creek between May 6 and 15 and 2,523 into the North Pork for calibration releases between April 22 and May 20). In addition, 5,113 fish were released above Roza Dam between April 10 and May 24 by other researchers in an attempt to determine trapping efficiencies at the dam.

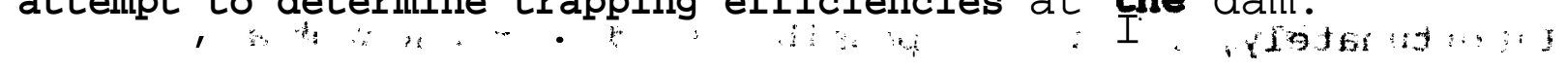


Table: 13.. Capture periods, sampla sires. (N) , mean fork dengtha $(\mathrm{mm})$, and mean condition factors $(C F)$ of hatchery steelhead collected at Roza Dan during the opring and earl $Y_{1}$ eymmex pf 4991.

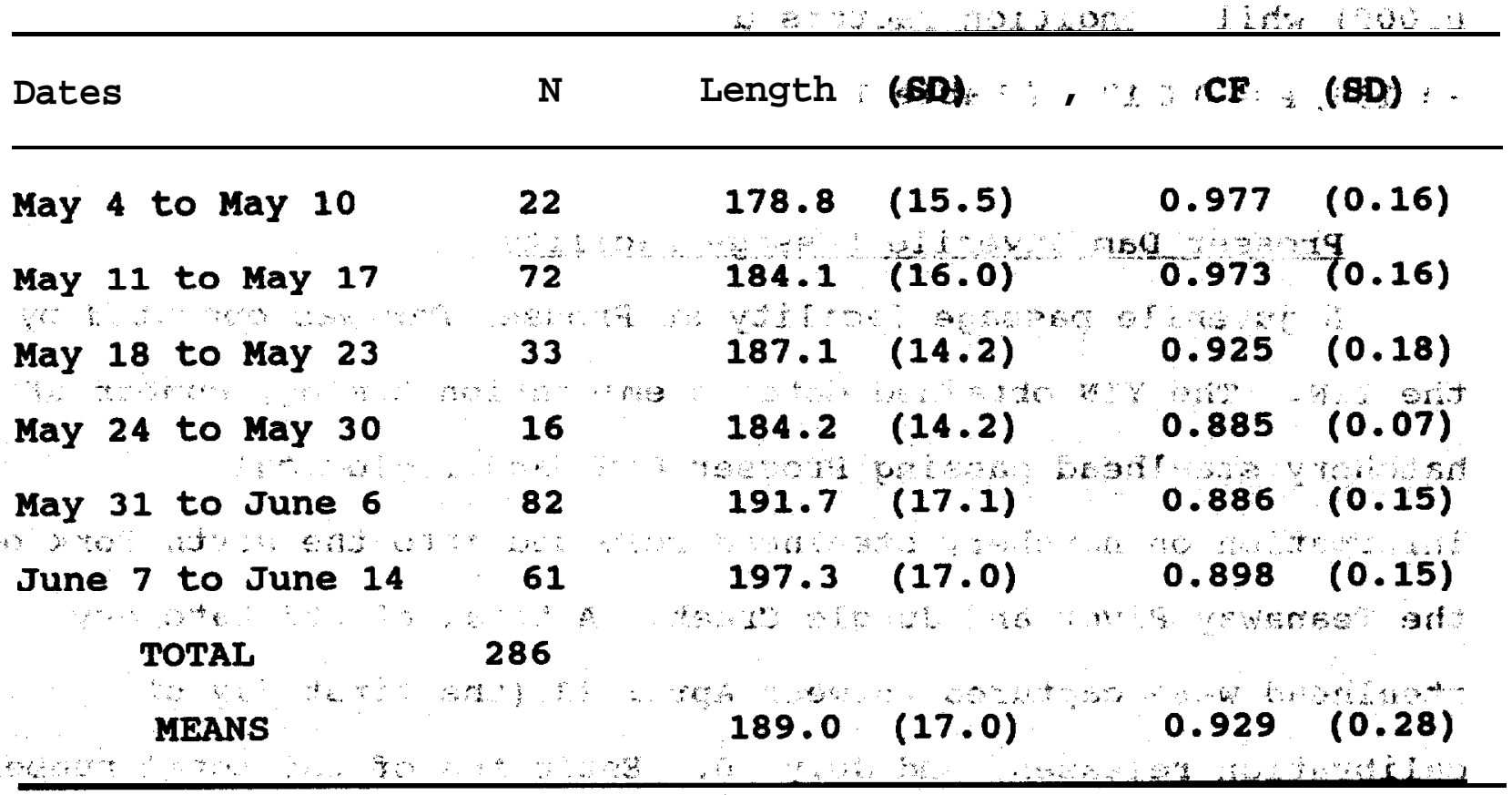

Table 14... Age composition 0 mean fork length (nm) and atandard deviation (SD) of mean length of hatchery steelhead smolts

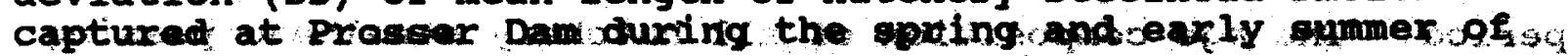
1991 (data from M. Kohn, YIN, pers. comm.).

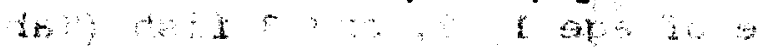

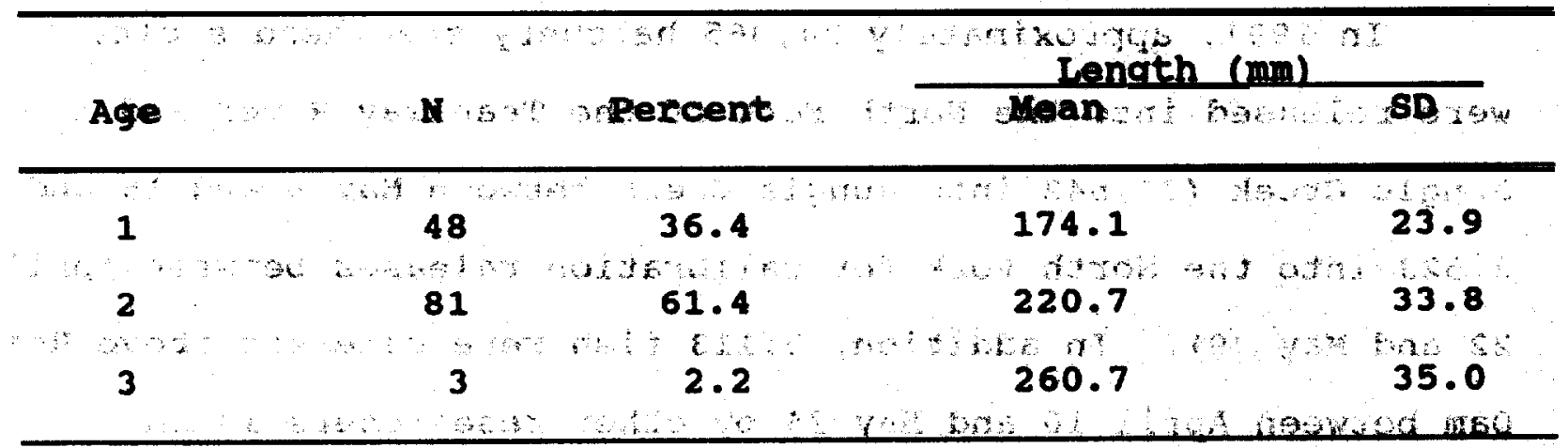

Unfortunately, it was not possible to determine what proportion 
of age 1 ish captured at Prosser Dam were released in the Teanaway system versug noza Dam. Assuming all of the age 1 smolts captured at Prosser originated from the Teanawdy releases and the percentage of that? age group observed reflected the actual age composition of all migrating hatchery steelnead smolts, then a total of 648 smolts $(36.4 \%$ of 1,781$)$ from the Teanaway releases passed Prosser' Dam between the time of their release and July 10. Estimated daily passage at Prosser varied widely but appeared highest during the second week of June (Figure 16).

Survival of the smolts to Prosser Dam would haye been slightly less than 2.08. Unknown portions of the remaining 98\% of those fish presumably died or residualized in the $241 \mathrm{~km}$ between Jungle Creek and Prosser Dam. The survival rate of hatchery smolts between the Haches and Kakjwe frivars and Bropger

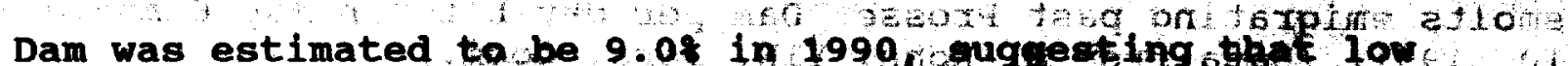
survival and/or high "holdover" or residualism rates may have

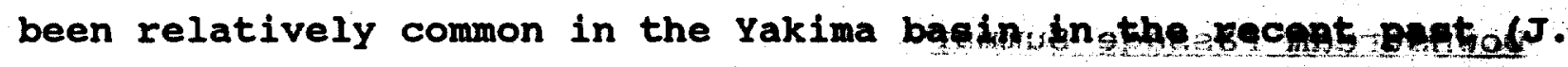
Cummins, WDW, unpubdished datads a

The age 2 hatchery fish coptuxed at Prpsgor Dgo ino 1991 it

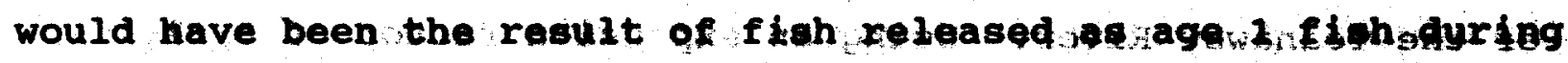

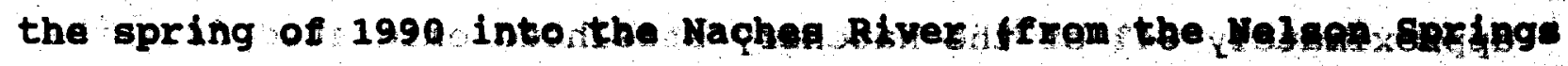

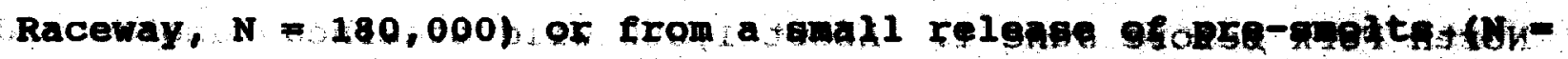
$1984)$ released from the Yakima Hatghefy into widg Holtowogrgek on November 30,1989 . 


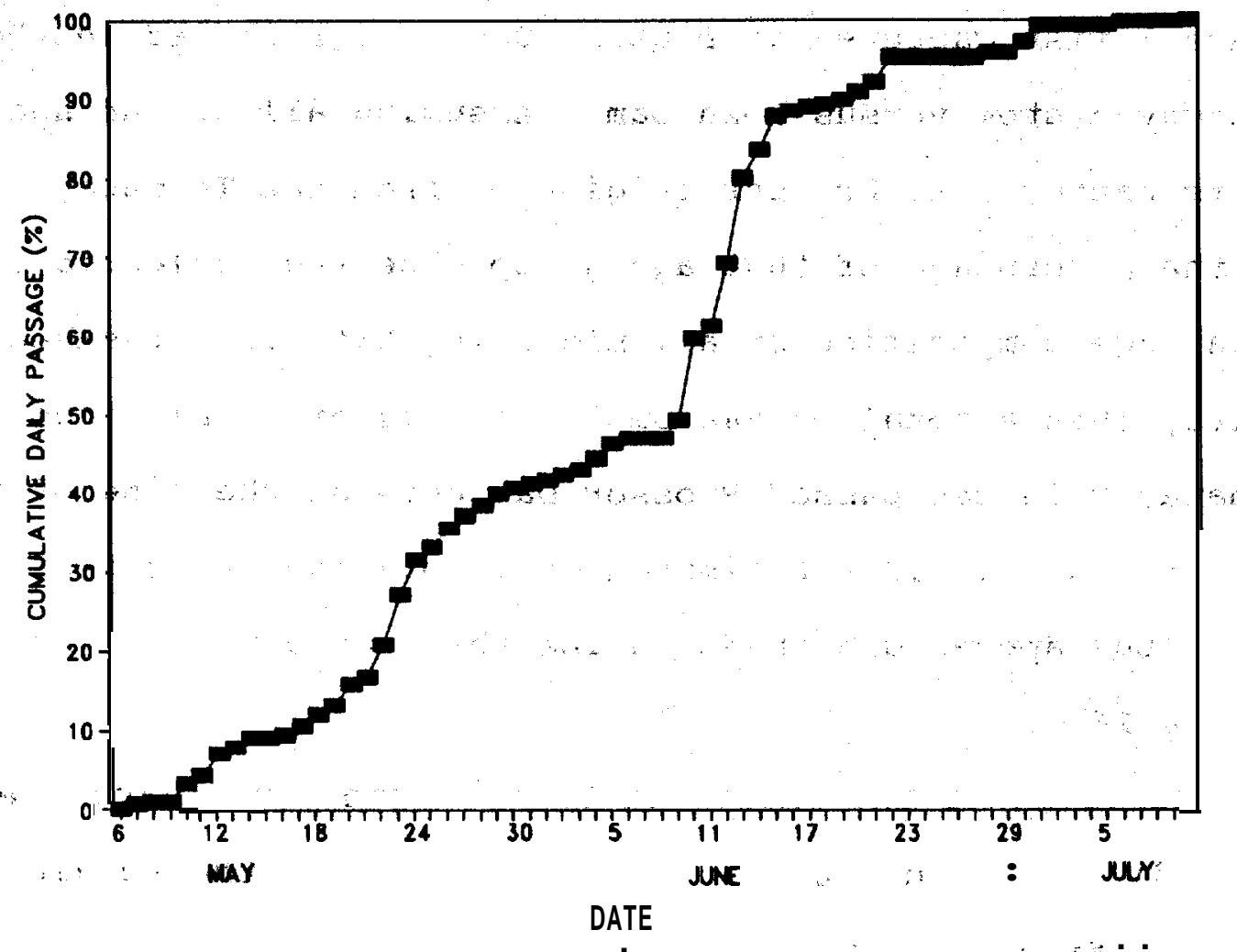

Figure 16. Cumulative estimated passage of hatchery steelhead smolts emigrating past Prosser Dam per day between May 6 and July 10, 1991 : (Data from H. Kohn, YIF, pers. coma. )

\section{Downstream Passage summary}

Hatchery steelhead accounted' for the mafority of the $i$, an salmonids captured in the traversing fyks net in the North Fork of the Teanaway River. Using an expansion factor of 5.08, approximately 648 of the hatchery tedihead enfgrated from the North fork before June 1. About 1,000 wild steenkead smolts and over 800 resident salmonids for juvenile wild steelhead) were estimated to have migrated out of the North Fork of the Teanaway 
River between ApxiE 22 and May 31. Hatchary steelhead capturad

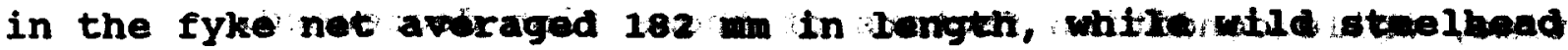
smoles and resident trout fand toelhead presmodtsilayeraged 148 and $103 \mathrm{~mm}$, respectfvely. Host (99.34) of tha salmonids daptwed in the fyke net wore passing the fet during the houss of dapkness (18:00 to 08:00 PDTF:

The potential for Interbreeding between residnal prncocial hatchery steelhead and resident trout was hight Betroen My 29 and June 13, 53 hatchery steelhead, eight rainbow trout and four cutthroat trout were captured migrating from Jung 1 ereal Into the North Fork of the Teanaway River. Most of the hatchary steelhead did not posabss omaraterlistles typical of mplts and

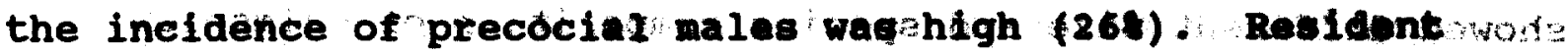
rainbow trout and cutthrbat trout were alsoj in spentag asdition during this period. Th1 Idnding saggests that intecbreding between these groups could occur Enigration rate of hatchery ateelhead at the mouth of the

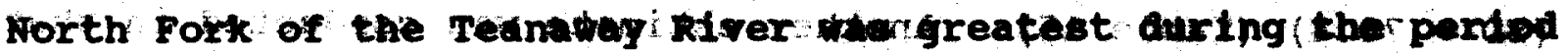

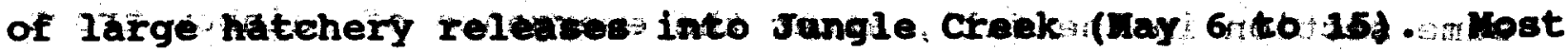

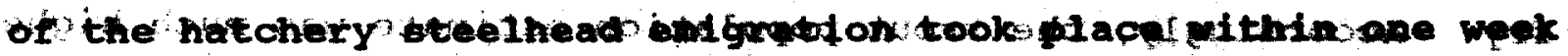

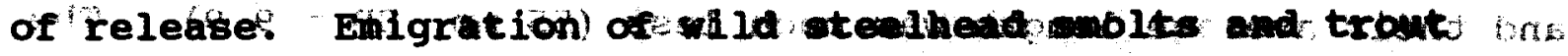

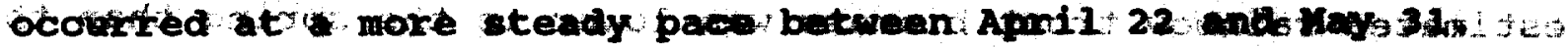

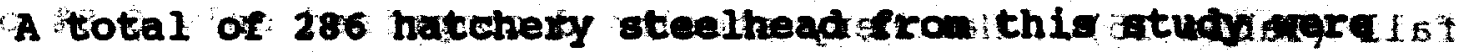
captured at the juvenile passage racillty at Roze Damb The flrst fish to resch Foza Damifoni Jungle creak did so at at ratof 1.8 
$\mathrm{km} / \mathrm{h}$. Lengths of hatchery fish captured at Roza increaced with time, while condition factors of those fish decreased.

An estimated 648 ( $<2 \%)$ of the hatchery steelhead released into-the upper Yakima basin emigrated past Rrosser Dam before. July 10. The majority (617) of the hatchery steelhead passing Prosser were age 2 . This indicated that residualism or "holdover" of hatchery steelhead may have been common in the Yakima basin in the 'past several years.

Population Estirmates

Jungle Creek

-Population estimates in the lover $100 \mathrm{~m}$ of Jungle Creek showed dif ferent size and species composition of salmonids, between opring and fall estimates in 1991 The population estimate conducted in Jungle Creek prior to the release of hatchery smolts indicated a numerical density of 0.024 rainbow trout per square meter. These trout averaged $121 \mathrm{~mm}$ in length $(S D=70.4) \quad($ Table 15$)$. Another estimata was conducted in that same section in the fall, after the emergence of rainbow trout. fry. Accordingly, the trout population estimate was meh higher and their average length was much lesto $(55 \mathrm{~mm}, \mathrm{SD}=9.91$, The estimated- rainbow trout biomass was lowar in the spring that the fall (Table 15). Hatchery steelhead comprised only $6.8 \%$ of the total number of fish in the fall estimate but accounted for $64.8 \%$ of the biomass. The total biomass in Jungle creek was much 
higher after the introdvetion of hatchery teeshead and the concurrent emergence of rainbow trout fry than it vas before the releases- No juvenile spring chinook salmon were observedint Jungle creek during either spring or fall wampling :

Table 15. Estimated population density, and biomass of flsh sampled in Jungle Creek and the North Fork of the Tapnaway River before and after the release of hatchery steelhead smolts in 1991.

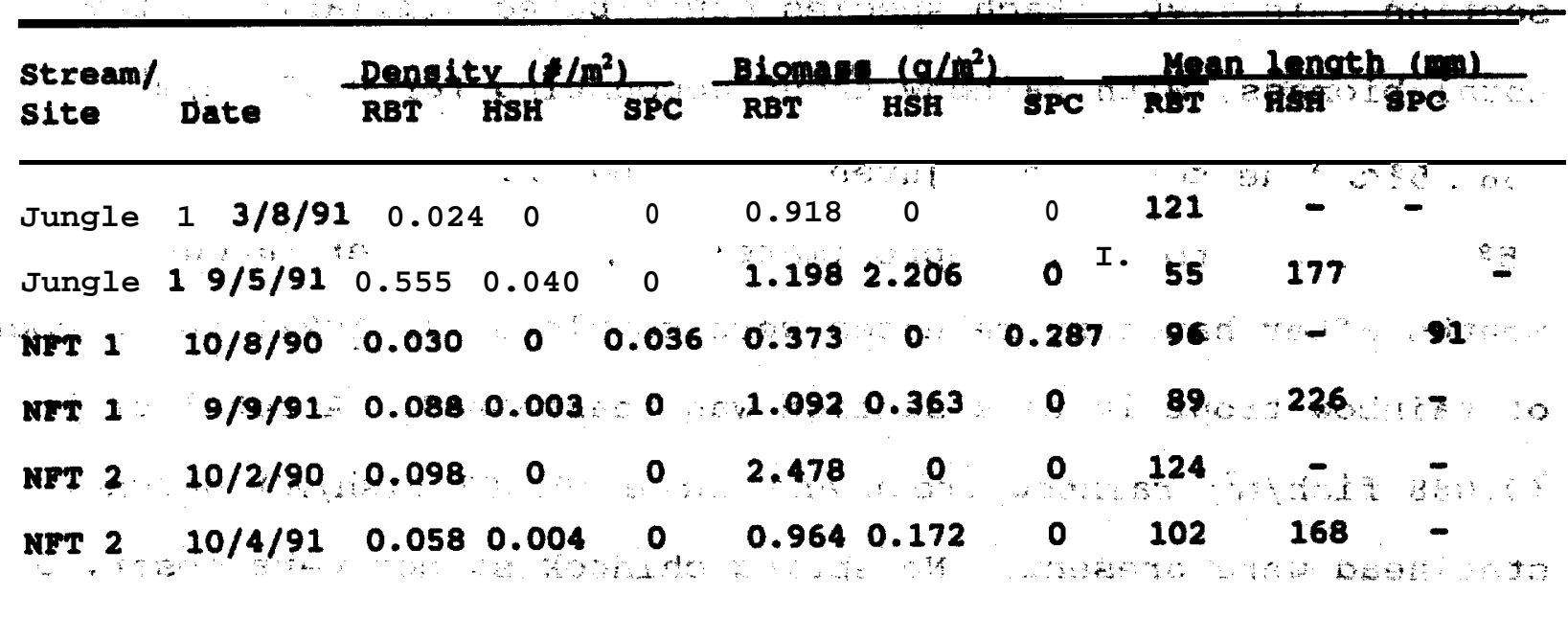

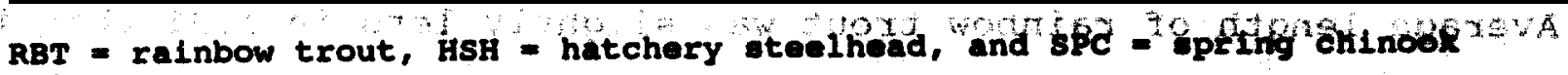
salmon.

Yorth Fork of the Teanaway River

It was necessary to conduct initial pre-release population estimates in the North Fork of the Teanaway River in the fall of 1990 to obtain resident trout density estimates prior to the releases of hatchery steelhead. In contrast to Jungle Creek, we could not conduct population estimates immediately prior to the smolt releases in the spring of 1991 because of high flows. 
Population estimates were conducted in the same sites as those used for the rearing surveys of the baseline phase of this: project.

Population estimates that were, conducted in two study sections of the North Fork of the Teanaway River showed different species composition and biomass-present between fall of 1990 and fall of 1991 . Rainbow trout and chinook salmon were present in section 1 in 1990. Each species contributed similarly to the total biomass, with rainbow trout accounting for $0.373 \mathrm{~g} / \mathrm{m}^{2}$. (56.5\% of the total) and juvenile spring chinook $0.278 \mathrm{~g} / \mathrm{m}^{2}$ (43.5\% of the total). Approximately one year later (about 4 months after hatchery releases were completed in 1991) the number of rainbow trout in this section was reassessed. A total of 76 $\left(0.088 \mathrm{fish} / \mathrm{m}^{*}\right)$ rainbow trout and three $\left(0.003 \mathrm{fish} / \mathrm{m}^{2}\right)$ hatchery steelhead were present. No 'spring chino\& salmon were observved. Average length of rainbow trout was slightly less in 1991 than in 1990, possibly due to an earlier date of sample in 1991. Hatchery steelhead made up only $3.8 \%$ of the numerical density but accounted for $24.9 \%$ of the biomass present. Total biomass was higher in 1991 than in the previous year, possibiy due to the presence of the larger hatchery 'steeihead in 1991.

In section ' 2 in the fall of 1990, rainbow trout were the only salmonid observed. The trout in this section were $A: \infty$ relatively large (Table 15). A year later (about 5 months after 
releases of hatchery etoelbead molte were completed in 199.1$)$ p 42 $\left(0.058 \mathrm{fish} / \mathrm{m}^{2}\right)$ trout were estimated to be in tha gection Mean length was $102 \mathrm{mn}(\mathrm{SD}-34.2)$ and total biomase was te. $964 \mathrm{~g} / \mathrm{w}^{2}$ The average length of the thee hatchery stebzhed observed aude $168 \mathrm{~mm}(S D=16.7)$. These hatchery steelhead accourtied for 677 of the total salmonid density and $15.2 \%$ of the total salmonid

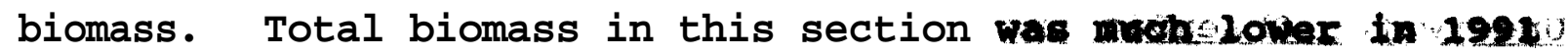
than in $1990 \%$. In conetast to bettow, no epting chlyook were observed in section 2 in elther 1990 or 1991 .

One hatehery steelhead wasi eaptured In a population estimate section (seotion 3) in the North Fork that is $11.2 \mathrm{~kat}$

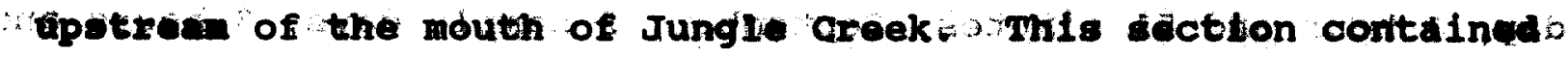

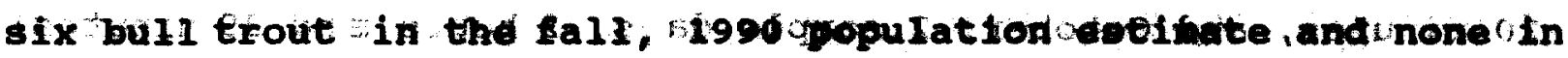
1991 (see rearing surveys in Baseline Phase, this report).

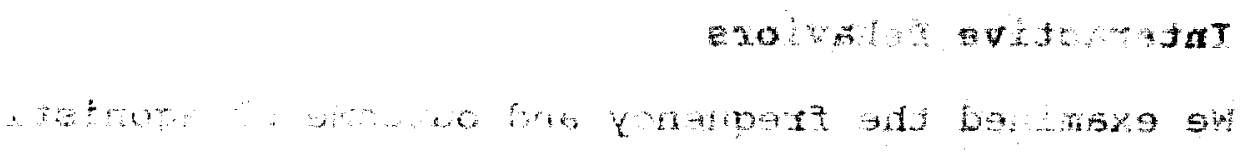

Population Estimate Sutward

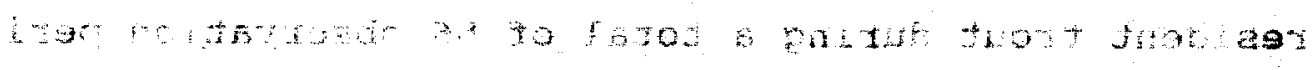

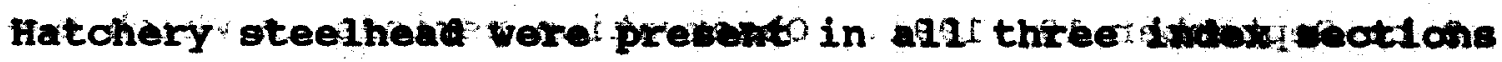

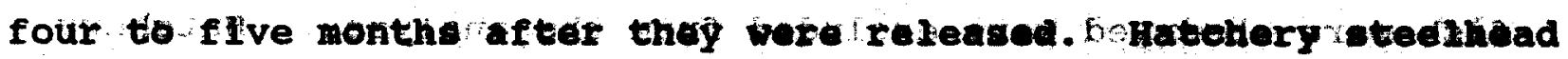

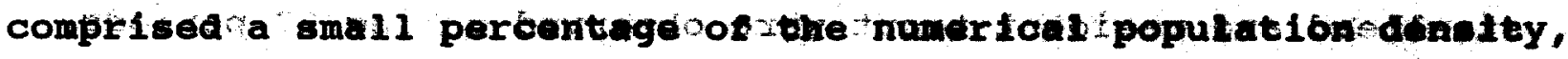
but due to their large alzd accounted for d somentiat zarger is

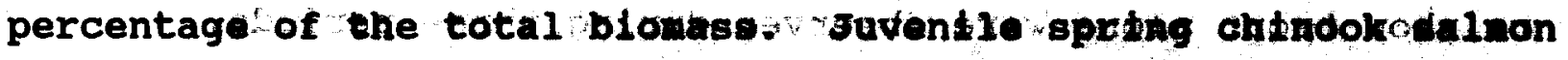
were presentin the lower sedtion of the North took of the roo 
Teanaway River in the fall of 1990 but were aboent in 1991. Hatchery steelhead moved up the North Fork of the Teanaway River a distance of over $11 \mathrm{~km}$ from the mouth af Jungle Creek. This area contained bull trout in 1990 , but none were obeenved there $i \mathrm{n} \quad 19991$.

\section{Underwater Observations}

Sampling intensity was greatest in yayo (1:1 sample days, 39 hours and 29 minutes totaz observation time) and decreasedas the summer progressed (June; 3 samplesdays, 6 hours and 47 minutes, July; 2 sample days, . 4 hours and 51 minutes, August, 1 sample. day, 1 hour and 51 minutes; September, 2 sample days, 3 houze: and 20 minutes, and October, 2 sample days, 2 haurs and 39 minutes).

\section{Interactive Behaviors}

We examined the frequency and outcome of agonistic interactions within and between groups of hatcheryesteplhgagand resident trout during a total of 56 observation periods from May 2 to september $19 ; 1991$. Obseryation periods in which one or no fish were observed were excluded from the tanalyaes. satabery steethead and resident brout were observed duringm 27 periodfinor hatchery steelhead alone, were present during 26 pertods, snd rainbow trout a\&one-were. observed during three per fods $-10 \mathrm{~s}$ Agonistic encounters were relatively frequent in the firat two to three weeks after release of hatchery steelhead and appeared to 
decrease slightly thereafter (Table 16). However, the decreasps were not statistically gigmificant (P>0.05). Agoniatic threate or attacks were observed in 50 o this 56 (a98) perlods. Displacement was noted in 25 'f the 56 (46) cases. Overt agonistic encounters, involving one or more threats, chases, or nips were recorded in 31 of the 53 (58) obsenvation periode in which only hatchery steelhead were observed. Hatchery steelhead were considered to be dominant (usually initiated the attack and were successful in displacing the opponent) over resident trout in 10 of 19 (53\%) contests in which both groups were present, while resident trout were dominant in nine contests (47\%). Agonistic displays (ritualized behavior;) were performed by both hatchery steelhead and resident trout. Prior to making an actual attack, hatchery steelhead appeared to arch dorsoventrally, erect their fins, and lower their head while performing an exaggerated, rigid, side to sipe "wig-wag" movement (Taylor and Larkin 1986). It did not appear that this wig-wag threat was issued without a follow-up attack. This may imply that the hatchery steelhead were not responsive to bluffs or threats. Resident trout assumed a similar head-lower post\&e with very erect fins in symatric and allopatric conditions. Resident trout in allopatry appeared more responsive to bluffs and threats (i.e. not all threats were followed by an attack) than did the steelhead in either allopatry or sympatry. Resident trout were initially much less tolerant of increased fish 
Table'16. Comparisons-of hatchery. steelhead and resident trout behavioral interactions. Behavioral interactions, defined as aggressive agonistic encounters (threats, chases, nips) or displacements (a fish being forced out of a preferred area), per fish per minute are compared to number af days after release, Data were from underwater observations in Jungle Creek and the ' North Fork of the Teanaway River, Way 2 to September- 19, 1991.

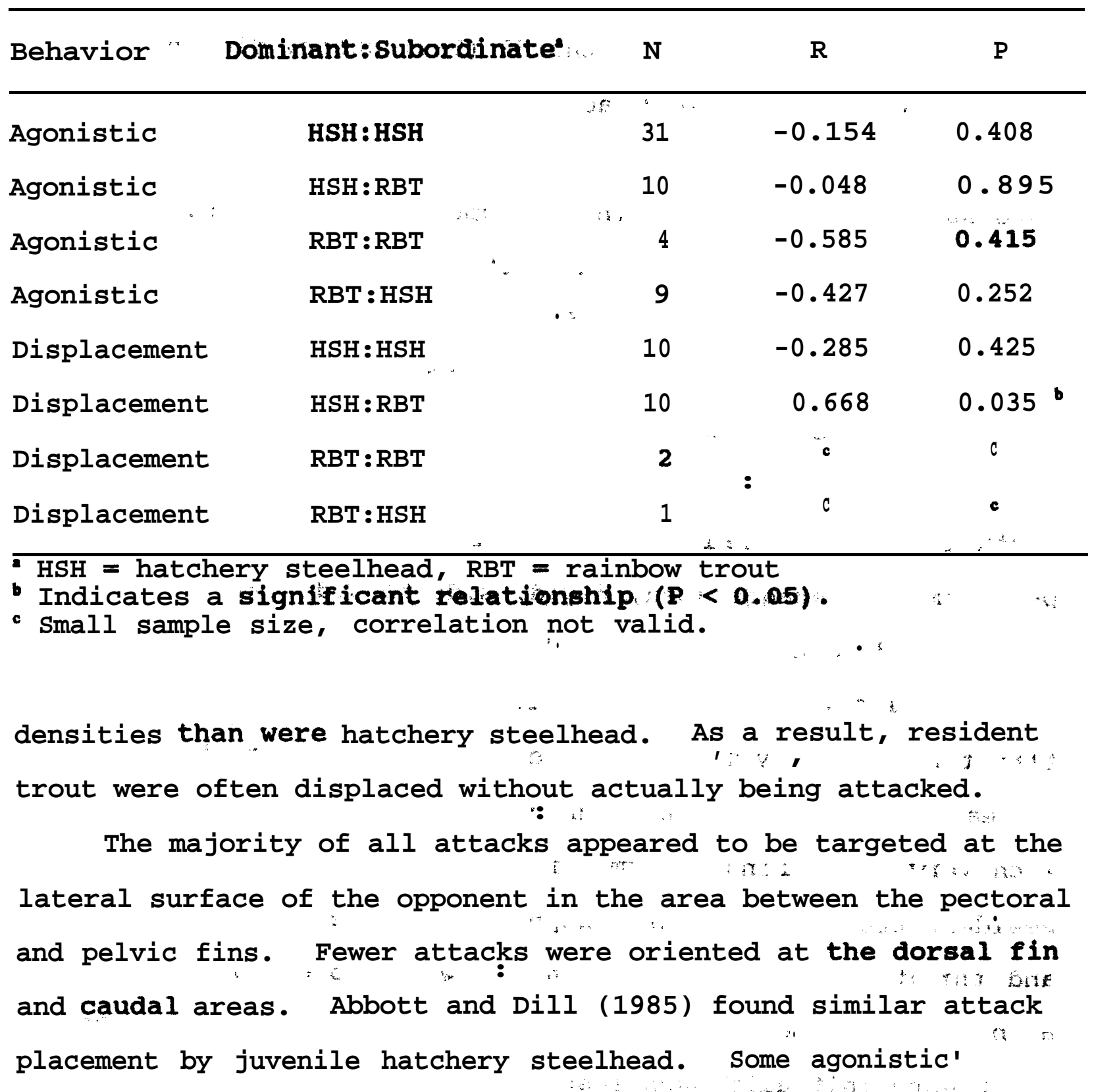


encounters involved reciprocal exchanges wherein two fish chased and'nipped the tail of the othor flah resulting in very tight circular motion. Hatchery steelhead residuals in Iater surveys (July to October) appeared to be less aggresstve, fed wore, and used habitat features in ways similar to resident trout. It is unclear whether this tendency was related to tmproved survival of fish exhibiting certain behavior or to changes in fiah behavior over time (learning or adaptation). More aggress ive attakks (number of agoniatic encounters/fish/minute) - were observed when high densities of fish were present (Way - July) than when densities were low (August - October) These findings are contrary to Jenkins $(1971 ;)$ and $\mathrm{Li}$ and Brooksen (1977) who Bid not find aggression in salmonids to be density dependent. . $y^{*}$, if

As stream temperatures increased and flow decreased in Jungle Creek, an increased incidence of Saprolegnia infection was documented in hatchery steelhead and resident trout in the creek (S. Roberts, WDW; pers, comm.). The incidence of saprolegnia in hatchery steelhead emigrating from Jungle Creek between Hay 29 and June 13 was $13.2 \%(H-53)$. No resident trout showed signs of infection during this period. A sample of ish collected by electrofishing 'in Jungle Creek on June 25 showed an infeotienta rate of 32.18 for- hatchery steelhead $(N=28$ ) and 16.78 for resident trout $(N=6)$. Infected areas on fish were prtmartiy 0 the lateral surface below the dorsal fin. The area infected in corresponded to the area where most fish were attacked during 
agonistic exchanges. Laboratory stream channel experiments using wild brook trout and hatch-y-reared brown trout (Salmo trutta) showed that 33의 of the brook trout contracted saprolegnis and died in the -presence of the brown trout (DeWald and W1lzbach 1992). Brown trout did not contract the infections nor did brook trout in single species trials.

Displacement of resident trout and hatchery steelhead also decreased with time after release, but these decreases were not statistically significant $(P>0.05)$. The only behavior that was significantly co-elated with time was the displacement of resident trout by hatchery steelhead (Table 16). The number of 'resident trout that were displaced by hatchery steelhead per total number of salmonids observed per minute of observation time increased significantly after the hatchery steelhead- smolt releases.

Naturally produced fry (resident trout/steelhead) were first observed on July 26. Correspondingly, the mean size of resident trout decreased. The smaller average size of resident trout after late July may have influenced the outcome (displacement) of agonistic encounters in favor of hatchery steelhead. Though mean length of hatchery steelhead exceeded that of resident trout for the entire study period, the size dffferential increased following-the emergence of age 0 trout. Many researchers studying salmonid competition in streams have noted that large fish usually dominate small fish (Newman 1956; 
Griffith 1972, 1988; Allee 1981; Abbott et al 1985; Heggenean,

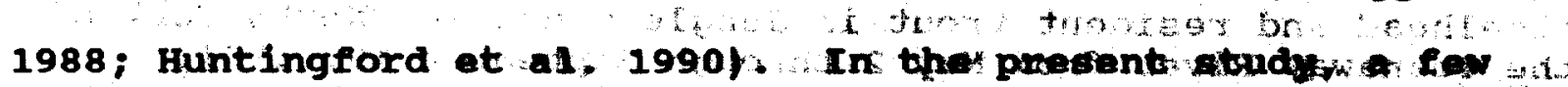
exceptions to this generality occureed, in which emalyer tesidant trout dominated larger hatchery steelhead (Table 17). In allopatric intraspecific contests involving hatohery steelheadia larger fish dominated $75 \%$ of 'the time., and' larger resident 'trout dominated $66 \%$ of their allopatric bouts.

Fausch (1984) and Huntingford et al. (1990) have suggested that fish size may be a consequence, not a cause, of social hierarchy. We were unable to support" or refute 'this hypothesis because we released hatchery steelhead into the system at a larger size than pre-existing resident trout. Therefone, hatchery steelhead did not attain their largen size by dominating social interactions after thes were releasedrolthough larger individuals could have attained a larger size by being dominant during their hatchery rearing experience). Condition factors for hatchery steelhead decreased as time progressed (Table 13). suggesting that these larger fish may not have been profiting. energetically frow thelt size-related abihation;

The potential for competitive interactions to occur between resident trout and hatchery steelhead may be greatest after hatchery steelhead reproduce in the wild. Characteristics of spawning areas and timing for resident trout and naturallyproduced steelhead are being identified by ongoing spawning. surveys (see Baseline Phase, this report). This information will 
Table 17. Size-related dominance relationships between hatchery steelhead and resident trout in Jungle Creek and North Fork of the Teanaway River from May 2: through September: 19, 1991. Number of agonistic occurrences observed (N) and the percentage of contests resulting in the corresponding dominant: subordinate relationship for each combination grouping are shown.

Group Dominant (size):subordinate (size)" N Percent

Sympatric hatchery steelhead and resident trout

$\begin{array}{llll}\text { HSH } & \text { (large): RBT (small) } & 9 & 50.0 \\ \text { HSH (small): RBT (large) } & 1 & 5.6 \\ \text { RBT (large): HSH (small) } & 3 & 16.3 \\ \text { RBT (small): HSH , (large) } & 5 & \ddots & 27.7\end{array}$

Allopatric hatchery steelhead

$\begin{array}{lllll}\text { HSH } & \text { (large): HSH (small) } & 6 & 75.0 \\ \text { HSH (small): HSH (large) } & 2 & 25.0\end{array}$

Allopatric resident trout

$\begin{array}{llll}\text { RBT (large): } & \text { RBT (small) } & 2 & 66.7 \\ \text { RBT (small) : } & \text { RBT (large) } & 1 & 33.3\end{array}$

- $\mathrm{HSH}=$ hatchery steelhead, RBP = resident trout

be valuable in predicting emergence timing of the progeny of resident trout and steelhead. It has been shown that groups of sympatric 'stream salmonids that emerge earlier than their competitors have a size advantage that confers a competitive 
advantage in obtaining resources (e.g. food and/or habitat) that may Iimft production (Griffith 1972, i988, Chandzet and Bjomn: 1988). Preliminary spawn tining data for resident trout and steelhead in the upper Yaktua bäin suggests that pubstantialc: overlap occurs.

Underwater abservers were not able to identify resourca (e.g. food or space) that hatchery fish may have been competing for. It appeared that hatchery figh were aggresbive and expended a great deal of energy, resulting in no apparent gain in terms of better access to food or habitat. The bioenergetic costs assoclated with this behavior are great. These behaviors can have a genet 1c component and may also be influenced by rearing experience.

\section{Fish Abundance Relationship\& over Time}

Underwater observations of hatchery steelhead and resident

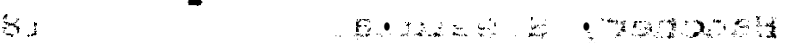
trout in index areas provided information on population abundance trends over time. The number of hatchery steelhead observed per minute decreased after time of release whereas the number of minute decreased after time of release whereas the number of rainbow trout increased slightly (Table 18, Figure 17). The increase in resident trout observations was primarily due to the occurrence of age 0 (those estimated to be less than $100 \mathrm{~mm}$ long) rainbow trout begin\&g on July 26. It is unclear whether the

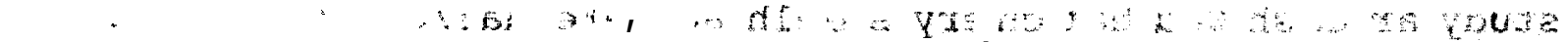
number of trout observed may also have increased due to immigration of resident trout from outside the study area 
following the overall decrease in abundance of -hatchery steelhead. Most hatchery steelhead (64\%) emigrated from the . North Fork system during the typical smolt outmigration period, However, large concentrations of hatchery steelhead were observed in the river into late summer (e.g. 19 hatchery steelhead were observed in one site on July 26). This decrease in relative abundance of hatchery steelhead may be accounted fot by several factors, including: mortality, harvest by anglers, emigration to areas downstream, or a combination of the aforementioned..

Table 18. Correlations between fish observation rate (number/minute) and number of days after hatchery steelhead release for hatchery steelhead and resident trout in the North Fork of the Teanaway system from May -through October, 1991. Number of sample periods (N), correlation coefficients (R), and probability values (P) are shown.

\begin{tabular}{lcccc}
\hline Group & $\mathbf{N}$ & $\mathbf{R}$ & $\mathbf{P}$ \\
\hline Hatchery Steelhead & 18 & -0.617 & $0.005^{\prime}$ \\
Resident Trout (all sizes) & 20 & 0.662 & $\mathbf{0 . 0 0 1}$ \\
Resident trout $(\geq 100 \mathrm{~mm})$ & $\mathbf{2 0}$ & 0.259 & $\mathbf{0 . 2 5 7}$ \\
Indicates statistically significant correlation (P < 0.005$).$
\end{tabular}

\section{Creel Survev}

Results from the limited creel survey conducted in the study area showed hatchery steelhead were harvested at high rates. Seventy-five anglers were contacted between June 1 


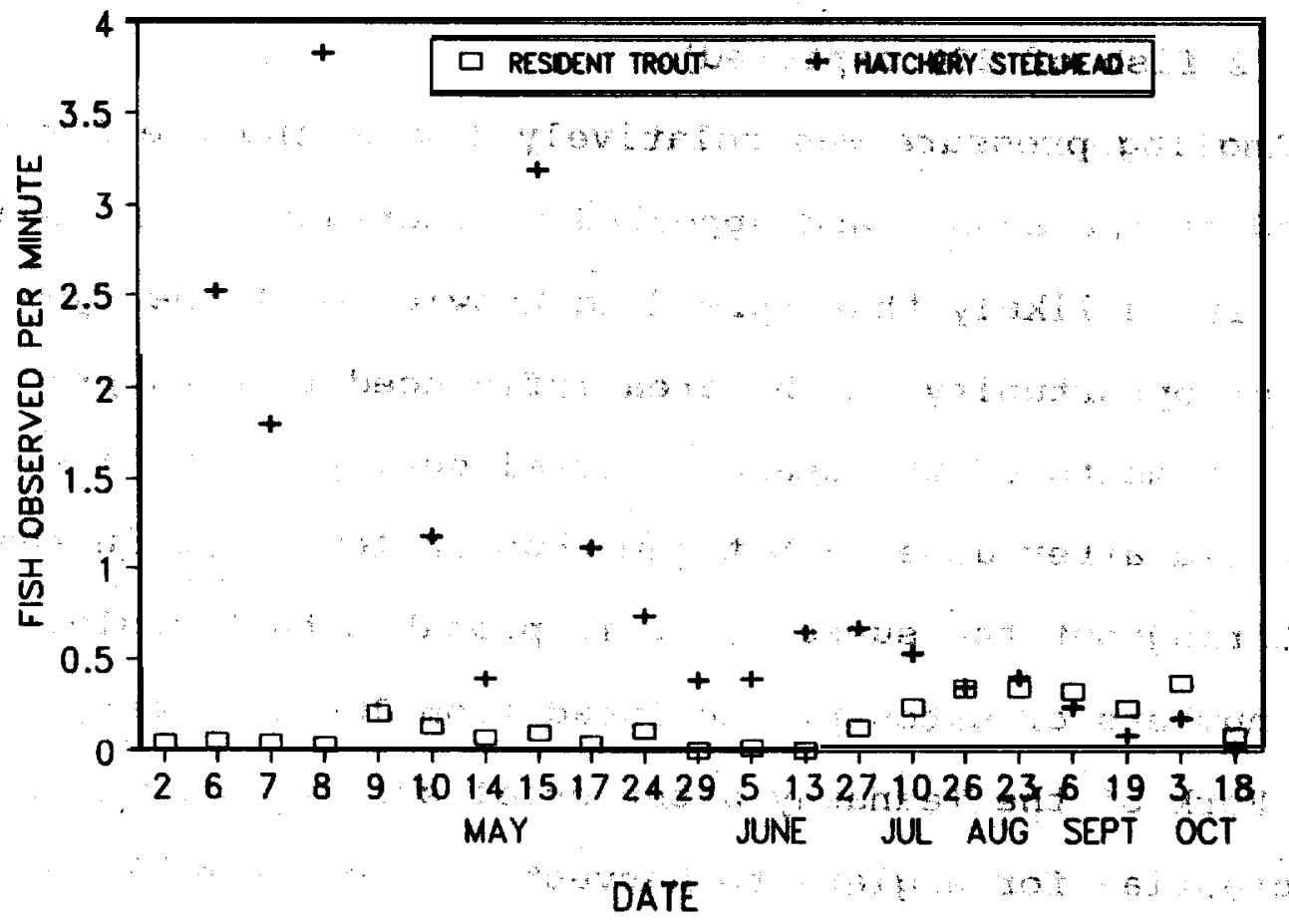

Figure 17. Number of $\mathrm{fish}$ observed per minute by snorkelers in Jungle Creek and the North Fork of the Teanaway River between May 2 and October 18, 1991.

(opening day) and June 13. Anglers surveyed spent a tatal Qf 158

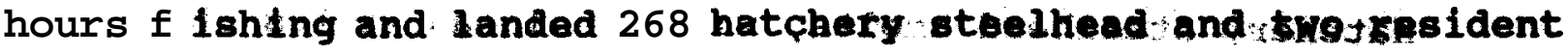
trout. The wan catch rate duribghis pestiod vas 4.08 fthh/h. Anglers were observed selectively retaining tha laxgew bet

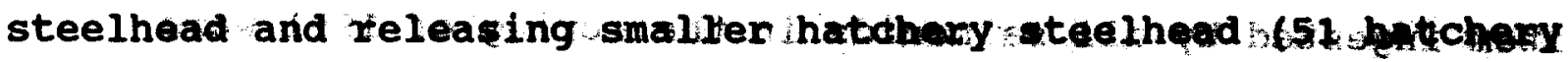
stee thead (19\%) of the 268 caughternere ireleased) Hany anglere reported catching their limit of sight fish in less than one. 
hour. From the limited angling data we collected it appears that the initial impact on wild fish in the study area was relatively minor (2 fish of 270 captured).

Angling pressure was relatively low during the first weekend of the season and appeared to increase after about a week. It is likely that spreading knowledge of the 'good fishing' opportunity in the area influenced fishing pressure over the first month of the season. Creel survey activities were terminated after June 13 but numerous anglers were in the study area throughout the summer. It is probable that anglers removed large numbers of hatchery steelhead from Jungle Creek and the North Fork of the Teanaway after creel survey activities ended. The potential for anglers to harvest hatchery steelhead smolts as "trout" is great in the Teanaway system and other areas where releases are proposed per the YFP if emigration rates and residualism tendencies were similar to those observed in this study.

\section{Food Utilization}

Hatchery steelhead smolts, wild steelhead smolts and. resident trout ate similar food items during the pring of 1991 (S. Urakawa and P. James, CWU, pers. comm.). The primary food item ingested by all salmonids in the spring of 1991 were earthworms (Figures 18, 19, and 20): Wild and hatchery steelhead ingested more types of food items than did resident trout.. The 
- largest difference between the hatchery and wild steelhead is that hatchery steelhead ingested more debris (nonnutritious material such as, pine needles, sticks, and burned wood) and more earthworms than wild steelhead or resident trout. Snorkelers were able to observe wild figh and hatchery fish feeding on many occasions throughout the foryy fedson. Some hatchery fish appeared to ingest drift items whin hours following release. Snorkelers noted a greater tendend for hatchery fish to ingest drift items of all kinds whereas whtalde appeared to be more selective. Wild fish would move to intercept many pieces of debris only to turn away from them prior to actual ingestion. Hatchery fish rarely rejected drlftitems during the first few weeks after release. This behavior was less noticeable later in the summer when residualized hatchery steelhead seemed to feed more like wild trout.

These food utilization data are preliminary and incomplete. Other aspects of their work includes determination of food availability and these activities should continge through $19 \mathrm{gs}$. Data will be analyzed nore fully by unakawa and Jamegand and report of findings will be produced. 


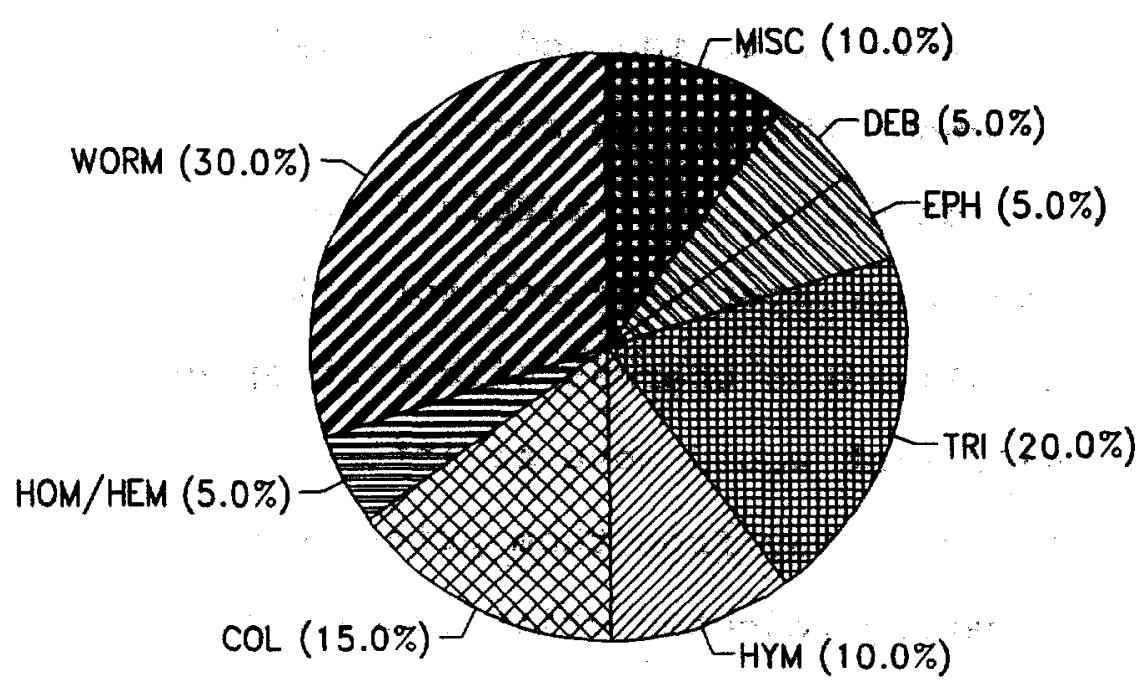

Figure 18. Percent by volume of various food items consumed by resident trout captured in the North Fork of the Teanaway River during the spring of 1991. MISC = unidentified items, $\mathrm{DEB}=$ debris, $\mathbf{E P H}=$ Ephemeroptera (mayflies), PLE = Plecoptera (stoneflies), TRI = Tricoptera (caddisflies), HYM = Hymenoptera (ants and bees), COL = Coleoptera (beetles), HFH/HOM = Hemiptera (true bugs) /Homoptera (leaf hoppers), WORM = Oligochaetes (earthworms). (data from S. Urakawa, CWU, pers. comm.). 


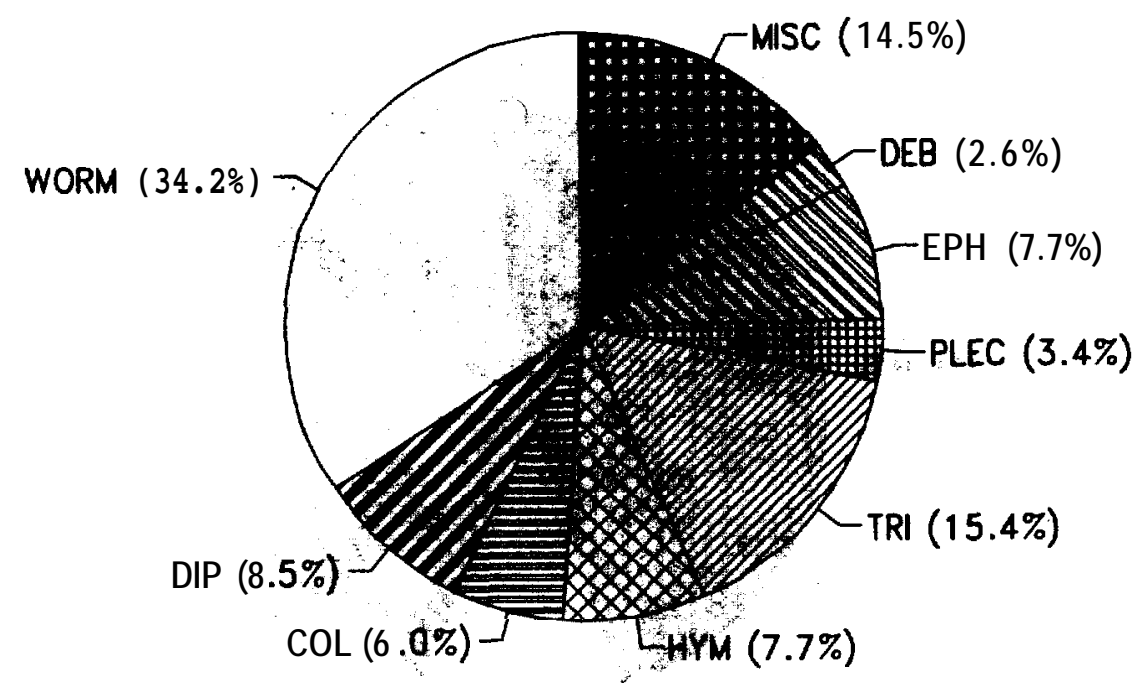

Figure 19. Percent by volume of various food itema conmmedy wild steelhead daptured in the North Fork of the reanavy 1 ivex during the spring of 1991. IISC untdentified iteme o DWBdebris, EPH - Ephemeroptera (mayties), PLR (Rlecopteralyda

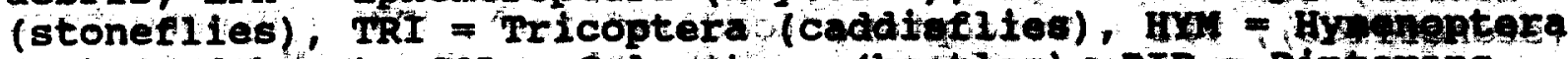
(ants and bees), col = coleoptera (bedtles) anI - Diptesang (mlages), worM - oligodhaetes (earthworms) ( (Data from 6 . Urakawa, CWU, pers. comm.). 


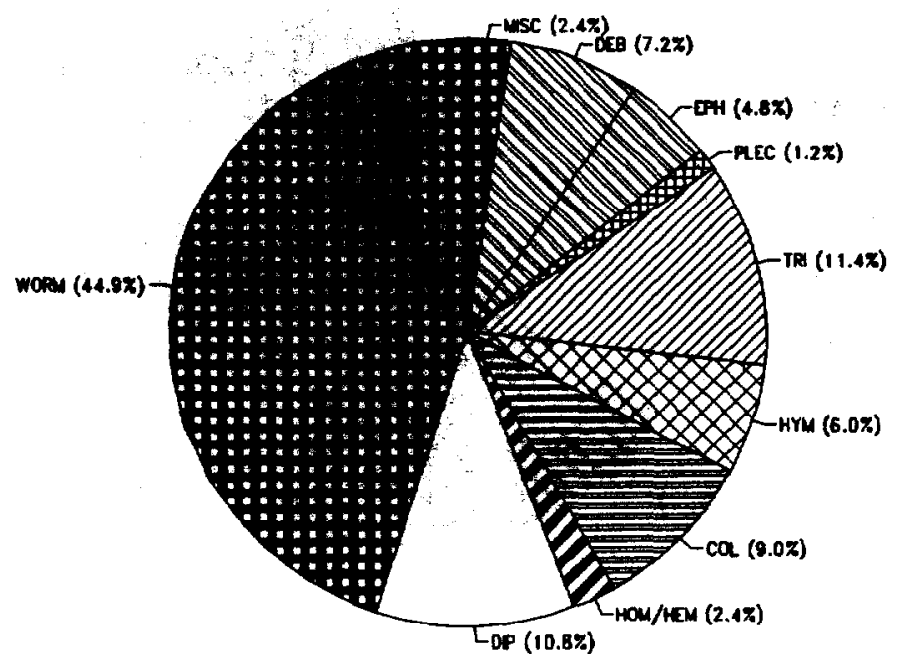

Figure 20. Percent by volume of various food items consumed by hatchery steelhead captured in the North Fork of the Teanaway River during the spring of 1991. MISC = unidentified items, DEB = debris, EPH = Ephemeroptera (mayflies), PLE = Plecoptera (stoneflies), TRI = Tricoptera (caddisflies), HY = Hymenoptera (ants and bees), COL = Coleoptera (beetles), HEM/HOH = Hemiptera (true bugs) /Homoptera (leaf hoppers), DIP = Dipterans (midges), WORM = Oligochaetes (earthworms). (Data from S. Urakawa, ChU, : pers. comm.). 


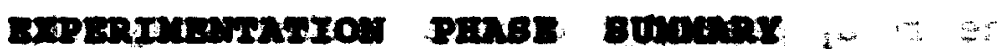

h great deal was learned about the potentad techanisms involved in competitive interaction8 and, under exieting conditions of the study, it appeared that competition was occurring. However, after orly one year of thit multi-year effort it is not possible to daw any firw onclustons. It remains unclear what the outcome of these Interactions uere on variables such as growth and survival of resident trout.

Some of the results of these studies that auggest hatchery steelhead could negatively influence the resident tront populations in the North Fork of the Teanaway were:

- Large numbers of hatchery steelhead did not migrate out of the North Fork prior to June $1,6,4$ 0 4

- Residual hatchery steelhead physicaly dipaced fuventle residant trout through late summer:

- Many residual hatchery sted lhead makedsuere round to by

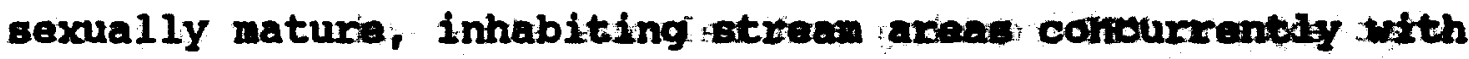
smaller resident rainbow and cutthroat trout reammado

- Aggreseive behavior exhibitda by the hatchtary staditidit may have led to the Increased incldence of disease ifn hatchery and wild fish in the release atrean 
- There appeared to be a relatively high degree of overlap in food items ingested by hatchery and wild steelhead smolts in the North Fork.

o The residual hatchery steelhead dispersed throughout the North Fork drainage well upstream into known cutthroat and bull trout habitat.

One of the reasons for releasing hatchery fish as smolts (as opposed to fry) is to minimize the potential for negative impacts on pre-existing fish populations; under the assumption that the smolts will migrate out of the area rapidly and will negligibly influence local fishes. Bcological problems may arise, however, when the smolts that are released do not all rapidly emigrate from the system. Currently proposed YFP rearing and release strategies involve transport of pre-smolts from hatchery facilities to acclimation ponds for a period of weeks or months, prior to exiting these ponds of their own volition when physiological readiness dictates, It is. unknown atthis time to what extent YFP rearing and release strategies will produce fish ready to outmigrate.

Plans for continuation of this research include the addition of the adjacent Middle Fork of the Teanaway River as an unsupplemented control stream. Population estimates, optmigrant trapping, and underwater behavioral observations will be: 
conducted in both streams. Thesestudies will improve knowledge available to monitor and assess the impacts of releases of hatcher; steelhead on resldent trout abundance, site, growth, and behavior.

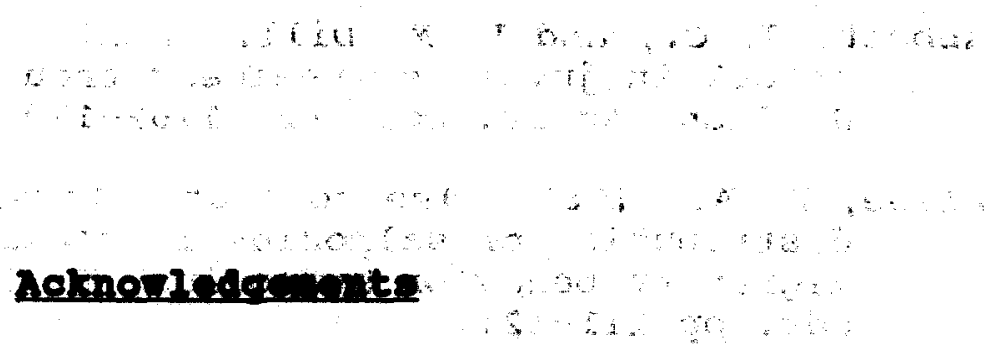

We received assistance from many people during the otudy perlod. The nameroure anglers and angling groups who alpported us with volunteer field help and Information on tagged ich they captured via hook and 1 ine are greatly apprealated Jin Cumins, Eric Anderton, Iim Lee, Tim tuwe, Pat mulett, and Chr 1 e wagemann, along with many other people of mble provlded raluable asistance. Thanks to Joel Hubble, Mark Johnston, Hke Xohn, B121 Shat, Tom Scribner, and Dave Fast of the Yakima Indian Nation Fisheries prograt who furnished informetion, deta, peroonnel cupport; and

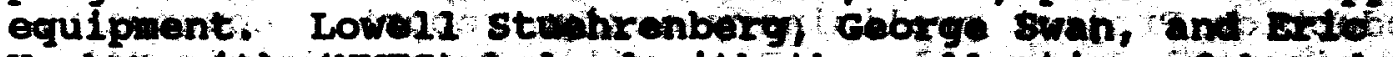

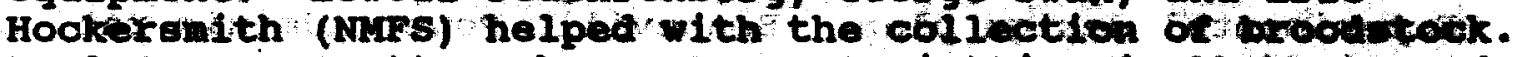
Paul James, Scott Urakawa, Terry DeViett1, Jim Thowoh, wind the staff of the Biological sciences Department at Central washington University contributed time and expeptsed podd poaredituandos

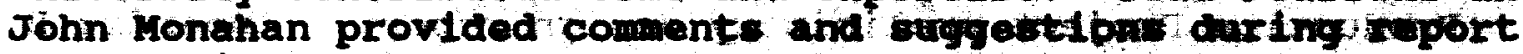
preparation.

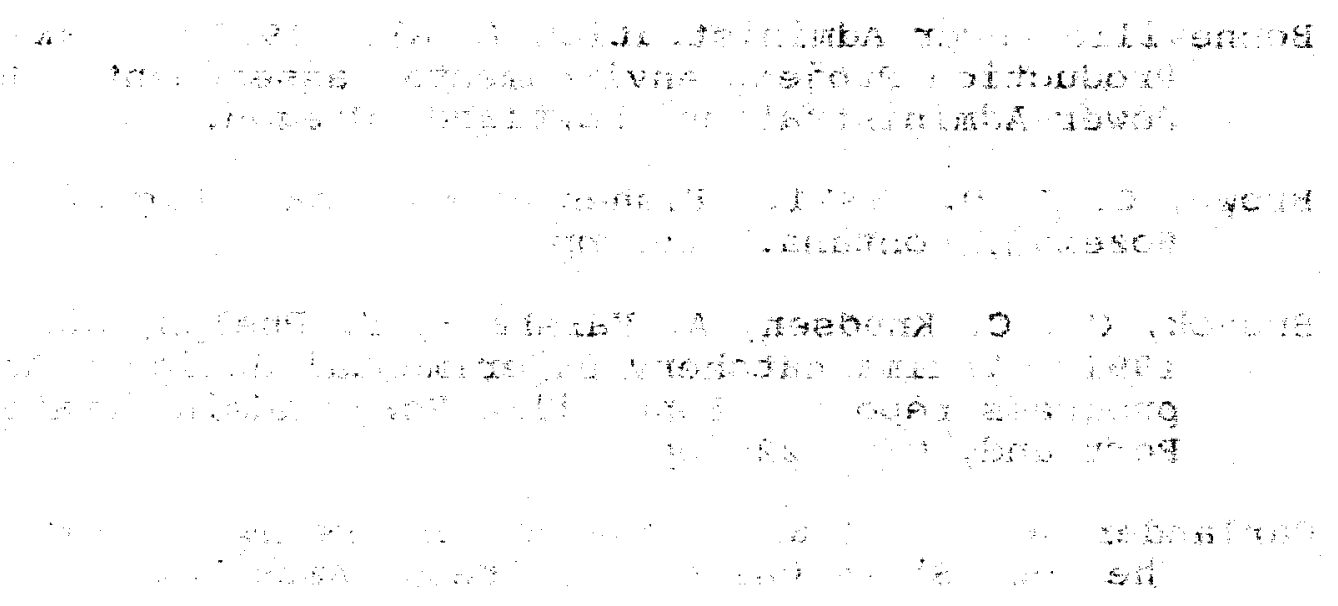

Pef 


\section{Reforences}

Abbott, J. C., R. I. Dunbrack, and C.D.Orr. 1985. The - interaction of size and experience in dominance relationships of juvenile steelhead trout (Salmo gairdneri). Behavior 92: 241-253.

Abbott, J. C., and L. M. Dill. 1985. Patterns of aggressive attack in juvenile steelhead trout (Salmo gairdneri). Can. J. Fish. Aquat. Sci. 42: 1702-1706.

Allee, B. A. 1981. The role of interspecific competition in the distribution of salmonids in streams. in Salmon and trout migratory behavior symposium, E. I. Brannon and E. 0. Salo, eds. pp 111-121.

Bisson, P. A., J. I. Neilson, R. A. Palmason, and L. E, Grove. - 19.8.2. A system of naming-habitat types in small streams, with examples of habitat utilization by salmonids during

low streamflow. In N. B. Armantrout (ed.), Acquisition and utilization of aquatic habitat inventory information. Proceedings of a sympostum, 28-30 October 1981, Portland, Oregon. American Fisheries Society.

Bonneville Power Administration (SPA). 1990a. Yakimark1ickitat Production Project preliminary design report. Appendix A: Experimental design plan. Bonnevilie Power Administration, Portland, Or.

Bonneville Power Administration (BPA), 1990b Yakima/kifckitat Production Project preliminary design report. Appendix B: Water supply analysis. Bonneville Power Administration, Portland, Oregon.

Bonneville Power Administration (BPA). 1990c. Yakima/klickitat Production Project environmental assessment. Bonneville Power Administration, Portland, Oregon.

Brown, C. J. D. 1971. Fishes of Montana. Big Sky Books, Bozeman, Montana. 207 pp.

Busack, C., C. Knudsen, A. Marshall, S. Phelps, and D. Seiler. 1991. Yakima hatchery experimental design. Annual progress report. Bonneville Power Administration, Portland, OR. 226 pp.

Carlander, K. D. 1969. Handbook of Freshwater Fishery Biology. The Iowa State University Press, Ames Iowa. vol. 1. 


$$
\text { An as as }
$$

Chandler, G. L. and T, C.,Byornnd 1988, Abandano, prowth, and

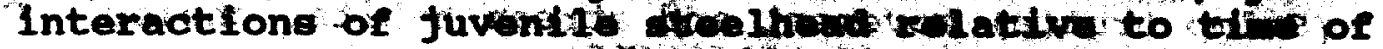

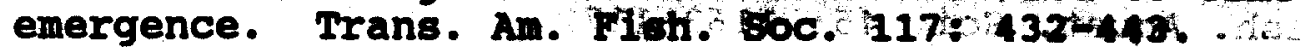

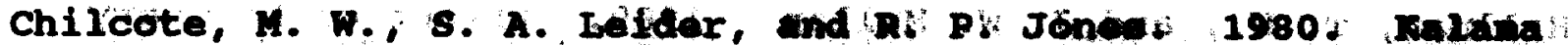

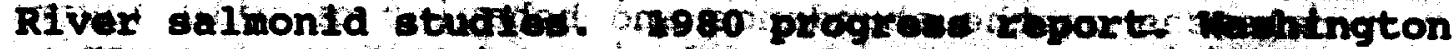

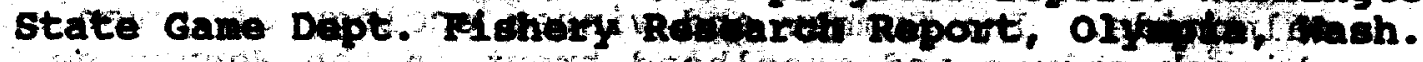

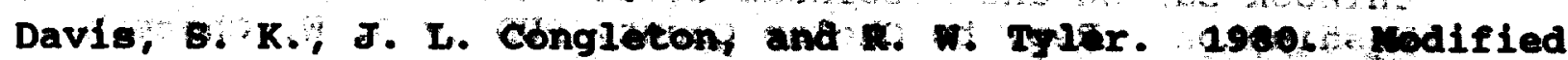
fyke net for the capture and retention of salwoingurts in large rivers. Prog. Fish Cult. 42(4): 235-237.

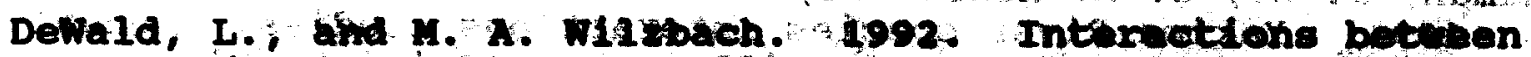
native brook trout and hatchory brope trouts zeteete on habitat use, feeding, and growth. Trahs f Am, Efah, soc. $121: 287-296$.

Fast, D. E., F. D. Hubble, and D D. Watson, 1988, yatera River spring ekinook enhancentent titudy. Annuan seport 1967. Yakima Indian Nation, Toppenish, Washington. I01 pp.

Pausch, R. D. 1984. Pronttable atrea positions corTsalmonids: relating epecific grouth rate to not ondrgy gailw. ean. J. Zool. 62 : 441-451.

Fleming, I. A., and M. R. Grose 1992. Reproductive behavios of

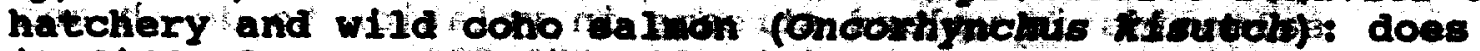
it differ? Aquadultute 103:101-121. $t$ t $3.6 \mathrm{~b}: \mathrm{i}$ ?

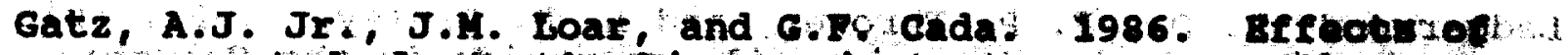

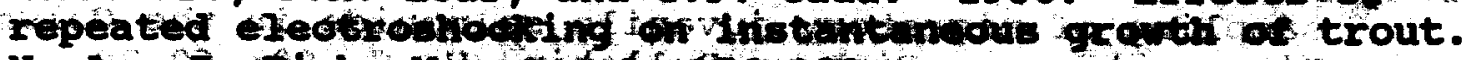

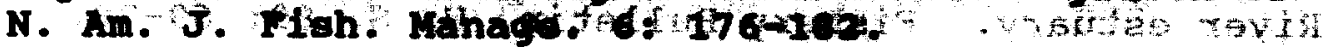

soldstein, R. H. 1978. Quantitative congarison of seining and

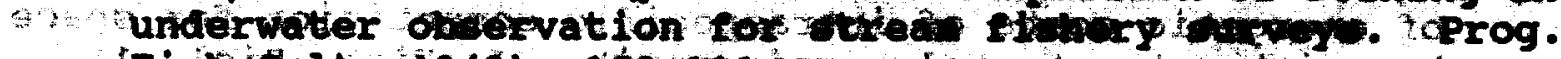

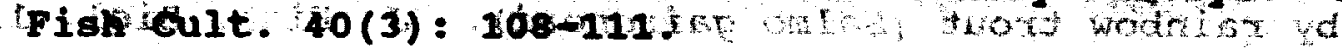

Griffith, J. S. 1972. Comparative behavior and habltat

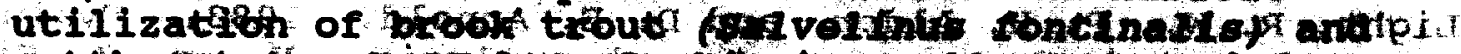

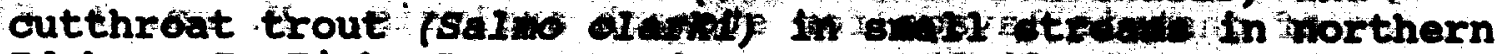
Idaho. J. Fish. Res. Board. Can. 29*265-273,

Griffith, J. Sy, 1988. Review of conpetition. Bdevean culthreat

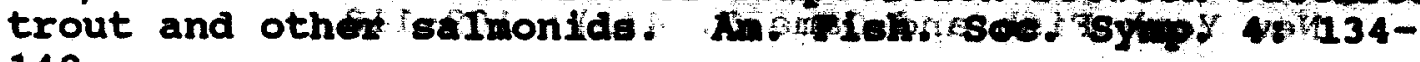
140.

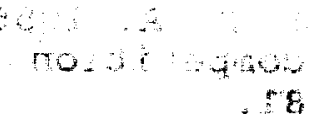


Heggenes, J. 1988. Effect of experimentally increased intraspecifia competition $\rho$ endentary adult brown trout . " (Salmo trutta) movement and atream habitat choice. Can. J. Fish. Aquat. Sci: 45:-1163-1172.,

Hillman, T.W., and J. W. Mullan. 1989. Effect of hatchery releases on the abundance and bohayior of wild juyenile salmonids. In: summer andwinter ecology of juvenilfe chinook salmon and steelhead trout in the Wenatchee River, Washington. Rep. to Chelan County PUD by D: W. Chapman consultants, Bo se, ID. 379 pp.

Hindman, J. N., G. A. MoMichael, J. P. \&son, and S. A. Leider. 1991. Yakima River species interactions stydies. Annyali report for DY 1990. Bonneville Power Adminietration, Portland, . OR. 75 pp.

Huntingford, F. A., N. B. Metcalfe, J. E. Thorpe, W.D. Graham, and C. E. Adams. 1990. Social dominance and body. size in Atlantic salmon parr, Salmo salar Is. J. Fioh. Bial. 36 : 877-881.

Jenkins, T.:M., Jr. 1971. Role of segial behavior in diapergal of introduced rainbow trout (salmo gaindnexi) J. Ish. Res. Board Can. 28: 1019-1027.

Kennedy, G. J. A., and C. D. Strange. 1982. The distribution of salmonids in upland streama in relation to depth and gradient. J. Fish Biol. 20: 579-591.

Ledgerwood, R. D., F. P. Thrower, and F. M. Dawley, 1991. Piel sampling of migratory juvenileratimonida in the calumbia River estuary. Fi ghery Bulletipur. U, $S$ 89: 69-78.

Li. H. W., and R. W. Brockeen. 1977. Approaches to the analyeis of energetic costs of intraspecific competition for fopace by rainbow trout (Salmo gairanert). J. Rish. Bigl. 11: 329-341.

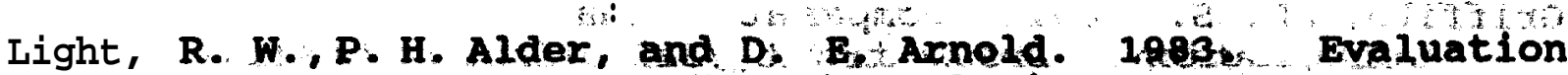
of gastric lavage for atsmach analysis. N. An. J. Fish. Manage. 3: 81-85.

Loeb, H. A. 1957. Night collection of fieh with electrieftyy. New York Fish and Gamen. 4(1): 109-118,

Newman, M.A. 1956. Social behavior and interspecific competition in two trout species. Physiol. 2001. 29: 6481. 
Northwest Power Planning Coune1l (NPPC). 1987. Columbia River Basin fish and wildlife program. Northwest Power Planning Council, Portland, Or. 246 pn.

Piper, R. G., I. B. McElwain, L. E. Orme, J. P. Mccraren, I. G. Fowler, and J. R. Leonard. 1983. Fish hatchery management. U.S. Dept of the Interior, Fish and Vildilfe Serv. Washington, D.C. 517 pp.

Schill, D. J., and J. S. Griffith. 1984. use of underwatex observations to estimate cutthroat trout abundance in the Yellowstone River: N. Am. J. Fish Manage 4: 479-487.

strange, C. D., M. W. Aprahamianf and A, J. Minttone. 1989. Assessment of a semi-quantitative electrte lishing sanpling technique for juvenile Atlantic salmon; salmo calar i, and trout, salmo trutta L., in small streases Aquacult. and Fish. Manage. 20: 485-492.

Taylor, E. B., and P. A. Larkin. 1986. Current response and agonistic behavior in newly-emerged fry of chinook salmon, oncorhynchus tshawytscha, from ocean- and stream-typo populations. Can. J. Fish. Aquat. Sci. 13:565-573.

Tyler, R: w. 1979. Method of ampling seawaxd migrations of juvenile salmon,. Prog. Rish cult $41(2)$ 78-81,

Van Deventer, J. S., and W.S. Platte. 1905. A oonguter software system for entering, managiag and anaiyding ifh capture data from streams. USDA Forest service Research Note INT-352. Intermountain Research Station, Ogden, . Utah. $12 \mathrm{pp}$.

Vincent, E. R. 1971. River eleotrofiebing and fiah population estimates. Prog. Fish Cult. $33(a)$, $169-169$ t

ztppin, C. 1958. The removal mathod of population estiveten J. Mildl. Manage. $22(1): 82-90$.

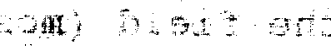

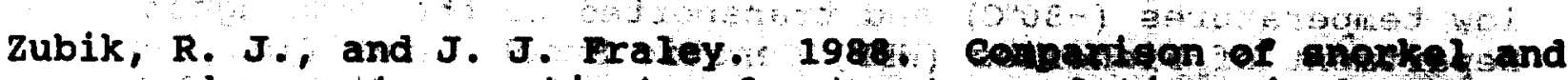
mark-recapture estinates for trout pepulatiphs in $10 \mathrm{rg}$ t streams. N. An. J. Fish. Hanage, 6 : 58-62. 


\section{Appendix A}

Patterns of Genetic Diversity in Yakima River Rainbow Trout: Initial analysis of 1990 and spring 1991 collections

by Stevan R. Phelps

Washington Department of Fisheries

\section{INTRODUCTION}

The electrophoretic analysis of rainbow trout, oncorhynchns mvkiss, collected from the mainstem Yakima River and tributaries above Roza Dam 'is part of the baseline phase of the Yakima River species interactions studies. The-purpose of this work waS provide a baseline genetic profile of wild-spawned rainbow trout populations, to determine the patterns of genetic diversity and stock structure among these populations, and identify differences between these populations and steelhead and hatchery rainbow trout strains.

Past work on Yakima River rainbow trout by Campton and Jabnson (1985) indicated that the fish were'an admixture of hatchery and wild rainbow trout gene pools. The authors concluded that the population was unlike, hatchery steelhead. In this study, we, examined some of the same locations as Campton and Johnson

(1985) . After we examine the yearly, and spring and fall sample diversity within a collection location;, we will compare our data to the past electropharetic work in the Yakima River.

\section{METHODS}

Rainbow trout were collected from seven mainstem locations in the Yakima River and nine tributaries-above-.Roza Dam during the spring and fall of 1990, and the spring of 1991 (Table 1 and Hindman et al, 1991) . The collected fish were either dissected in the field (most adult collections) or frozen whole at ultralow temperatures $\left(-80^{\circ} \mathrm{C}\right)$ and transported to the Washington Department of Fisheries (WDF) Genetic stock Identification Laboratory. Muscle, heart, eye and liver were dissected from each juvenile and placed into $12 \times 75 \mathrm{~mm}$ test tubes: Total length, weight, and 12 scales from the preferred area were taken. The smolts were photographed and refrozen for storage. Cutthroat trout and obvious hatchery rainbow trout were excluded from the collections. We combined spring 1990 and 1991 collections from each location because of the small number of samples collected in 
spring 1990.

Electrophoresis followed the methods of Aebersold et al. (1987). The electrophoretic protocol, enzymes screened, and allelea observed during this study (and other studies on rainbow trout and steelhead by WDF) are listed in Busack at al. (1991) Genetic nomenclature follows the conventions of shaklee at al (1990)., BIOSYS-1 (SWOfford and' selander 1981) was ueed for the statistical analysis of the electrophoretic data.

\section{RESULTS and DISCUSSION}

This analysis was based on the products of 43 loci. Three 100i were monomorphic, maH-2*, mAH-4*, TPI-2* (other monomorphdc logi were excluded from the analysis). Allele frequencies for all loci are available from wDN upoin request. The averagesn: . heterozygosity and percentage of polymorphic loci are slightily higher than past studies due to the exciusion of monomorphlo Ioci from this analysis. However, the values are useful for , ${ }^{\prime}, 4$ comparisons among the populations in this study (Table 2). The highest percentage of polymorphic loci occums in the unternum 1 spring 91, swauk fall 90, and in the lomer Yakina RIver salnatiom collections. The wDit hatchery rainbow trout etrains had the lowest values. In contrast, the average haterozygasit fes were similar between the wild and hatchery collections. - $z^{*}$

Genetic alferences within collections

The nonduplicated loci were teated for agreement to fandyWelmberg equilibrim expectations (duplifoated implock oninots be tested because we cannot tell how the genetichtantation tonth partitioned among the two loci) (Table 3). The most common type

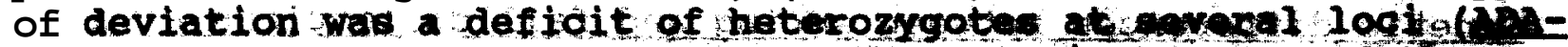

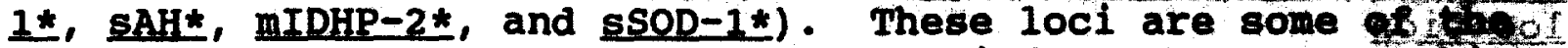
loci that have large allele frequency differences anong Yakina

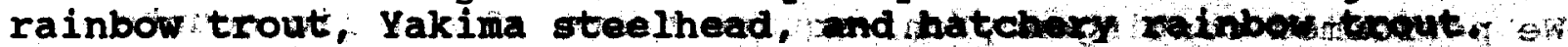

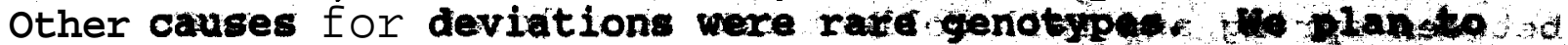

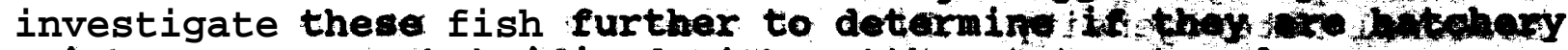
ralnbow trout or hybridized with cuttrirat trout and wes included in the sample inadvertentity. th

$$
\text { at: ar: = }
$$

We had enough samples from Umtanum Creek to testropring 2990 va.

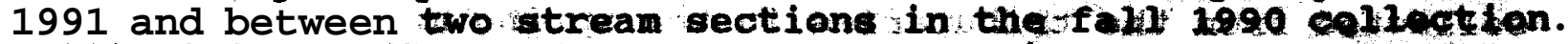

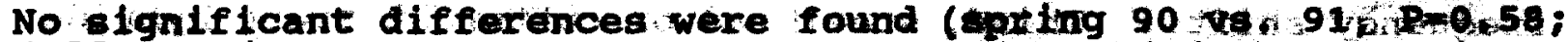
fall section 1 vs. section $2, p=0.16$ ) In addition, no lopi vere out of Hardy-Weinberg expectations (Table 3) so we combined the spring samples into one collection and combined the two areas 
from the fall 1990 sampling into one collection for genetic analysis.

\section{Genetic differences amona colleations}

We calculated two measures of genetic distance and performed cluster analysis using unweighted pair group method. The coefficients used were the modified Rogers distance (Wright 1978) and Cavalli-sforza \&dwards (1967) chord distance.:

We identified three major groups of rainbow trout in the Yakima River above Roza (Figure 1). The first group consists of Yakima mainstem collections $1-5$ and the tributaries below Ellensburg Dam. The Manastash Creek collections from this area, however, group more closely with other tributaries. The Badger creek collection is an outlier.

The second group consists of collections from the uppermost tributaries and mainstem section of the Yakima River. The Big. Creek collection- is in this group even though it flows into the Yakima mainstem section 6 .

The third group is mainly the tributary collections between Ellensburg Dam and Cle Elum. These populations are distinct from nearby mainstem areas and it appears that- there is not much:' genetic exchange between the mainstem and these tributaries ... Yakima mainstem collections $1-5$.

None of the groups are very similar to WDW hatchery strains. One possible exception to this is the Badger Creek collection. Using another measure of genetic relationships (Figure 2), the Badger Creek collection is associated-with the Spokane and south pacoma Hatchery collections.

Genetic differences between spring and fall collections at a $"$ location

We performed contingency chi-square tests of allelic counts between spring and fall collections at a location to tent for seasonal heterogeneity. Five of nine tests were significant at the 0.05 level. We have identified several possible causes for this number of significant differences. First, rainbow trout from hatchery plants may not be distinguished readily during the fall collections because of size. Second, malnstem apannex 'collected from the tributaries in the spring may cause aliela' frequency shifts. Third, steelhead or cutthroat trout hybids may not be as recognizable in fall collections. 
For example, the Wilson Creek fall 90 collection is more Imilar to WDW hatchery rainbow trout at ADA-1*, SAH*, \&AT*, MIDHP-2*,

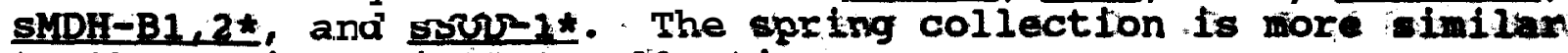
to the Yakima mainstem collections:

Another example is the spring and fall collections from the forks of the Teanaway River. At SSOD-1* the three fall collections contain a higher frequency of the 38 allele an allele that is found at moderate frequencies $(0.03$ to 0.16$)$ in Yakima cteelhead collections. Perhaps some juvenile steelhead-here collected in the fall samples.

SSOD-1 138 allele frequencies between fall and spring Teanaway River collections:

Location

Middle Fork

North Fork- "

West Fork

\begin{tabular}{ll} 
Fall & $\begin{array}{l}\text { Frequency } \\
\text { Spring }\end{array}$ \\
\hline 0.030 & 0.000 \\
0.040 & 0.000 \\
0.080 & 0.030
\end{tabular}

Native vs nonnative cene pools at locations

Numerous allele frequency differences exist between the WW hatchery rainbow trout strains and Yakimä River collections

(Table 4). In general, the collections that comprise the first dendrogram group, Yakima mainstem and Iower tributarfes appare to have the greatest proportion of hatchery rainbow tront gehes. The Manastash, Swauk, Taneum, and Teanaway tributaries appear to have been least affected by past hatchery stocking. There must not be much gene-flow from the' adfacent mainstem tributary sections or recruitment into the mainstem from these four

tributaries. A comparisonof the genetic distances over all loci also indicates greater similarity of mainstem and lower tributaries to the WDW hatchery strains than the upper tributaries.

\section{CONCLUSIONS}

Significant- genetic aiversity exists in rainbow trout in the Yakima River above Rozh Dam, This diversity appears to due to natural stock structure and the result of interbreeding with stocked hatchery rainbow trout. Analysis of fall 1991 and spring 1992 collections should help further define Yakima rainbow trout stock structure. 
Aebersold, P. B., G. A. Winans, D. J. Teel, G. B. Milner, and F. M. Utter. 1987. Manual for starch gel electrophoresis: a method for the detection of genetic variation. NOAA Technical Report NMFS 61, 19 .

Busack, C., C. Knudsen, A. Marshall, S. Phelps, and D. Seiler. 1991. Yakima hatchery experimental design. Annual Report FY 1990 to Bonneville Power Administration, P.O. Box 3621, Portland, OR 97208.

Campton, D. E. and J. M. Johnson. 1985. Electrophoretic evidence for a genetic admixture of native and non-native trout in the Yakima River, Washington. Trans. Amer. Fish. Soc. 114:782-793.

Cavalli-Sforza, I. I. and A. W. F. Edwards. 1967. Phylogenetic analysis: models and estimation procedures. Evolution $21: 550-570$.

Hindman, J. N., G. A. McMichael, J. P. Olson, and S. A. Leider. 1991. Yakima River species interactions studies. Annual Report FY 1990 to Bonneville Power Administration, P.O. Box 3621, Portland, OR 97208.

Nei, M. 1978. Estimation of average heterozygosity and genetic distance from small number of individuals. Genetics 89:583590 .

Shaklee, J. B., F. W. Allendorf, D. C. Morizot, and G. S. Whitt. 1990. Gene nomenclature for protein-coding loci in fish.

Trans. Amer. Fish. Soc. 119:2-15.

Swofford, D. L., and R. B. Selander. 1981. BIOSYS-1: a FORTRAN program for the comprehensive analysis of electrophoretic data in population genetics and systematics. J. Hered. 72:281-283.

Wright, S. 1978. Evolution and the genetics of populations, vol. 4. Variability within and among natural populations. University of Chicago Press, Chicago. 
Table 1. Location and number of rainbow trout collected for electrophoretic and scale patterin analysis from the Yakima River in 1990 and spring, 1991.

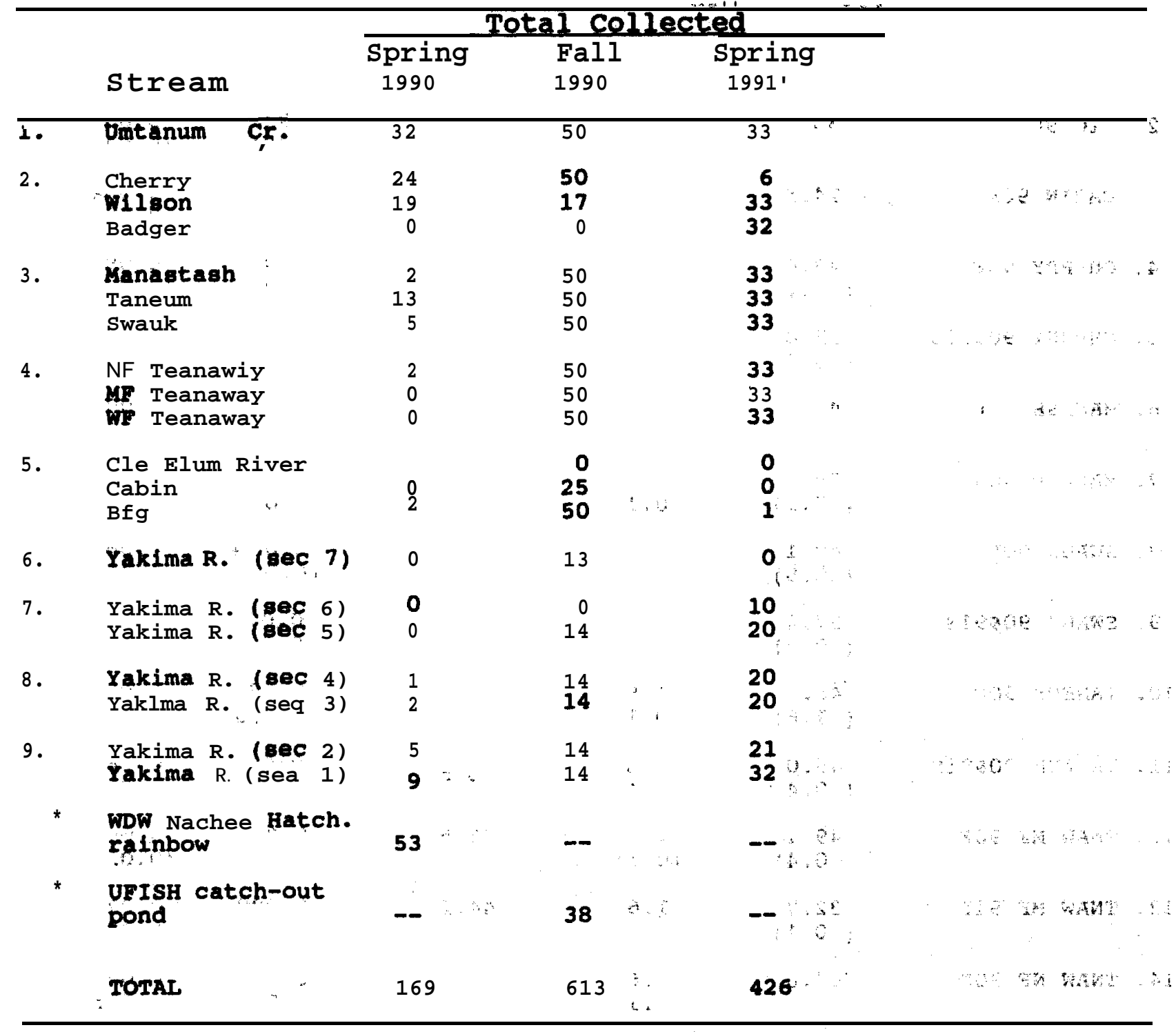

$\therefore:$ 
Table 2. Average heterozygoeity and percentage of loci polymorphic in each collection based on 43 loci (Standard errors in parentheeee).

\begin{tabular}{|c|c|c|c|c|c|c|}
\hline & & & Ma & & Hete & cozygosityy \\
\hline & Collection & $\begin{array}{l}\text { size per } \\
\text { locus }\end{array}$ & $\begin{array}{l}\text { of alleles } \\
\text { per locus }\end{array}$ & $\begin{array}{l}\text { of loci } \\
\text { polymorphic* }\end{array}$ & $\begin{array}{l}\text { Direct-.. } \\
\text { count }\end{array}$ & $\begin{array}{l}\text { Hdywbg } \\
\text { expected** }\end{array}$ \\
\hline 1. & BADGER 91 & $\left(\begin{array}{c}31.5 \\
(0.4)\end{array}\right.$ & $\begin{array}{l}1.4 \\
(0.1)\end{array}$ & 32.6 & $\begin{array}{c}0.099 \\
(0.028)\end{array}$ & $\begin{array}{c}0.094 \\
(0.026)\end{array}$ \\
\hline 2. & BIG 90\&91 & $\begin{array}{c}50.1 \\
(1.2)\end{array}$ & $\begin{array}{l}1.8 \\
(0.2)\end{array}$ & 51.2 & $\begin{array}{c}0.091 \\
(0.022)\end{array}$ & $\begin{array}{c}0.099 \\
(0.024)\end{array}$ \\
\hline 3. & CABIN 90F & $\left(\begin{array}{c}24.5 \\
(0.4)\end{array}\right.$ & $\begin{array}{c}1.5 \\
(0.1)\end{array}$ & 34.9 & $\begin{array}{l}0.084 \\
(0.025)\end{array}$ & $\begin{array}{c}0.044 \\
(0.026)\end{array}$ \\
\hline 4. & CHERRY 90F & $\begin{array}{c}49.6 \\
(0.2)\end{array}$ & $\begin{array}{l}1.7 \\
(0.1)\end{array}$ & 55.8 & $\begin{array}{c}0.089 \\
(0.022)\end{array}$ & $\begin{array}{c}0.095 \\
(0.024)\end{array}$ \\
\hline 5. & CHERRY 90\&91S & $\left(\begin{array}{c}22.8 \\
(0.6)\end{array}\right.$ & $\begin{array}{l}1.6 \\
(0.1)\end{array}$ & 39.5 & $\begin{array}{c}0.098 \\
(0.029)\end{array}$ & $\begin{array}{c}0.091 \\
(0.025)\end{array}$ \\
\hline 6 . & MANASH $90 \mathrm{~F}$ & $\begin{array}{c}48.8 \\
(0.1)\end{array}$ & $\begin{array}{c}1.7 \\
.(0.1)\end{array}$ & 51.2 & $\begin{array}{c}0.087 \\
(0.023)\end{array}$ & $\begin{array}{l}0.090 \\
(0.023)\end{array}$ \\
\hline 7. & MANASH 90\&91S & $\begin{array}{c}34.7 \\
(0.1)\end{array}$ & $\begin{array}{l}1.6 \\
(0.1)\end{array}$ & 37.2 & $\begin{array}{l}0.078 \\
(0.024)\end{array}$ & $\begin{array}{c}0.081 \\
(0.024)\end{array}$ \\
\hline 8. & SWAUK 9OF & $\left(\begin{array}{c}49.1 \\
(0.5)\end{array}\right.$ & $\begin{array}{l}1.8 \\
(0.1)\end{array}$ & 60.5 & $\begin{array}{c}0.084 \\
(0.024)\end{array}$ & $\begin{array}{c}0.088 \\
(0.024)\end{array}$ \\
\hline 9. & SWAUK 90\&91S & $\left(\begin{array}{c}37.4 \\
(0.2)\end{array}\right.$ & $\begin{array}{l}1.7 \\
(0.1)\end{array}$ & 48.8 & $\begin{array}{c}0.078 \\
(0.024)\end{array}$ & $\begin{array}{c}0.087 \\
(0.025)\end{array}$ \\
\hline 10. & TANEUM 90F & $\begin{array}{c}48.5 \\
(1.6)\end{array}$ & $\begin{array}{l}1.5 \\
(0.1)\end{array}$ & 39.5 & $\begin{array}{c}0.082 \\
(0.026)\end{array}$ & $\begin{array}{c}0.077 \\
(0.023)\end{array}$ \\
\hline 11. & TANEUM 90691s & $\left(\begin{array}{c}45.0 \\
0.4)\end{array}\right.$ & $\begin{array}{l}1.6 \\
(0.1)\end{array}$ & 46.5 & $=\begin{array}{c}0.083 \\
(0.025)\end{array}$ & $\begin{array}{l}0.081 \\
(0.023)\end{array}$ \\
\hline 12. & TNAW MF 90F & $\left(\begin{array}{c}49.1 \\
(0.4)\end{array}\right.$ & $\begin{array}{c}1.7 \\
(0.1)\end{array}$ & 46.5 & $\begin{array}{c}0.078 \\
(0.023)\end{array}$ & $\begin{array}{l}0.080 \\
(0.024)\end{array}$ \\
\hline 13. & TNAW MF $91 \mathrm{~s}$ & $\left(\begin{array}{c}32.7 \\
0.1)\end{array}\right.$ & $\begin{array}{c}1.6 \\
(0.1)\end{array}$ & 44.2 & $\begin{array}{c}0.080 \\
(0.026)\end{array}$ & $\begin{array}{c}0.078 \\
(0.024)\end{array}$ \\
\hline 14. & TNAW NF 90F & $\begin{array}{c}49.6 \\
(0.1)\end{array}$ & $\begin{array}{l}1.6 \\
(0.1)\end{array}$ & 48.8 & $\begin{array}{c}0.076 \\
(0.023)\end{array}$ & $\begin{array}{c}0.082 \\
(0.023)\end{array}$ \\
\hline 15 . & TNAW NF 90\&91s & $\left(\begin{array}{c}34.1 \\
0.6)\end{array}\right.$ & $\begin{array}{l}1.7 \\
(0.1)\end{array}$ & 51.2 & $\begin{array}{c}0.091 \\
(0.024)\end{array}$ & $\begin{array}{c}0.092 \\
(0.024)\end{array}$ \\
\hline 16. & TNAW WE 90F & $\begin{array}{c}50.3 \\
(0.2)\end{array}$ & $\begin{array}{c}1.7 \\
(0.1)\end{array}$ & 51.2 & $\begin{array}{c}0.082 \\
(0.027)\end{array}$ & $\begin{array}{c}0.078 \\
(0.024)\end{array}$ \\
\hline 17. & TNAW WF $91 \mathrm{~s}$ & $\begin{array}{c}32.7 \\
(0.1)\end{array}$ & $\begin{array}{l}1.8 \\
(0.2)\end{array}$ & 48.8 & $\begin{array}{c}0.074 \\
(0.023)\end{array}$ & $\begin{array}{c}0.079 \\
(0.024)\end{array}$ \\
\hline 18. & UMTAN 90F & $\begin{array}{c}50.8 \\
\left(\begin{array}{c}0.1 \\
1\end{array}\right)\end{array}$ & $\begin{array}{c}1.8 \\
(0.2)\end{array}$ & 48.8 & $\begin{array}{c}0.106 \\
(0.029)\end{array}$ & $\begin{array}{c}0.104 \\
(0.027)\end{array}$ \\
\hline
\end{tabular}


Table 2 . continued

19. UMTAN 908915

$\begin{array}{lclll}60.0 & 1 & 8 & 62.8 & 0.114 \\ (0.7) & (0.1) & & 0.113 \\ (0.029) & (0.028)\end{array}$

20. WILSON $90 \mathrm{~F}$

$\begin{array}{cc}17.0 & 1.5 \\ 0.0) & (0.1)\end{array}$

0.083
$(0.024)$
0.0 .096

21. WILSON 90\&91S

$\begin{array}{ll}47.4 & 1.8\end{array}$

$(0.6) \quad(0.1)$

22. YAKIMA $790 F$

$-17.2 \quad 1.5$

$\left(\begin{array}{ll}0.2) \quad(0.1) \\ 0\end{array}\right.$

23. YAKIMA 6915
$9.8 \quad 1.6$
$(0.2) \quad(0.1)$

24. YAKIMA 590691

$32.9 \quad 1.8$

25. YAKIMA 490691

$33.5 \quad 1.7$

$$
(0.3) \quad(0.2)
$$

26. YAKIMA 3 90\&91

$\begin{array}{cc}34.8 & 1.8 \\ (0.2) & (0.1)\end{array}$

27. YAKIMA 2 90\&91

$\begin{array}{cc}43.7 & 1.9 \\ (0.2) & (0.2)\end{array}$

28. YAKIMA 1 90\&91

46.7

1.8

$(0.2)$

$(0.2)$

29. GOLDENDALE 90

$\left(\begin{array}{cc}99.1 & 1.4 \\ 0.7\end{array}\right)(0.1)$

30. NACH HAT 90

$\begin{array}{cc}49.8 & 1.4 \\ (1.1) & (0.1)\end{array}$

31. SPOKANE HAT 90

$\begin{array}{ll}98.3 & 1.5 \\ (1.6) & (0.1)\end{array}$

32. S TACOMA HAT 90

$\begin{array}{ll}97.0 & 1.3 \\ (1.6) & (0.1)\end{array}$

$99.1 \quad 1.3$

33. TOKUL HAT 90

10.5

$$
\text { (0.1) }
$$

34. UFISH 90

$$
\begin{gathered}
37.4 \\
(0.5), 1.5 \\
(0.1)
\end{gathered}
$$

55.8

$\therefore \quad(0.023) \quad(0.024)$

$$
\begin{array}{cc}
0.093 & 0.100 \\
(0.023) & (0.024) \\
0.081 & 0.092 \\
(0.022) & (0.025)
\end{array}
$$
$41.9 \quad 0.107-0.112: 17 "$
$\begin{array}{ll}0.107 & 0.112 \\ (0.025) & (0.027)\end{array}$

$58.10 .098^{2} \quad 0.103$. $(0.028) \quad(0.025)$
48.8
0.104
$(0.027)$
0.104

55.8$$
0.106 \quad 0.106
$$

55.8

$(0.024)$

106

55.8

$\begin{array}{cr}0.099 & 0.103 \\ (0.023) & (0.023)\end{array}$

53.5

$\begin{array}{ll}0.104 & 0.197 \\ (0.023) & (0.023)\end{array}$

32.6

$0.085 \quad 0.089$

$(0.025) \quad(0.026)+?$

27.9

0.077

$(0.026)(0.025)$

37.2

0.091

0.084

30.2

$(0.027)$

(0.024)

$0.088 \quad 0.098$ $(0.026) \quad(0.025)$

23.3

0.075 .0075 $(0.025)$ 10.025)

34.9

$0.081: 0087$ $(0.025) \quad(0.027)$

* A locus is considered polymorphic if more than one allele was detected

* Unbiaaed eetimate (see Nei, 1978)

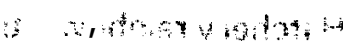


Table 3. Significant deviations of genotype counta from Hardy-Weinberg egulibrium expectations within Yakima River and hatchery rainbow trout coliections.

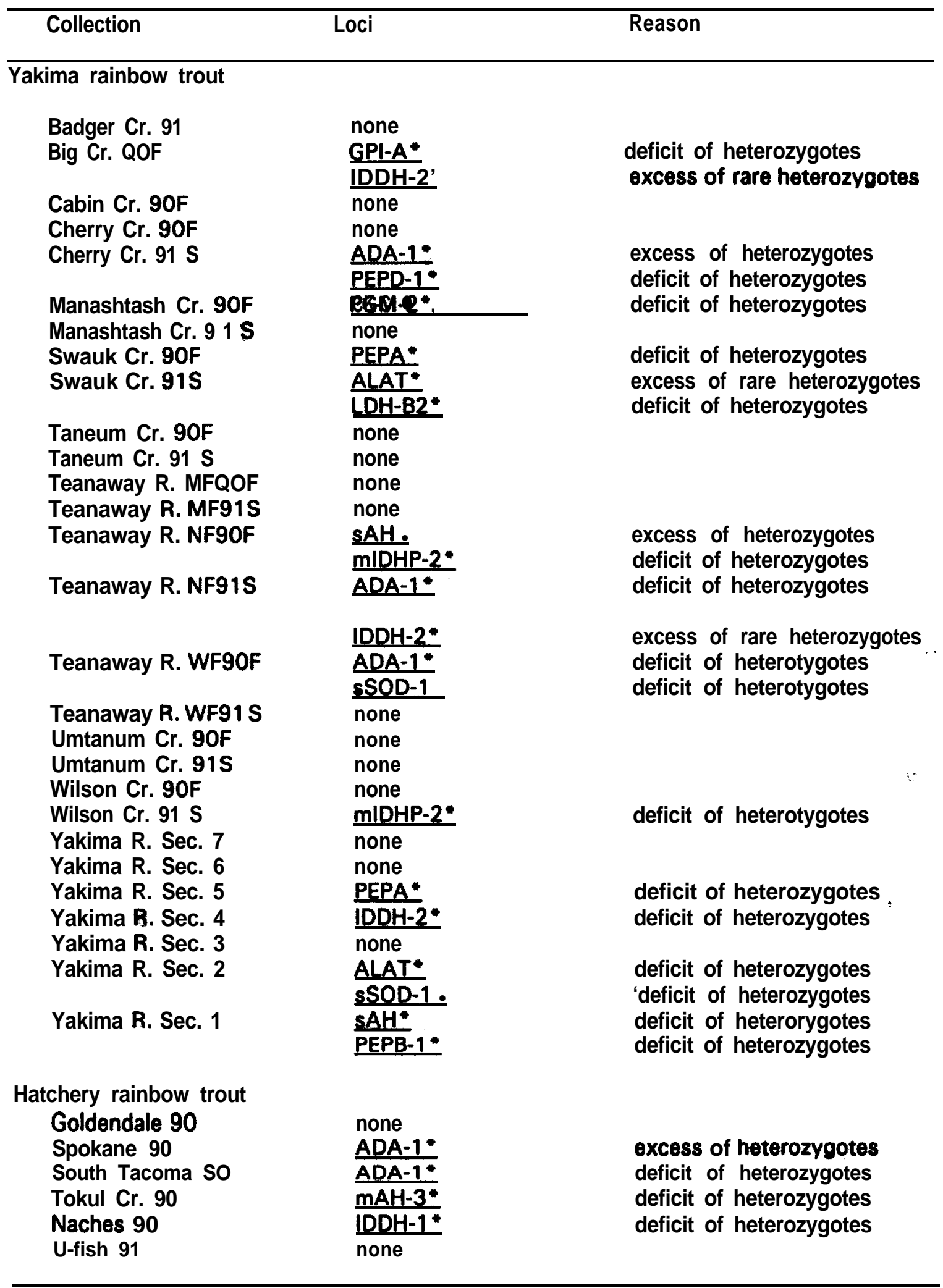


Table 4. Frequencies of selected allề at ten loci that are warkediy drexorent between WDW rainbow trout hatchary stralne and Yakima River collections.

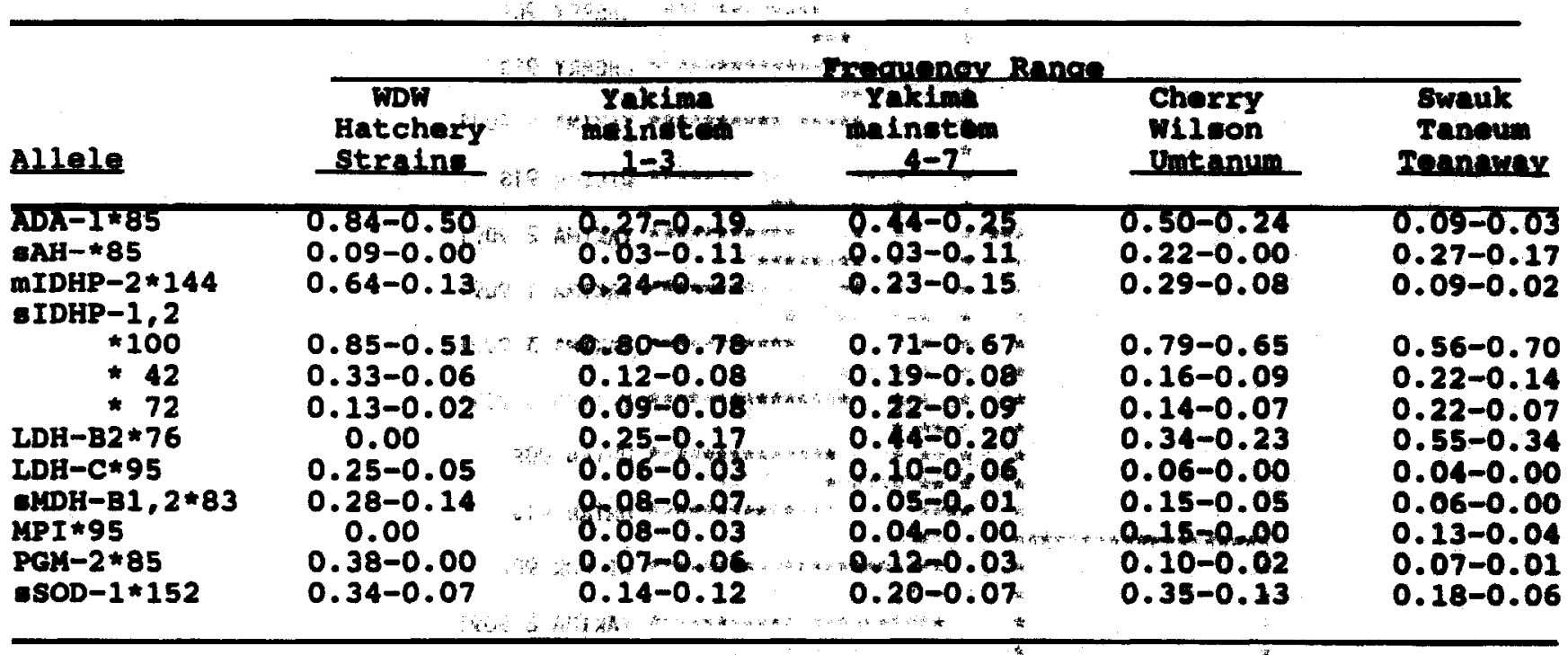

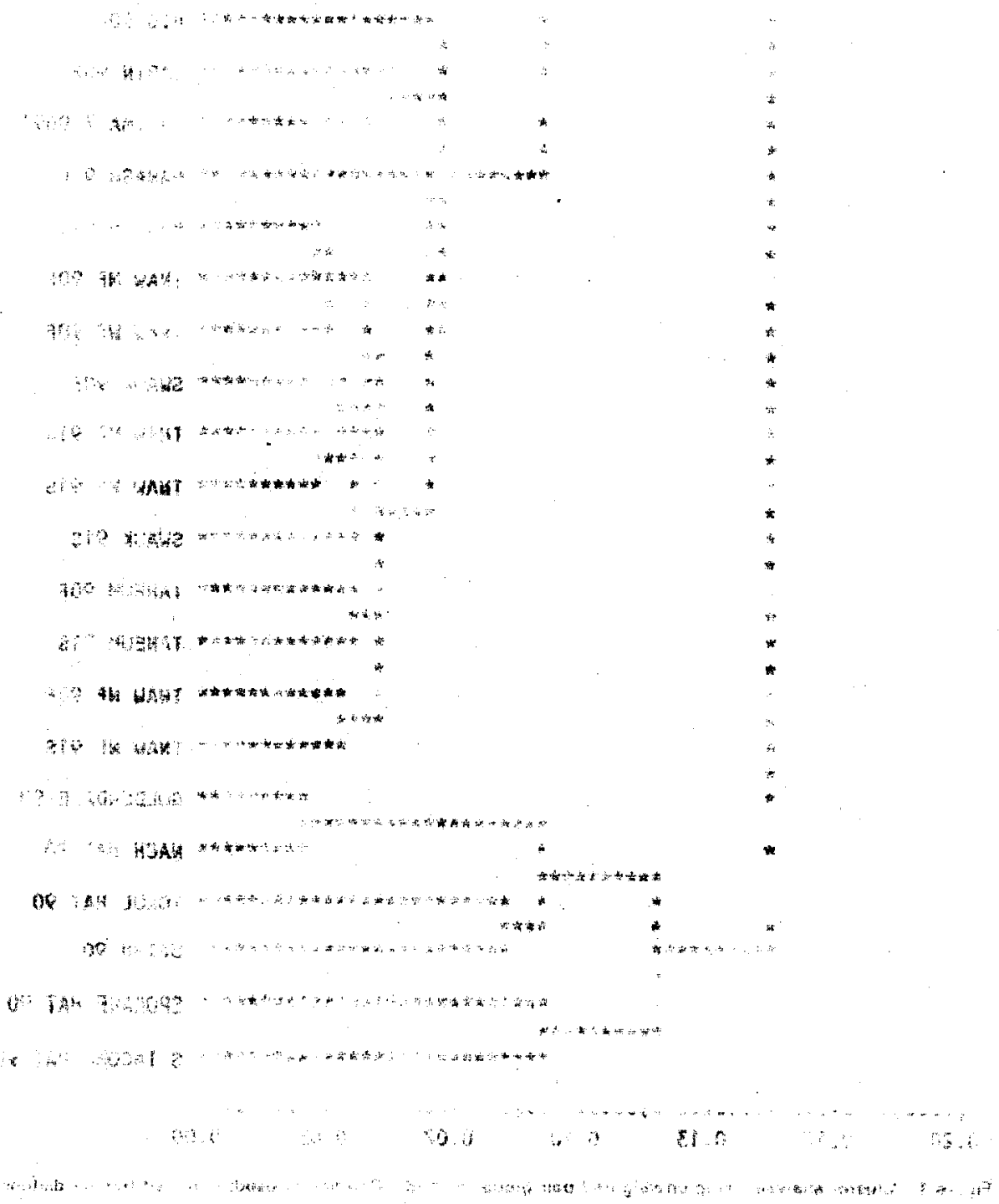


DISTANCE

$0.20 \quad 0.17 \quad 0.13 \quad 0.10 \quad 0.07 \quad 0.03 \quad 0.00$

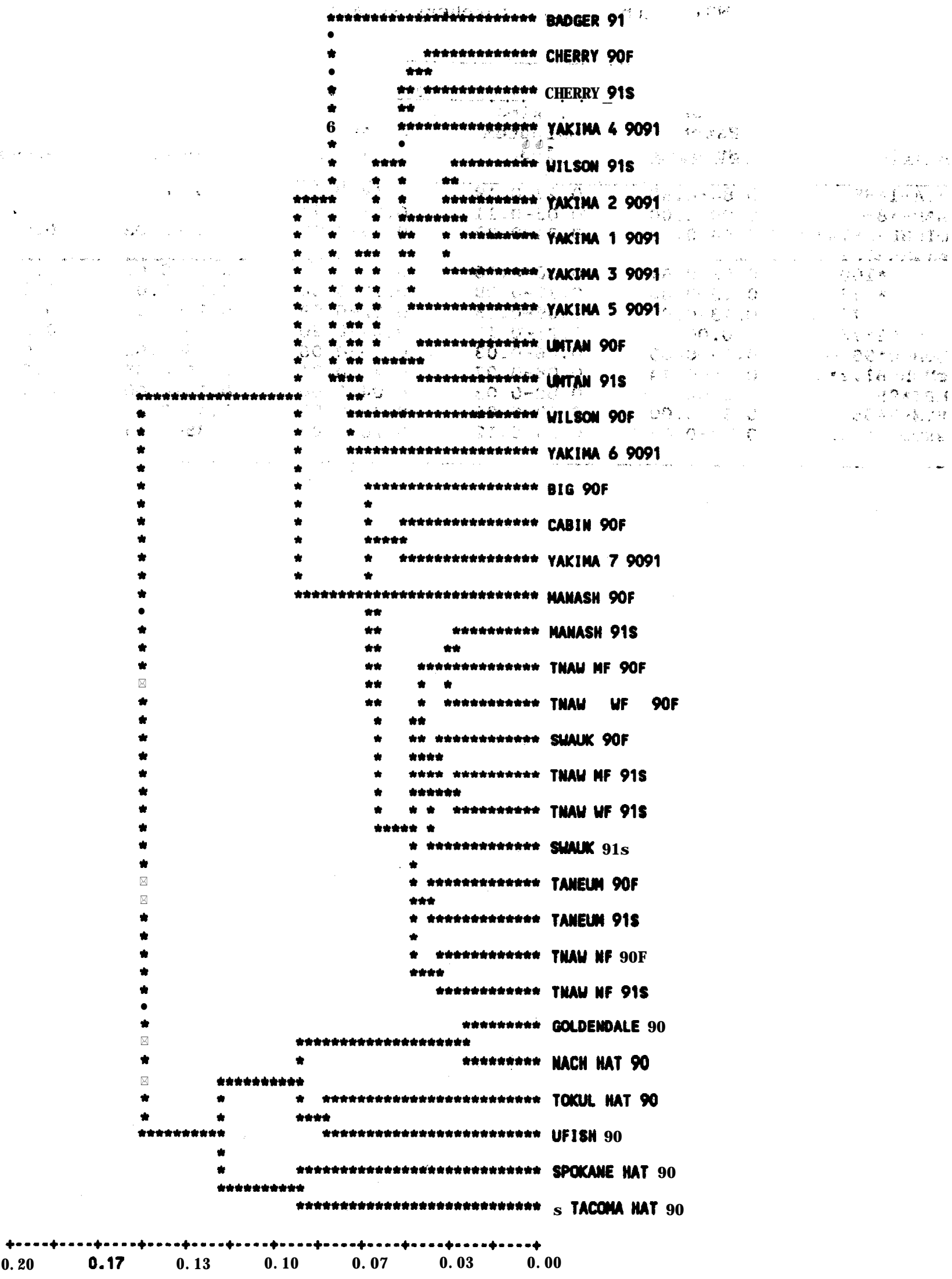

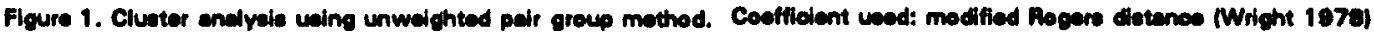




\section{Distauce}

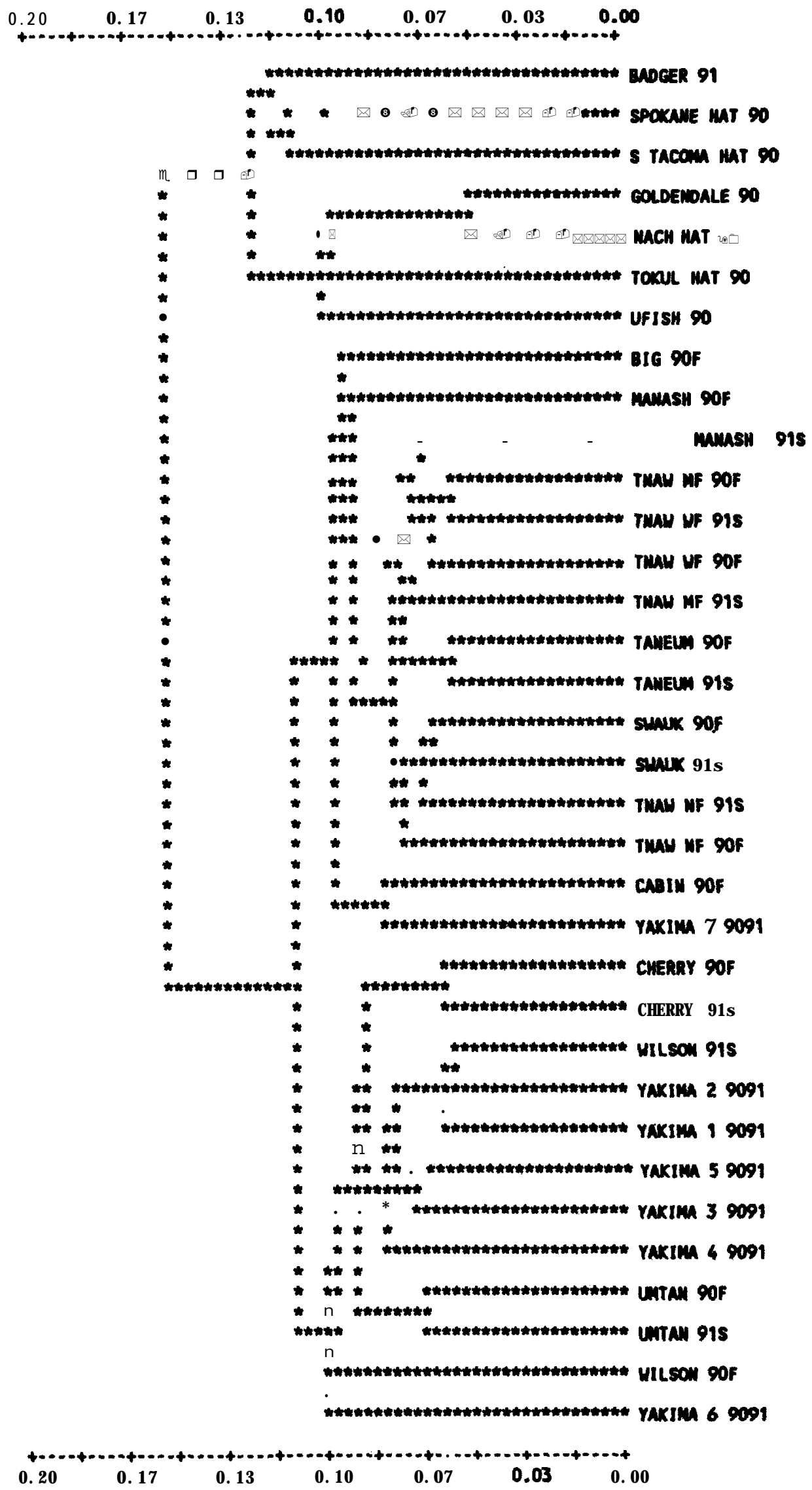

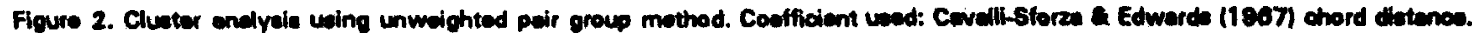

